B Á O C Á O C H U Y Ê $N$ Đ Ê

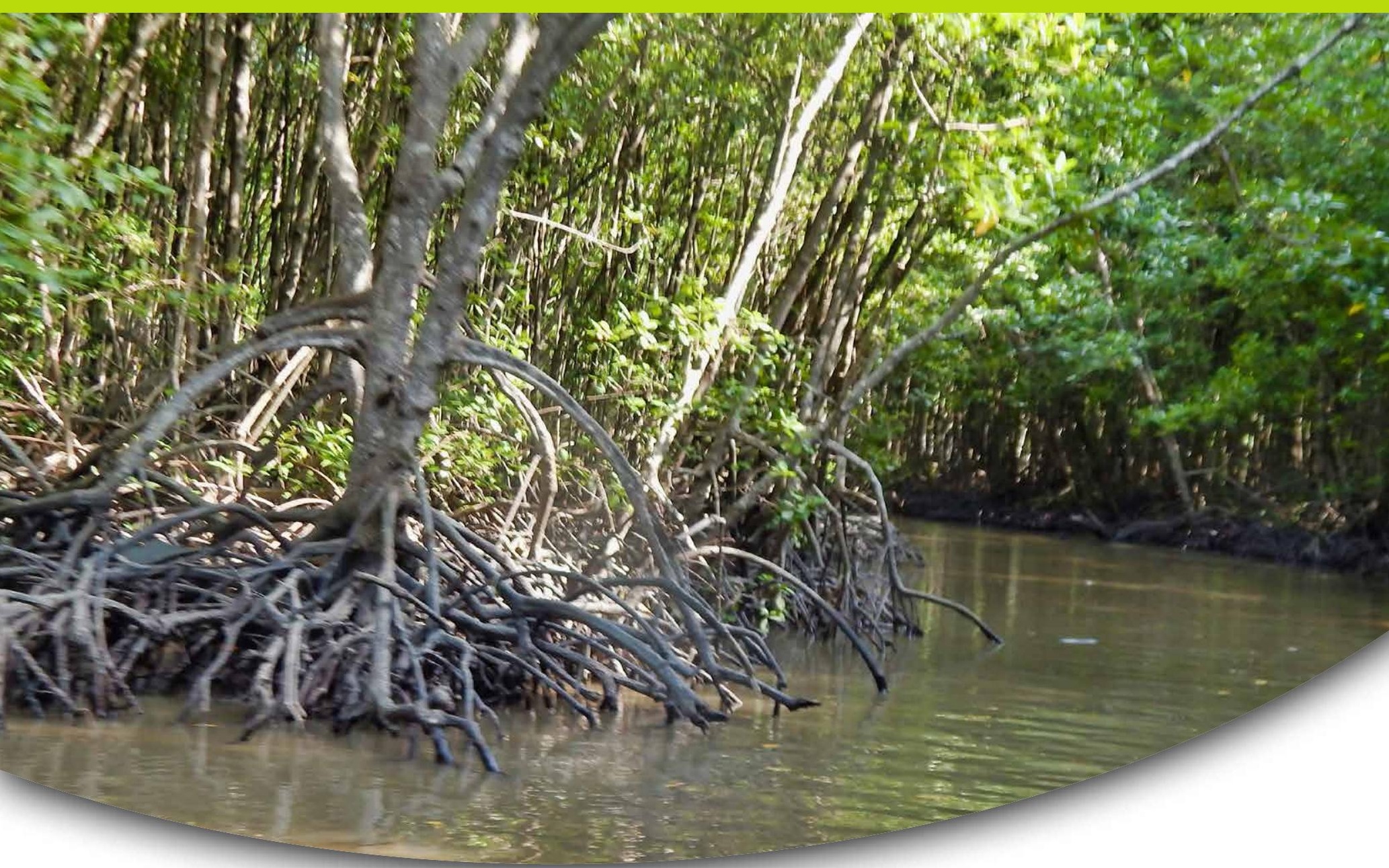

\title{
Người mua và dịch vụ môi trường rừng ngập mặn tiềm năng tại Hải Phòng, Việt Nam
}

Phạm Thu Thủy

Hoàng Tuấn Long

Đào Thị Linh Chi

Ngô Hà Châu
Hoàng Minh Hiếu

Hoàng Thị Uyên

Hoàng Thị Thu Thủy

Nông Nguyễn Khánh Ngọc
Nguyễn Đình Tiến

Trương Văn Vinh

Nguyễn Thành Nho 



\title{
Người mua và dịch vụ môi trường rừng ngập mặn tiềm năng tại Hải Phòng, Việt Nam
}

\author{
Phạm Thu Thủy \\ Trung tâm Nghiên cứu Lâm nghiệp Quốc tế (CIFOR) \\ Hoàng Tuấn Long \\ Trung tâm Nghiên cứu Lâm nghiệp Quốc tế (CIFOR) \\ Đào Thị Linh Chi \\ Trung tâm Nghiên cứu Lâm nghiệp Quốc tế (CIFOR) \\ Ngô Hà Châu \\ Trung tâm Nghiên cứu Lâm nghiệp Quốc tế (CIFOR) \\ Hoàng Minh Hiếu \\ Trung tâm Nghiên cứu Lâm nghiệp Quốc tế (CIFOR) \\ Hoàng Thị Uyên \\ Trung tâm Nghiên cứu Lâm nghiệp Quốc tế (CIFOR) \\ Hoàng Thị Thu Thủy \\ Trung tâm Nghiên cứu Lâm nghiệp Quốc tế (CIFOR) \\ Nông Nguyễn Khánh Ngọc \\ Trung tâm Nghiên cứu Lâm nghiệp Quốc tế (CIFOR) \\ Nguyễn Đình Tiến \\ Trung tâm Nghiên cứu Lâm nghiệp Quốc tế (CIFOR) \\ Trương Văn Vinh \\ Trường Đại học Nông Lâm - TP. HCM (NLU-HCMC) \\ Nguyễn Thành Nho \\ Trường Đại học Nguyễn Tất Thành (NTTU)
}


Báo cáo chuyên đề 206

C 2020 Tổ chức Nghiên cứu Lâm nghiệp Quốc tế (CIFOR)

(c) (i) Nội dung trong ấn phẩm này được cấp quyền bởi Giấy phép bản quyền Ghi nhận công của tác giả - Phi thương mại, không chỉnh sửa, thay đổi hay phát triển - Không phái sinh 4.0. http://creativecommons.org/ licenses/by-nc-nd/4.0/

ISBN 978-602-387-136-0

DOI: $10.17528 /$ cifor/007746

Phạm TT, Hoàng TL, Đào TLC, Ngô HC, Hoàng MH, Hoàng TU, Hoàng TT, Nông NKN, Nguyễn ĐT, Trương VV và Nguyễn TN. 2020. Người mua và dịch vụ môi trường rừng ngập mặn tiềm năng tại Hải Phòng, Việt Nam. Báo cáo chuyên đề 206. Bogor, Indonesia: CIFOR.

Ảnh được chụp bởi: Moira Moeliono/CIFOR

Cảnh quan làng nông thôn Việt Nam

\section{CIFOR}

Jl. CIFOR, Situ Gede

Bogor Barat 16115

Indonesia

$\mathrm{T}+62(251) 8622-622$

$\mathrm{F}+62(251) 8622-100$

E cifor@cgiar.org

\section{cifor.org}

Chúng tôi xin cảm ơn các nhà tài trợ đã hỗ trợ cho nghiên cứu này thông qua việc đóng góp vào quỹ của CGIAR. Xin xem danh sách các nhà tài trợ: http://www.cgiar.org/about-us/our-funders/

Tất cả các quan điểm thể hiện trong ấn phẩm này là của các tác giả. Chúng không nhất thiết đại diện cho quan điểm của CIFOR, các cơ quan chủ quản của tác giả hay của các nhà tài trợ cho ấn phẩm này. 


\section{Mục lục}

Từ viết tắt

Lời cảm ơn $\quad$ viii

Tóm tắt tổng quan — ix

1 Bối cảnh 1

2 Phương pháp nghiên cứu và thu thập số liệu 4

3 Người mua tiềm năng và các dịch vụ môi trường rừng do rừng ngập mặn đem lại 5

3.1 Dịch vụ hấp thụ, lưu trữ, bể chứa các-bon 5

3.2 Dịch vụ giảm bồi lắng và lượng bùn thải 19

3.3 Dịch vụ chống xói lở bờ biển 21

$\begin{array}{ll}3.4 \text { Dịch vụ chắn sóng } & 22\end{array}$

3.5 Dịch vụ cung ứng nước sạch, lọc kim loại nặng và chất ô nhiễm 23

3.6 Dịch vụ cung ứng bãi đẻ 36

3.7 Dịch vụ vẻ đẹp cảnh quan và các dịch vụ liên quan. 36

3.8 Dịch vụ cung cấp nguyên liệu thực phẩm 37

4 Thảo luận và Đề xuất 39

4.1 Thuận lợi và tiềm năng xây dựng cơ chế PFES cho rừng ngập mặn ở Hải Phòng 39

4.2 Tính khả thi của các dịch vụ và cơ chế PFES cho từng dịch vụ 39

4.3 Mở rộng thêm nguồn thu cho bảo vệ rừng ngập mặn trong tương lai 41

$\begin{array}{ll}\text { Tài liệu tham khảo } & 43\end{array}$

Phụ lục $\quad 54$ 


\title{
Danh mục hình, bảng và hộp
}

\author{
Hình \\ 1 Giá trị trung bình của các dịch vụ môi trường rừng ngập mặn đem lại tại Việt Nam 2 \\ 2 Diện tích rừng ngập mặn tại Hải Phòng qua các năm \\ 3 Các loại hình dịch vụ môi trường rừng ngập mặn có thể cung cấp và có thể xây \\ dựng cơ chế PFES tại Việt Nam \\ 4 Người mua tiềm năng cho dịch vụ các-bon \\ 5 Phát thải KNK trong lĩnh vực tiêu thụ năng lượng tại tỉnh Bình Dương 9 \\ 6 Mật độ $\mathrm{CO}_{2}$ trên các phương thức vận tải được chọn, thang Lôga (g/tấn-km) 14 \\ 7 Lượng phát thải khí $\mathrm{CO}_{2}(\mathrm{~g} / \mathrm{tấn}-\mathrm{km})$, Vận tải hàng hoá tuyến đường dài (>150 km), \\ năm 2010 \\ 8 Lượng phát thải khí $\mathrm{CO}_{2}$ đối với vận tải hàng rời tuyến dường dài, năm $2000 \quad 15$ \\ 9 Các bên hưởng lợi từ dịch vụ giảm bồi lắng, nạo vét bùn thải từ RNM 21 \\ 10 Các bên hưởng lợi từ dịch vụ chống xói lở bờ biển của RNM 21 \\ 11 Các bên hưởng lợi từ dịch vụ chắn sóng của RNM 23 \\ 12 Các mô hình khái niệm về các thông số và quá trình vật lý, hoá học, sinh học \\ cho hành vi của vết kim loại \\ 13 Các bên được hưởng lợi từ dịch vụ cung cấp nước sạch và lọc kim loại của RNM 26
}

\section{Bảng}

1 Số lượng người cấp tin chính

2 Tải lượng KNK từ sản xuất công nghiệp tại Bình Dương 2

Các dich vư môi trường rừng cho hoat động khai thác mỏ

4 Dịch vụ môi trường rừng liên quan đến việc khai thác mỏ 11

5 Khai thác khoáng sản 13

6 Tình hình tiến triển của lượng phát thải từ đội tàu VTĐTNĐ ở Việt Nam 16

7 Kết quả thu được từ việc hiện đại hoá và nâng cấp đội tàu 16

8 Kết quả sơ bộ thu được từ chuyển đổi phương thức vận tải hàng hoá từ đường $\begin{array}{ll}\text { bộ sang đường thuỷ } & 16\end{array}$

9 Số lượng cảng tại Hải Phòng 17

10 Các chất ô nhiễm không khí tiềm tàng khi sử dụng thiết bị phun mài khô 18

11 Danh sách các tàu nạo vét Hải Phòng 20

12 Nồng độ chất lơ lửng trong nước 20

13 Độ cao trung bình của sóng trước và sau rừng ngập mặn tại Hải Phòng 22

14 Danh sách các bên xả thải tại các vùng ven biển tại Hải Phòng 25

15 Dự báo nhu cầu than đến năm 2035 
16 Quy hoạch loại, cỡ tàu vận tải theo Quyết định số 1517/QD-TTG ngày 26/08/2014 về phê duyệt quy hoạch phát triển vận tải biển Việt Nam đến năm 2020, định hướng đến năm 2030

17 Phân bổ hàng hóa 2020 và 2030 qua cảng vụ Hải Phòng 28

18 Tác động của việc xây dựng và vận hành cảng biển 30

19 Nguồn và mức độ chất thải rắn 32

20 Tải lượng chất gây ô nhiễm đổ ra biển (Đvt: Nghìn tấn) 32

21 Nồng độ các chất ô nhiễm trong nước vượt quá mức quy định đối với mục đích bảo tồn, mục đích nuôi trồng thủy sản và mục đích khác của các khu vực ven biển và cảng cá Cát Bà thuộc Hải Phòng từ 2005-2011 33

22 Số lượng cơ sở nuôi trồng thuỷ sản tại Hải Phòng 34

24 Tổng hợp số lượng các công ty, doang nghiệp hoạt động trên các lĩnh vực tại Hải Phòng

25 Người mua dịch vụ môi trường tiềm năng đối với RNM tại Việt Nam

Hộp

1 Xây dựng chính sách bồi hoàn hệ sinh thái thông qua hoạt động trồng mới và tái trồng rừng, giảm phá rừng cho ngành khai thác khoáng sản tại Trung Quốc

(Zhang và cộng sự 2010)

2 Cơ chế vận hành và gây quỹ của Quỹ phát triển bền vững khu dự trữ sinh quyển Cát Bà (Khu dự trữ sinh quyển Cát Bà 2020) 


\section{Từ viết tắt}

\begin{tabular}{|c|c|}
\hline ADB & Ngân hàng Phát triển châu Á \\
\hline $\mathrm{Al}_{2} \mathrm{O}_{3}$ & Nhôm oxit \\
\hline Bộ NN-PTNT & Bộ Nông nghiệp và Phát triển Nông thôn \\
\hline $\mathrm{CaO}$ & Canxi oxit \\
\hline CIFOR & Tổ chức Nghiên cứu Lâm nghiệp Quốc tế \\
\hline CNTT & Công nghiệp tàu thủy \\
\hline $\mathrm{CO}$ & Cacbon oxit \\
\hline $\mathrm{CO}_{2}$ & Cacbon dioxit \\
\hline COD & Chemical Oxygen Demand - nhu cầu oxy hóa học \\
\hline $\mathrm{Cr}$ & Crom \\
\hline CTR & Chất thải rắn \\
\hline $\mathrm{Cu}$ & Đồng \\
\hline DN & Doanh nghiệp \\
\hline DRC & Cộng hòa Dân chủ Congo \\
\hline DTSQ & Dự trữ sinh quyển \\
\hline DWT & Tổng trọng tải \\
\hline Ef & Hệ số phát thải \\
\hline EVN & Tập đoàn Điện lực Việt Nam \\
\hline $\mathrm{FeO}$ & Sắt oxit \\
\hline FEU & 40 foot tương đương với 2 công-ten-nơ tiêu chuẩn 20 ft \\
\hline GCS-REDD+ & Dự án Nghiên cứu so sánh toàn cầu \\
\hline GHCP & Giới hạn cho phép \\
\hline GHG & Khí nhà kính \\
\hline GPP & Tổng năng suất sơ cấp \\
\hline IMO & Tổ chức Hàng hải Quốc tế \\
\hline IUCN & Liên minh Bảo tồn Thiên nhiên Quốc tế \\
\hline KKT & Khu kinh tế \\
\hline KLN & Kim loại nặng \\
\hline KNK & Khí nhà kính \\
\hline MARPOL & Công ước quốc tế về ngăn ngừa ô nhiễm từ tàu \\
\hline $\mathrm{Mg}$ & Megagam \\
\hline $\mathrm{MgO}$ & Magie oxit \\
\hline $\mathrm{MnO}$ & Mangan (II) Oxit \\
\hline MPA & Khu bảo tồn biển \\
\hline Mục địch BT & Mục đích bảo tồn \\
\hline MW & Megawatt \\
\hline NĐ-CP & Nghị định Chính phủ \\
\hline NEE & Trao đổi các-bon ròng của hệ sinh thái \\
\hline NEP & Năng suất ròng của hệ sinh thái \\
\hline $\mathrm{NO} 2$ & Nito dioxit \\
\hline NTTS & Nuôi trồng thủy sản \\
\hline OECD & Tổ chức Hợp tác và Phát triển Kinh tế \\
\hline
\end{tabular}




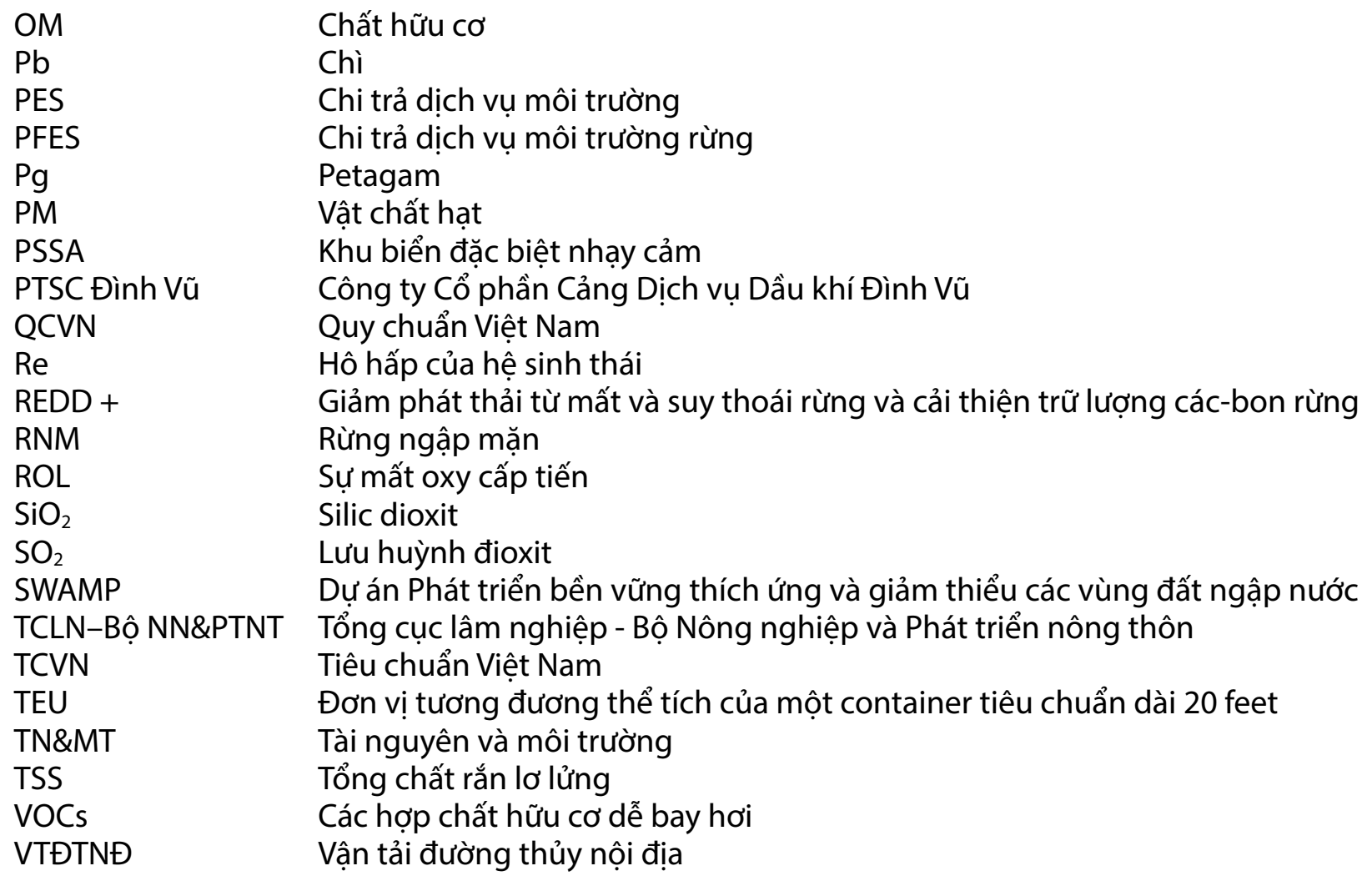




\section{Lời cảm ơn}

Báo cáo này là sản phẩm của hai dự án: Nghiên cứu so sánh toàn cầu (GCS-REDD+) và Chương trình Thích ứng và Giảm thiểu các vùng đất ngập nước bền vững (SWAMP) do NORAD và USAID cùng hỗ trợ tài chính. Chúng tôi xin chân thành cảm ơn sự hỗ trợ quý báu của ông Lê Văn Thanh và ông Nguyễn Chiến Cường - Quỹ Bảo vệ và Phát triển Rừng Việt Nam đã hỗ trợ nghiên cứu này. Chúng tôi cũng xin chân thành cảm ơn những chuyên gia và nhiều cá nhân đã nhiệt tình tham gia trong suốt quá trình thực hiện dự án. 


\section{Tóm tắt tổng quan}

Tầm quan trọng về sinh thái, môi trường và kinh tế của rừng ngập mặn đã được công nhận rộng rãi trên toàn thế giới và được giới khoa học trong và ngoài nước chứng minh với các số liệu ở các quy mô và vùng sinh thái khác nhau. Tuy nhiên, diện tích rừng ngập mặn đang giảm dân trên toàn cầu. Hiện nay, bảo vệ và mở rộng diện tích rừng ngập mặn đã trở thành một ưu tiên chính trong nhiều chính sách biến đổi khí hậu, xóa đói giảm nghèo và chính sách phát triển lâm nghiệp tại Việt Nam. Tuy nhiên, việc bảo vệ và phát triển rừng ngập mặn tại Việt Nam còn gặp rất nhiều khó khăn, đặc biệt là ngân sách và nguồn tài chính thực hiện công tác này còn hạn hẹp. Chính sách chi trả dịch vụ môi trường rừng (PFES) của Việt Nam, dù mới chỉ được thực hiện từ năm 2010, đã trở thành một trong những nguồn thu lớn nhất của ngành lâm nghiệp. Chính sách chi trả dịch vụ môi trường rừng tại Việt Nam (PFES) có quy định chi trả cho dịch vụ môi trường rừng ngập mặn thông qua dịch vụ nuôi trồng thủy sản và cung ứng bãi đẻ. Tuy nhiên, việc thực hiện PFES đối với dịch vụ môi trường này còn hạn chế và việc chỉ tập trung vào dịch vụ nuôi trông thủy sản và cung ứng bãi đẻ đã bỏ qua những tiềm năng to lớn khác rừng ngập mặn có thể đem lại.

Việc đánh giá tiềm năng chi trả dịch vụ môi trường do rừng ngập mặn đem lại đang trở nên vô cùng cấp thiết bởi điều này sẽ giúp nâng cao tổng thu PFES và nhận thức của các bên có liên quan về giá trị to lớn mà rừng ngập mặn đem lại cho các ngành nghề kinh tế, từ đó bảo vệ rừng ngập mặn hiệu quả hơn. Mặc dù vậy, xây dựng cơ chế chi trả dịch vụ môi trường rừng cho các dịch vụ khác ngoài dịch vụ cung ứng bãi đẻ hiện nay gặp nhiều khó khăn do thiếu các thông tin liên quan đến việc "Chi trả cho dịch vụ nào? Ai là người chi trả? Mức chi trả là bao nhiêu? Thu chi như thế nào?" Việc trả lời 4 câu hỏi trên đòi hỏi phải có nhiều nghiên cứu được tiến hành bài bản trong một thời gian đủ dài.

Báo cáo này nhằm trả lời cho 2 câu hỏi đầu tiên dựa vào trường hợp nghiên cứu điểm tại Hải Phòng. Báo cáo cho thấy Cơ chế chi trả dịch vụ môi trường rừng (PFES) đối với rừng ngập mặn tại Việt Nam có thể áp dụng với 8 loại dịch vụ môi trường chính: 1) Dịch vụ hấp thụ, lưu trữ, bể chứa các-bon; 2 ) Dịch vụ giảm bồi lắng và lượng bùn thải; 3) Dịch vụ chống xói lở bờ biển; 4) Dịch vụ chắn sóng; 5) Dịch vụ cung ứng nước sạch, lọc kim loại nặng và chất ô nhiễm; 6) Dịch vụ cung ứng bãi đẻ; 7) Dịch vụ vẻ đẹp cảnh quan; và 8) Dịch vụ cung cấp nguyên liệu thực phẩm. Kết quả nghiên cứu cũng chỉ rõ có 20 nhóm người mua dịch vụ môi trường rừng ngập mặn tiềm năng trên địa bàn Hải Phòng bao gồm: Công ty doanh nghiệp nạo vét, công ty năng lượng, ngành giải trí, ngành ngân hàng, ngành vận tải hàng không, cảng cá, cảng biển, khu kinh tế ven biển, công ty khai thác cát, ngành khai thác khoáng sản và luyện kim, ngành vận tải, ngành nhiệt điện, các nhóm quản lí đê điều, công ty du lịch, cộng đông dân cứ, công nghiệp đóng tàu, công ty sản xuất mặt hàng nông, lâm, thủy hải sản, công ty xăng dầu và công ty nước sạch. Trong khi một số nhóm người mua đã thể hiện cam kết cao cho việc tiến hành chi trả (vd: ngân hàng, năng lượng, công ty sản xuất các sản phẩm nông, lâm, thủy hải sản), cần có thêm nhiều nghiên cứu trong tương lai để tìm hiểu mức sẵn lòng chi trả của các bên còn lại trong việc tham gia PFES. 



\section{Bối cảnh}

Tầm quan trọng về sinh thái, môi trường và kinh tế của rừng ngập mặn đã được công nhận rộng rãi trên toàn thế giới và được giới khoa học trong và ngoài nước chứng minh với các số liệu ở các quy mô và vùng sinh thái khác nhau. Trong báo cáo gần đây, Ủy ban Thích ứng Khí hậu Toàn cầu (The Global Adaptation Commission) cũng nhấn mạnh rằng lợi ích từ việc bảo vệ và tái sinh rừng ngập mặn (ví dụ từ thủy sản, lâm nghiệp, cảnh quan sinh thái và giảm thiểu rủi ro) có thể gấp 10 lần so với chi phí bỏ ra (Global Commission on Adaptation 2019). Kết quả rà soát về định lượng giá trị kinh tế của một số dịch vụ môi trường mà rừng ngập mặn đem lại trên quy mô cả nước cho thấy tổng giá trị trung bình của dịch vụ môi trường rừng ngập mặn tại Việt Nam có thể lên tới 4213.19 USD/ha (Hình 1).

Dù có vai trò rất quan trọng, diện tích rừng ngập mặn tại Việt Nam đang có nhiều nguy cơ bị biến mất trước biến đổi khí hậu, chính sách và thực tiễn quản lí và bảo vệ rừng ngập mặn chưa hiệu quả (Phạm và cộng sự 2019). Trước bối cảnh này, việc bảo vệ và phát triển rừng ngập mặn đang trở thành một trong những ưu tiên hàng đầu của Việt Nam.

Chính sách chi trả dịch vụ môi trường rừng tại Việt Nam (PFES) được triển khai trên quy mô toàn quốc từ năm 2010 và từ đó đã trở thành một nguồn tài chính chủ lực cho ngành lâm nghiệp. PFES đã quy định chi trả cho dịch vụ môi trường rừng ngập mặn thông qua dịch vụ nuôi trồng thủy sản và cung ứng bãi đẻ. Tuy nhiên, việc thực hiện chi trả đối với dịch vụ này còn gặp nhiêu khó khăn và còn chưa xem xét

1 Trong báo cáo này, dấu phẩy được dùng để phân cách hàng nghìn và dấu chấm được dùng để phân cách phần thập phân. đến nhiều dịch vụ tiềm năng khác của rừng ngập mặn mà các học giả trên thế giới đã đề cập đến bao gồm (i) Phòng hộ ven biển giảm tác động của sóng, gió và thiên tai, (ii) tạo cảnh quan du lịch, (iii) hấp thụ và là bể chứa các bon, (iv) duy trì nguồn lợi thủy hải sản của khu vực, nơi sống và làm tổ của động vật, bảo tồn đa dạng sinh học, (v) duy trì và ổn định đường bờ, bãi biển, tạo bãi bồi, chống sụt lún bởi quá trình xói lở tự nhiên, (vi) hỗ trợ sinh kế cho địa phương thông qua việc cung cấp gỗ, nhiên liệu, thực phẩm, dược liệu, nguyên liệu xây dựng, (vii) là nơi tham quan, giáo dục, nghiên cứu, và (viii) lọc và làm sạch nước, điều tiết khí hậu (Nguyễn và Nguyễn 2014, Bandaranayake 1998, Mumby và cộng sự 2004; Pham và cộng sự 2018).

Việc đánh giá tiềm năng chi trả dịch vụ môi trường do rừng ngập mặn đem lại đang trở nên vô cùng cấp thiết bởi điều này sẽ giúp nâng cao tổng thu PFES và nhận thức của các bên có liên quan về giá trị to lớn mà rừng ngập mặn đem lại cho các ngành nghề kinh tế, từ đó bảo vệ rừng ngập mặn hiệu quả hơn. Mặc dù vậy, xây dựng cơ chế chi trả dịch vụ môi trường rừng cho các dịch vụ khác ngoài dịch vụ cung ứng bãi đẻ hiện nay gặp nhiều khó khăn do thiếu các thông tin liên quan đến việc "Chi trả cho dịch vụ nào? Ai là người chi trả? Mức chi trả là bao nhiêu? Thu chi như thế nào?" Việc trả lời 4 câu hỏi trên đòi hỏi phải có nhiều nghiên cứu được tiến hành bài bản trong một thời gian đủ dài. Trong khuôn khổ chương trình dự án SWAMP (Chương trình Thích ứng và Giảm thiểu các vùng đất ngập nước bền vững) do USAID tài trợ (2018-2020) và dự án Nghiên cứu so sánh toàn cầu về REDD+ (GCS-REDD+) do NORAD tài trợ, CIFOR đã tiến hành nghiên cứu điểm tại Hải Phòng với mong muốn trả lời 4 câu hỏi đặt ra và xây dựng đề xuất chính sách để có thể hình thành cơ chế chi trả mới cho các 


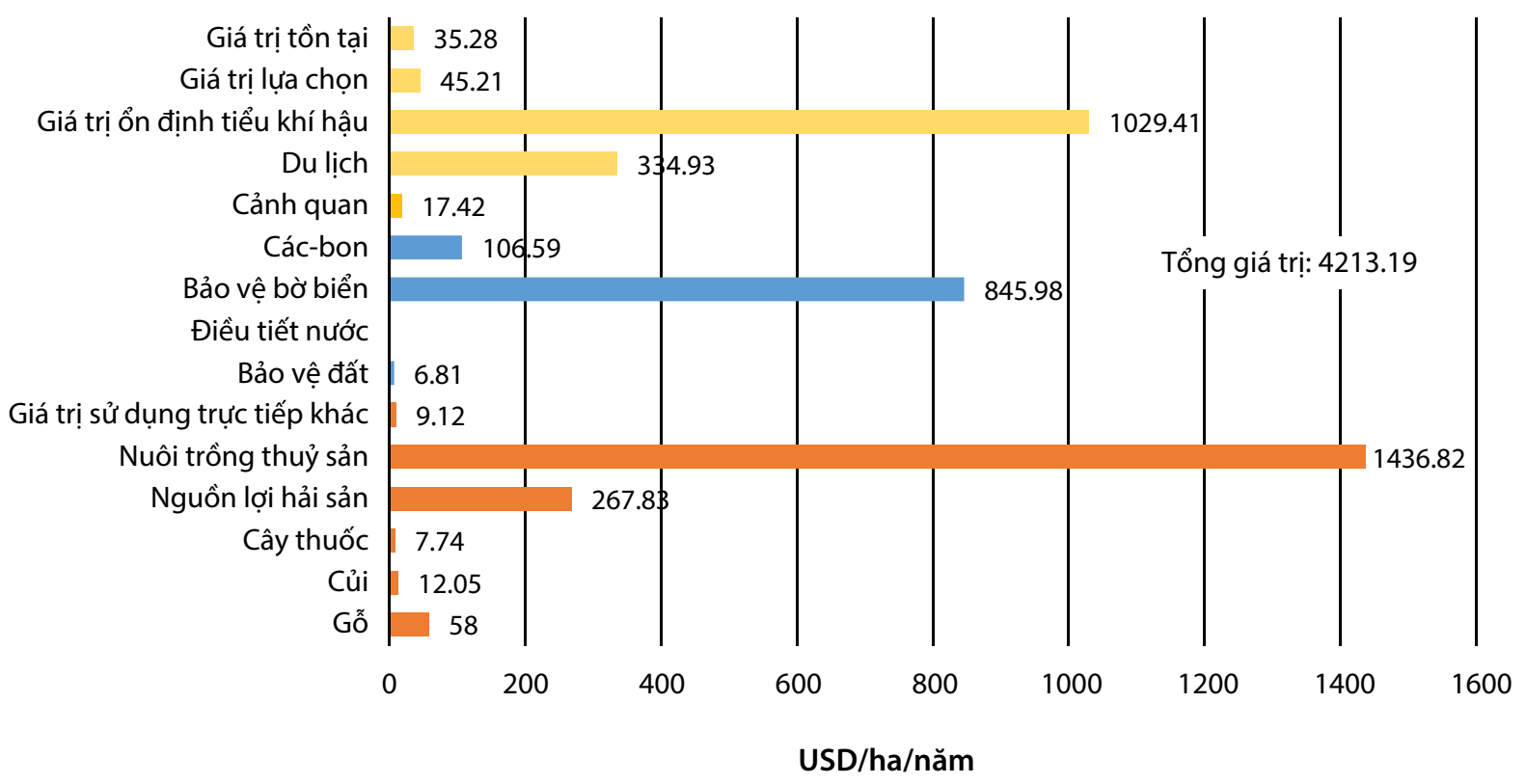

Hình 1. Giá trị trung bình của các dịch vụ môi trường rừng ngập mặn đem lại tại Việt Nam Nguồn: nhóm tác giả vẽ dựa trên số liệu thu thập được từ Phạm và cộng sự 2019

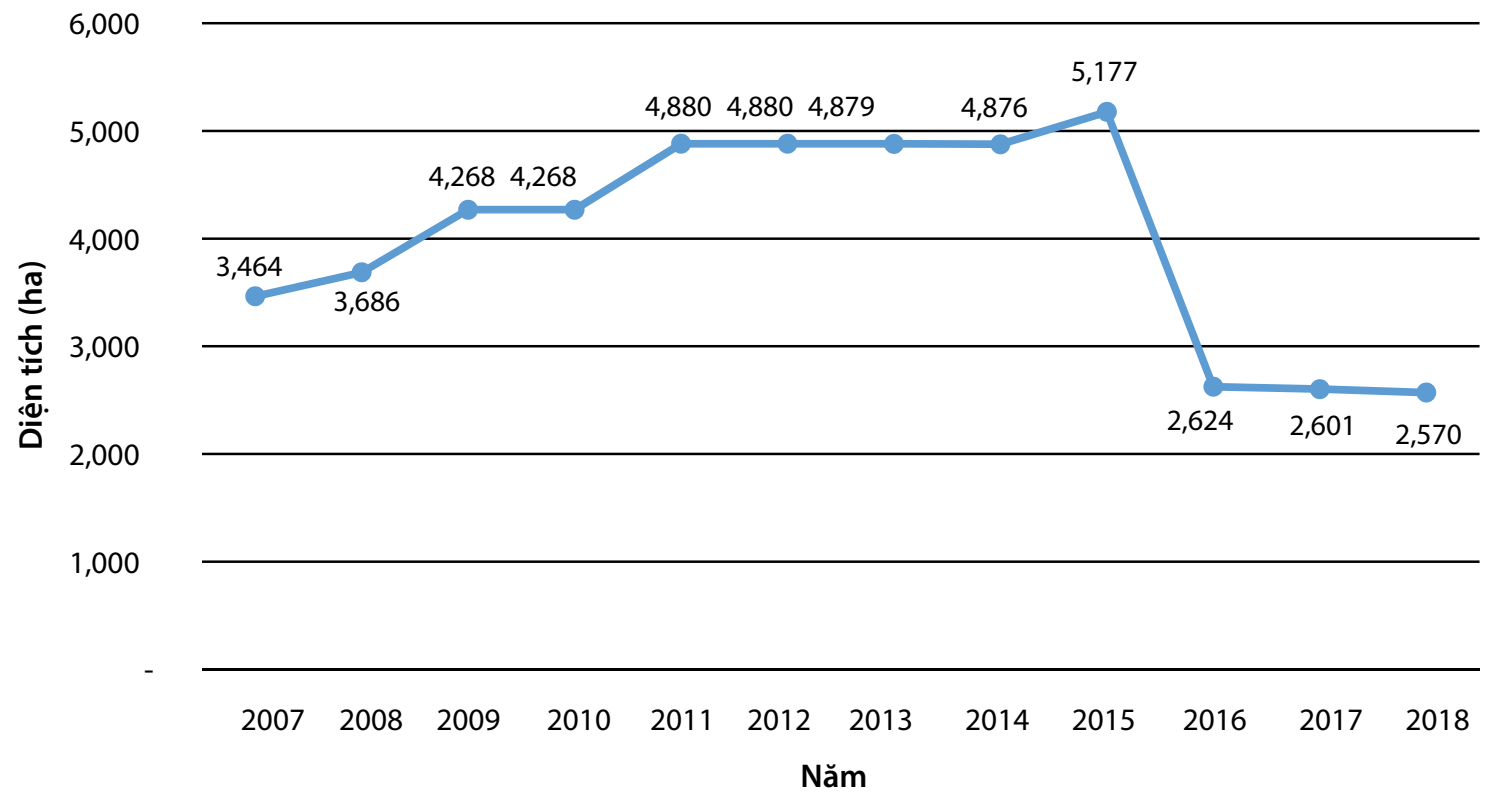

Hình 2. Diện tích rừng ngập mặn tại Hải Phòng qua các năm

Nguồn: Nhóm tác giả tổng hợp từ số liệu của TCLN - Bộ NN\&PTNT 
dịch vụ môi trường đa dạng mà rừng ngập mặn đem lại. Đầu ra của dự án là 3 sản phẩm:

- Báo cáo 1. Xác định dịch vụ và người chi trả tiềm năng

- Báo cáo 2. Xác định mức chi trả và cơ chế thu chi

- Báo cáo 3. Báo cáo khuyến nghị chính sách về PFES cho rừng ngập mặn tại Việt Nam dựa trên tổng hợp Báo cáo 1 , Báo cáo 2 , và các tham vấn chính sách phản biện của bên có liên quan

Báo cáo này là Báo cáo 1 của dự án. Nhóm nghiên cứu chọn thành phố Hải Phòng làm nghiên cứu điểm bởi nhiều lí do:

- Diện tích rừng ngập mặn tại Hải Phòng đang chịu nhiều áp lực từ yêu cầu phát triển kinh tế của thành phố và có xu thế giảm mạnh từ năm 2015 cho tới nay (Hình 2).

- Hải Phòng là cảng biển lớn nhất tại miền Bắc Việt Nam cũng như có tiềm năng phát triển kinh tế biển vượt trội so với các tỉnh lân cận. Tại Hải Phòng có đầy đủ các nhóm người sử dụng dịch vụ môi trường rừng cần khảo sát như du lịch sinh thái, sản xuất nuôi trồng thủy hải sản, cảng cá và cảng biển, vận chuyển và khai thác khoáng sản.
- Tại Hải Phòng có nhiều nhóm người mua dịch vụ môi trường rừng đã trả tiền để bảo vệ rừng ngập mặn một cách tự nguyện như Công ty Năng lượng Stadtwerke Münster của Đức, ngân hàng Standard Charter và nhiều doanh nghiệp khác trên địa bàn. Điều này minh chứng cho tiềm năng dịch vụ mà rừng ngập mặn đem lại cũng như mối quan tâm của người mua đối với dịch vụ môi trường này.

- Nghiên cứu này đi đúng định hướng phát triển kinh tế bền vững mà Hải Phòng đã đề ra. Hải Phòng đã có nhiều chính sách nhấn mạnh cam kết chính trị về việc phát triển đi đôi với bảo tồn, đặc biệt là đối với Khu dự trữ sinh quyển Cát Bà. Cát Bà/Hải Phòng hiện đang được đánh giá là vùng biển đặc biệt nhạy cảm (PSSA) theo hướng dẫn của Tổ chức Hàng hải quốc tế (IMO). Để đáp ứng được các tiêu chí PSSA do IMO đề ra, Hải Phòng cần bảo tồn các giá trị sinh thái và giảm thiểu các hoạt động hàng hải có ảnh hưởng xấu đến môi trường (Cục Hàng hải Việt Nam 2015). Điều này cho thấy nhiều thuận lợi về mặt cam kết chính trị cũng như hành lang pháp lí cho việc hỗ trợ hình thành cơ chế chi trả cho dịch vụ môi trường rừng ngập mặn tại Hải Phòng. 


\section{Phương pháp nghiên cứu và thu thập số liệu}

Để xác định dịch vụ mới và người chi trả tiềm năng cho các dịch vụ môi trường rừng do rừng ngập mặn đem lại, nhóm nghiên cứu đã sử dụng nhiều phương pháp kết hợp.

Nghiên cứu tài liệu thứ cấp. Các tài liệu nghiên cứu về vai trò và tiềm năng của rừng ngập mặn, các dịch vụ môi trường rừng ngập mặn, các báo cáo của cơ quan nhà nước, các doanh nghiệp, các tổ chức dân sự xã hội, các bài học kinh nghiệm trong xây dựng cơ chế chi trả dịch vụ môi trường rừng trong và ngoài nước được rà soát và phân tích kĩ lưỡng.

Phỏng vấn sâu. 52 cuộc phỏng vấn đã được thực hiện với các bên có liên quan (Bảng 1). Mục đích của các cuộc phỏng vấn này nhằm tìm hiểu quan điểm của các bên về:

- Vai trò, tầm quan trọng, và đóng góp của rừng ngập mặn đối với từng ngành nghề và các bên có liên quan;

- Xác định người mua của từng dịch vụ môi trường rừng mà hiện nay rừng ngập mặn đang cung cấp ở Hải Phòng;

- Mức sẵn lòng chi trả của các bên để bảo vệ và phát triển rừng ngập mặn;

- Cơ hội và thách thức trong việc bảo vệ và phát triển rừng ngập mặn;

- Cơ hội và thách thức trong việc thực hiện chi trả dịch vụ môi trường rừng ngập mặn.
Việc thu thập số liệu về dịch vụ và người mua tiềm năng được thực hiện từ tháng 1-9 năm 2019.

Bảng 1. Số lượng người cấp tin chính

\begin{tabular}{lc}
\hline Người phỏng vấn & Số lượng \\
\hline $\begin{array}{l}\text { Sở Nông nghiệp và Phát Triển Nông } \\
\text { Thôn Hải Phòng }\end{array}$ & 2 \\
\hline $\begin{array}{l}\text { Quỹ phát triển bền vững khu dự trự } \\
\text { sinh quyển Cát Bà }\end{array}$ & 1 \\
\hline Vườn Quốc Gia Cát Bà & 3 \\
\hline Quỹ Phát triển bảo vệ rừng Cát Bà & 2 \\
\hline $\begin{array}{l}\text { Chi cục Kiểm lâm Hải Phòng/Quỹ Bảo vệ } \\
\text { và Phát triển rừng Hải Phòng }\end{array}$ & 2 \\
\hline Chi cục Thủy sản Hải Phòng & 3 \\
\hline UBND xã Phù Long & 2 \\
\hline Hộ nuôi trồng thủy hải sản xã Phù Long & 2 \\
\hline Công ty du lịch, khách sạn & 20 \\
\hline Chuyên gia khoa học & 3 \\
\hline Cán bộ quản lí bến tàu, bến phà & 4 \\
\hline Cán bộ quản lí bến cảng & 3 \\
\hline Nhà máy nước & 1 \\
\hline Công ty chế biến thực phẩm, đồ uống & 1 \\
\hline Công ty than & 1 \\
\hline Công ty xử lý bùn công ty thoát nước & 1 \\
\hline Nhà máy xử lý chất thải rắn & 1 \\
\hline Tổng số & 52 \\
\hline
\end{tabular}




\section{Người mua tiềm năng và các dịch vụ môi trường rừng do rừng ngập mặn đem lại}

Kết quả nghiên cứu tài liệu thứ cấp từ trong và ngoài nước cho thấy việc xây dựng cơ chế chi trả dịch vụ môi trường rừng (PFES) có thể được tiến hành với 8 loại dịch vụ chính mà rừng ngập mặn đem lại (Hình 3).

Từng loại dịch vụ môi trường rừng được liệt kê trong Hình 3, và tiềm năng người mua dịch vụ trong bối cảnh của thành phố Hải Phòng sẽ được thảo luận dần trong các phần dưới đây.

\subsection{Dịch vụ hấp thụ, lưu trữ, bể chứa các-bon}

Rừng đóng vai trò đặc biệt quan trọng trong chu trình các-bon toàn cầu, đặc biệt là rừng ngập mặn (RNM). Với dòng đời dài và khả năng lưu giữ các-bon lâu bền, khả năng lưu trữ cácbon của rừng ngập mặn cao hơn so với các hệ sinh thái khác. Nhiều nghiên cứu đã chỉ ra rằng lượng các-bon RNM lưu trữ có thể cao hơn từ 3-4 lần so với rừng nhiệt đới trên cạn (Alongi 2012). Tại nhiều quốc gia như Indonesia, rừng ngập mặn lưu trữ 3.14 tỉ tấn các-bon, đóng góp 1/3 lượng các-bon lưu trữ của toàn hệ sinh thái ven bờ trên toàn cầu. Nghiên cứu trên toàn cầu về lưu trữ và hấp thụ các-bon của rừng ngập mặn cũng cho thấy cứ mỗi hectare rừng ngập mặn bị phá đi sẽ phát thải khoảng 450 Mg các-bon mỗi hectare. Điều này có nghĩa là 1-hectare rừng ngập mặn bị mất tương đương với 3-5 hectare rừng nhiệt đới trên cạn bị mất (Sasmito và cộng sự 2019). Nhiều nghiên cứu toàn cầu khác được tiến hành bởi CIFOR cũng cho thấy rừng ngập mặn là một trong những kiểu rừng có trữ lượng các-bon cao nhất tại vùng nhiệt đới, chứa bình quân 1,023 Mg cácbon trên mỗi hectare. Đất giàu chất hữu cơ phân bố tại độ sâu từ $0.5 \mathrm{~m}$ đến $3 \mathrm{~m}$ dưới mặt đất và chiếm tới 49-98\% trữ lượng các-bon trong các hệ sinh thái này và việc phá rừng ngập mặn sẽ phát thải 0.02-0.12 Pg các-bon

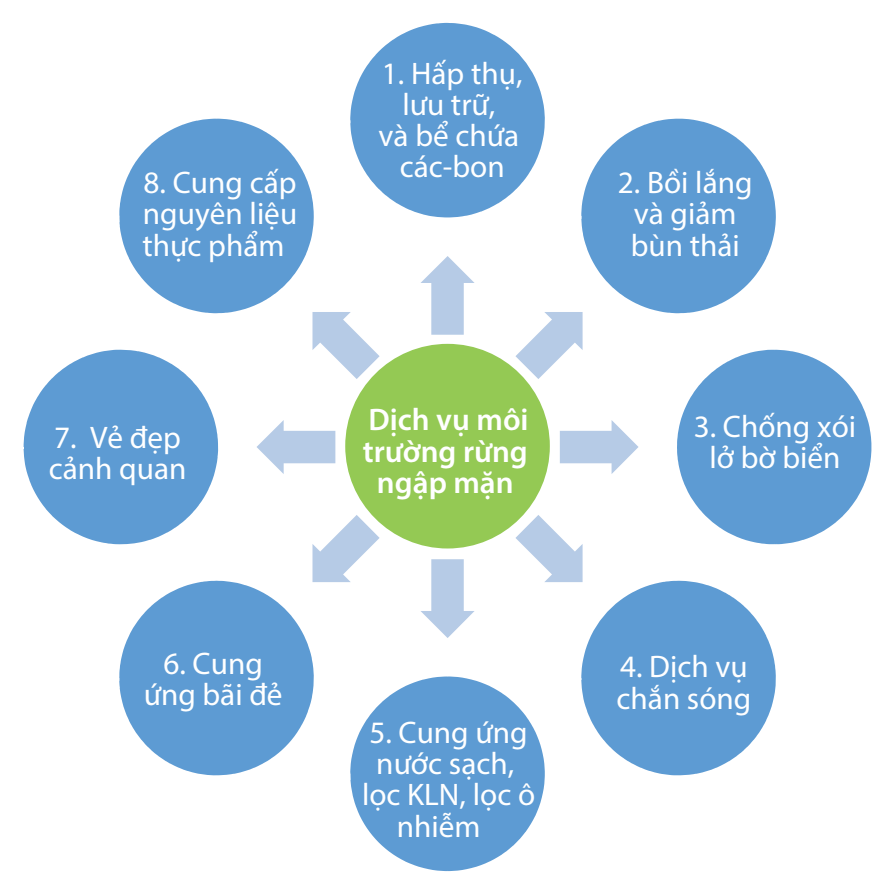

Hình 3. Các loại hình dịch vụ môi trường rừng ngập mặn có thể cung cấp và có thể xây dựng cơ chế PFES tại Việt Nam

Nguồn: Nhóm tác giả 2020

mỗi năm - chiếm khoảng 10\% lượng phát thải do phá rừng toàn cầu dù diện tích rừng ngập mặn chỉ chiếm $0.7 \%$ tổng diện tích rừng nhiệt đới (Donato và cộng sự 2012).

Do sinh trưởng trong môi trường yếm khí, quá trình phân huỷ một lượng lớn sinh khối là vật rụng và rễ chết diễn ra chậm, nên phần lớn lượng các-bon lưu trũ của hệ sinh thái RNM nằm trong đất. Khối lượng các-bon được lưu trữ trong đất rừng ngập mặn tùy thuộc vào loại hình rừng, tuổi rừng, độ sâu của tầng đất, lịch sử địa chất, mức độ bị tác động, kiểu chất nền, các đặc điểm thủy văn và một số yếu tố khác. Theo Donato và cộng sự (2011), lượng các-bon hấp thụ bình quân 972 tấn/ha ở vùng cửa sông 
và 792 tấn/ha ở vùng biển, phần lớn là các-bon hữu cơ được tích luỹ trong đất chứ không phải từ sinh khối của rễ ngầm. Điều này cho thấy lượng các-bon tích luỹ trong hệ sinh thái RNM là của một quá trình tích luỹ lâu dài hàng chục đến hàng trăm năm. Khi tính toán về dịch vụ các-bon (hấp thụ hoặc bể chứa), cần phải làm rõ các vấn đề sau với người mua:

Tính đủ giữa khả năng tích luỹ các-bon của rừng ngập mặn ở các bộ phận sinh khối cũng như lượng vật rụng tích luỹ trong tầng đất, định lượng phát thải khí nhà kính vào khí quyển trong quá trình sinh trưởng của RNM.

Cần chứng minh hệ sinh thái RNM là bể chứa các-bon (carbon sink) hay là nguồn phát thải các-bon (carbon source). Sự cân bằng các-bon của hệ sinh thái RNM được biểu thị bằng năng suất ròng của hệ sinh thái (NEP) và trao đổi cácbon ròng của hệ sinh thái (NEE). Để xác định NEE chính là sự cân bằng giữa hô hấp của hệ sinh thái (Re) với tổng năng suất sơ cấp (GPP), sự cân bằng này có thể là âm (RNM lúc này là bể chứa) hoặc là dương (RNM lúc này là nguồn phát thải).

Tuy nhiên, câu hỏi đặt ra trong bối cảnh của Hải Phòng là ai sẽ là người mua tiềm năng cho dịch vụ các-bon này? Theo kết quả phỏng vấn với Chi cục kiểm lâm và Quỹ Bảo vệ và Phát triển rừng Hải Phòng, trong thời gian vừa qua đã có rất nhiều công ty, cá nhân và doanh nghiệp

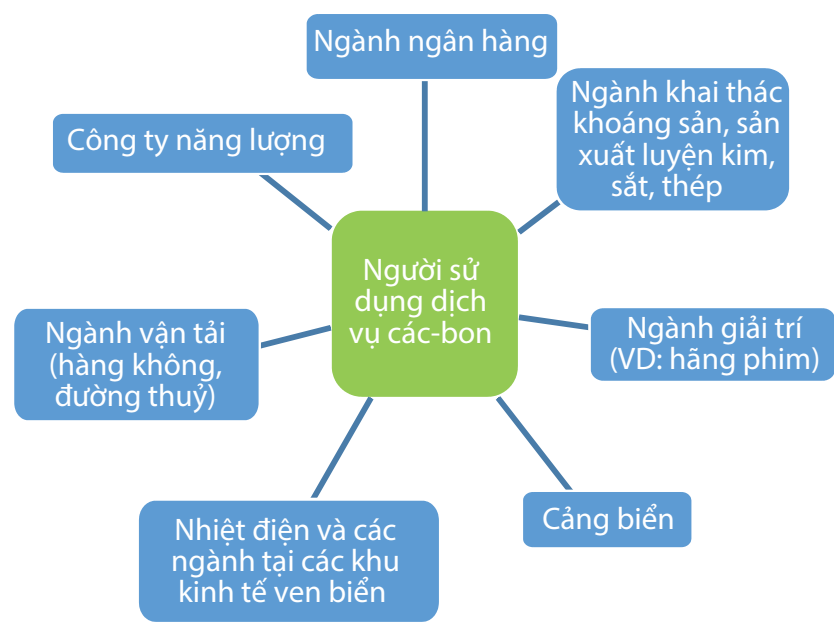

\section{Hình 4. Người mua tiềm năng cho dịch vụ các-bon}

nước ngoài liên hệ với hai cơ quan này để tìm diện tích và giải pháp phát triển rừng ngập mặn. Phần lớn các công ty này đều nhắm đến dịch vụ hấp thụ các-bon và do vậy yêu cầu hai cơ quan này hướng dẫn và cho đề xuất để xây dựng các dự án trồng rừng và tái sinh rừng có chu kì lâu dài. Điều này cho thấy dịch vụ cácbon trong thực tế đang là nhu cầu của nhiều nhóm người mua dịch vụ môi trường rừng (Giri và cộng sự 2011; Van der Werf và cộng sự 2009).

Kết quả rà soát tài liệu thứ cấp và khảo sát thực địa tại Hải Phòng cũng cho thấy, hiện có 6 nhóm người mua cho dịch vụ các-bon của rừng ngập mặn (Hình 4).

\subsubsection{Nhiệt điện và các ngành kinh tế tại khu kinh tế (KKT) ven biển}

Khu kinh tế ven biển: Ban quản lý các khu kinh tế (KKT) ven biển tính toán vào năm 2010, tổng lượng phát thải khí $\mathrm{CO}_{2}$ của các KKT ven biển thuộc các lĩnh vực phát triển kinh tế như công nghiệp, nông nghiệp, dịch vụ, tính chung là trên 7.42 triệu tấn (tương đương bình quân 4.06 tấn $\mathrm{CO}_{2}$ phát thải trên một đầu người) với lượng phát thải chủ yếu là từ các nhà máy nhiệt điện. Dự báo đến năm 2020, sẽ có 39 nhà máy nhiệt điện hoạt động tại các KKT ven biển, trong đó 15 nhà máy sản xuất điện (SXĐ) phương án cao với tổng công suất 16,629 MW, 13 nhà máy SXĐ theo phương án trung bình với tổng công suất 11,678 MW và 11 nhà máy SXĐ theo phương án thấp với tổng công suất 9,767 MW. Vi thế, các nhà máy nhiệt điện tại KKT ven biển dự tính sẽ có mức độ phát thải khí nhà kính rất lớn, gấp 11.09 lần đối với phương án SXĐ cao, gấp 7.54 lần đối với phương án SXĐ trung bình và gấp 5.76 lần đối với phương án SXĐ thấp vào năm 2020 (Dương 2018). Việc phát thải khí nhà kính gây ra bởi các nhà máy thủy điện và các ngành kinh tế trong KKT ven biển đã gây ảnh nưởng nặng nề tới điều kiện và chất lượng sống của người dân ven biển. Các chuyên gia Cục Khí tượng Thủy văn và Biến đổi khí hậu (Bộ Tài nguyên và Môi trường) cho rằng, để giảm phát thải khí nhà kính, đi đôi với đổi mới công nghệ nhằm giảm thiểu khí nhà kính trong các khu kinh tế ven biển, trong những năm tới, Việt Nam cần tiếp tục xây dựng, hoàn thiện cơ chế, chính sách, giải pháp giảm phát thải khí nhà kính cho từng lĩnh vực phát triển kinh tế trong các khu kinh tế ven biển, trong đó đặc biệt chú trọng đến các ngành, lĩnh vực 
gây nhiều phát thải. Một trong chính sách đó có thể là cơ chế chi trả dịch vụ môi trường rừng với việc thu phí dịch vụ môi trường rừng đối với các nhà máy nhiệt điện và các ngành nghề kinh tế trong KKT ven biển (Dương 2018).

Dự án khu công nghiệp: Tại Hải Phòng, khoảng $30 \%$ GDP toàn thành phố được đóng góp bởi nền kinh tế biển và cũng khoảng $30 \%$ GDP kinh tế biển - ven biển của cả nước đến từ Hải Phòng, nơi có tốc độ tăng trưởng kinh tế biển cao hơn tốc độ tăng trưởng chung của vùng ven biển của cả nước. So với năm 2011, thành phố có thêm 5 dự án khu công nghiệp với diện tích 1,760 ha nâng tổng số khu công nghiệp được cấp giấy chứng nhận đầu tư lên 16 dự án với tổng diện tích là 5,695 ha (Trần và Đỗ 2018). Trong đó, có một số dự án điển hình như Khu kinh tế Đình Vũ - Cát Hải, Khu đô thị mới Bắc Sông Cấm, Khu đô thị công nghiệp và dịch vụ VSIP Hải Phòng, Khu công nghiệp Nam Đình Vũ, ... , các dự án phát triển dịch vụ du lịch vui chơi giải trí như Khu du lịch và nghỉ dướng cao cấp Hòn Dấu, Khu du lịch quốc tế Đồi Rồng, Khu vui chơi, giải trí nhà ở và công viên sinh thái đảo Vũ Yên (Vinhomes 2019). Các khu công nghiệp, kinh tế biển đã tập trung thu hút lượng lớn vốn đầu tư, công nghệ; đẩy nhanh sản xuất, kim ngạch xuất khẩu, phát triên kinh tế, mở rộng liên kết vùng tới các tỉnh phía Nam và Tây nam Trung Quốc ... Đến năm 2017, Hải Phòng đã được đầu tư 11.4 tỷ USD với 242 dự án FDI trong đó Nhật Bản đứng đầu về số lượng còn Hàn Quốc đứng đầu về quy mô và vốn (Trần và Đỗ 2018).

Logistic: Hiện nay, có khoảng 20 trung tâm logistics đang hoạt động tại Hải Phòng nhưng phần lớn là quy mô nhỏ, chỉ phục vụ được một hoặc một vài doanh nghiệp hay chỉ tham gia hạn chế vài hoạt động trong chuỗi logistics. Chính vì thế đến năm 2020, trong giai đoạn đầu thực hiện quy hoạch, Hải Phòng sẽ có 4 trung tâm logistics được hoàn thành, đặt mục tiêu tổng lượng hàng hóa đạt khoảng 71.6 triệu tấn/ năm (trong đó đạt 4.01 triệu TEU/năm), tương đương 40-50\% tổng lượng hàng có nhu cầu dịch vụ vận tải trên địa bàn thành phố. Hiện nay lượng hàng hóa điều phối bởi các trung tâm logistics của Hải Phòng còn rất thấp nên đây là bước tiến nổi bật của thành phố trong quá trình tăng trưởng logistics quốc gia (Mai 2019).
Theo Quyết định 821/QĐ-TTg của Thủ tướng Chính phủ ngày 06 tháng 07 năm 2018 về Phê duyệt điều chỉnh, bổ sung quy hoạch tổng thể phát triển kinh tế - xã hội thành phố Hải Phòng đến năm 2025, định hướng đến 2030, trung tâm dịch vụ Logistics sẽ nằm tại Khu công nghiệp Nam Đình Vũ với 4 trung tâm Logistics vệ tinh là: Lạch Huyện, VSIP, Tràng Duệ và Tiên Lãng (Thủ tướng Chính Phủ 2018).

Nhiệt điện: Nhóm nghiên cứu đã xác định được có 2 nhà máy nhiệt điện là nhà máy nhiệt điện Hải Phòng 1 và nhà máy nhiệt điện Hải Phòng 2 thuộc Công ty cổ phần nhiệt điện Hải Phòng với công suất 600MW (Cục điều tiết điện lực 2015). Đến 2018, Hải Phòng đã gộp lại chỉ còn 1 nhà máy nhiệt điện Hải Phòng với công suất 1200MW (Cục điều tiết điện lực 2017). Với tốc độ phát triển nhanh chóng của các khu công nghiệp kinh tế ven biển tại Hải Phòng và mức độ phát thải khí nhà kính ngày càng tăng, các doanh nghiệp hoạt động tại khu kinh tế, đặc biệt là các nhà máy nhiệt điện, sẽ là người sử dụng dịch tiềm năng cho dịch vụ hấp thu các-bon mà rừng ngập mặn đem lại.

\subsubsection{Sản xuất luyện kim, gang thép, khai thác khoáng sản}

Ngành công nghiệp nặng sản xuất gang thép tiềm ẩn và chứa đựng nhiều nguy cơ và các yếu tố độc hại. Quá trình sản xuất gang thép phát sinh nhiều nguồn chất thải gồm nước thải, khí bụi thải và chất thải rắn (Nghiêm và Bùi 2016). Theo số liệu thống kê, cứ mỗi tấn thép thô sản xuất bằng công nghệ lò cao sẽ phải thải ra hơn $500 \mathrm{~kg}$ chất thải rắn (xỉ), $3 \mathrm{~m}^{3}$ nước thải độc hại, $10,000 \mathrm{~m}^{3}$ khí thải, $100 \mathrm{~kg}$ bụi, 2.3 tấn $\mathrm{CO}_{2}$ cùng các loại khí độc khác như $\mathrm{CO}, \mathrm{SO}_{2}$ và bụi kim loại (Nguyễn và Nguyễn 2017). Đặc biệt, một lượng lớn các chất thải gây ô nhiễm môi trường và một lượng bụi lên tới hàng nghìn tấn/năm, chủ yếu là các oxit kim loại và những loại oxit khác (FeO, $\mathrm{MnO}, \mathrm{Al}_{2} \mathrm{O}_{3}, \mathrm{SiO}_{2}, \mathrm{CaO}, \mathrm{MgO}$ ) và các loại khí thải $\left(\mathrm{CO}, \mathrm{CO}_{2}, \mathrm{SO}_{2}, \mathrm{NO}_{2}\right)$, được tạo ra trong quá trình sản xuất gang thép gây ảnh hưởng nghiêm trọng tới sức khỏe của con người (Nghiêm và Bùi 2016).

Theo một số nghiên cứu tại tỉnh Sơn Tây, Trung Quốc, phát thải khí độc hại $\mathrm{SO}_{2}$ của các doanh nghiệp khai thác khoáng sản là 329,700 tấn/ năm, khói bụi tạo ra là 448,200 tấn/năm, chiếm 
khoảng $32 \%-51.5 \%$ ô nhiễm trên địa bàn toàn tỉnh gây ảnh hưởng nghiêm trọng đến sức khỏe cộng đồng (CCICED 2006). Kết quả nghiên cứu tại Bình Dương (Sở Khoa học và Công nghệ Bình Dương 2014) cũng cho thấy Ngành công nghiệp với 24 nhóm ngành (khai khoáng, chế biến thực phẩm, giấy và các sản phẩm từ giấy, nhựa và cao su, khoáng phi kim, sản xuất kim loại...) đã phát thải một lượng khí nhà kính là 7.29 triệu tấn $\mathrm{CO}_{2}$ tương đương/năm, trong đó ngành sản xuất kim loại và khoáng phi kim có mức phát thải cao nhất là $24.06 \%$ và $27.5 \%$ (Bảng 2).

Nguồn gốc phát thải từ 2 ngành này chủ yếu là quá trình đốt nhiên liệu hóa thạch, tiêu thụ điện năng và một số công đoạn sản xuất đặc trưng của ngành như nấu chảy, đúc, gia công kim loại. Như vậy, tại Bình Dương, theo các số liệu tính toán, trong các ngành kinh tế, lượng KNK phát sinh cao nhất đối với ngành sản xuất kim loại và khoáng phi kim (3.7 triệu tấn $\mathrm{CO}_{2}$ tương đương/năm) (Hình 5).

Hiện nay các doanh nghiệp khai thác quặng, sản xuất thép phải đóng một số thuế, phí và lệ phí như thuế bảo vệ môi trường Số: 57/2010/ QH12 (Quốc hội Việt Nam 2010) với biểu phí theo Nghị quyết số: 579/2018/UBTVQH14 (Ủy ban Thường vụ Quốc hội 2018) trong đó, khi thu mua, nhập khẩu than thì sẽ phải đóng thuế từ 15,000-30,000/tấn và phải đóng phí bảo

\section{Bảng 2. Tải lượng KNK từ sản xuất công nghiệp tại Bình Dương}

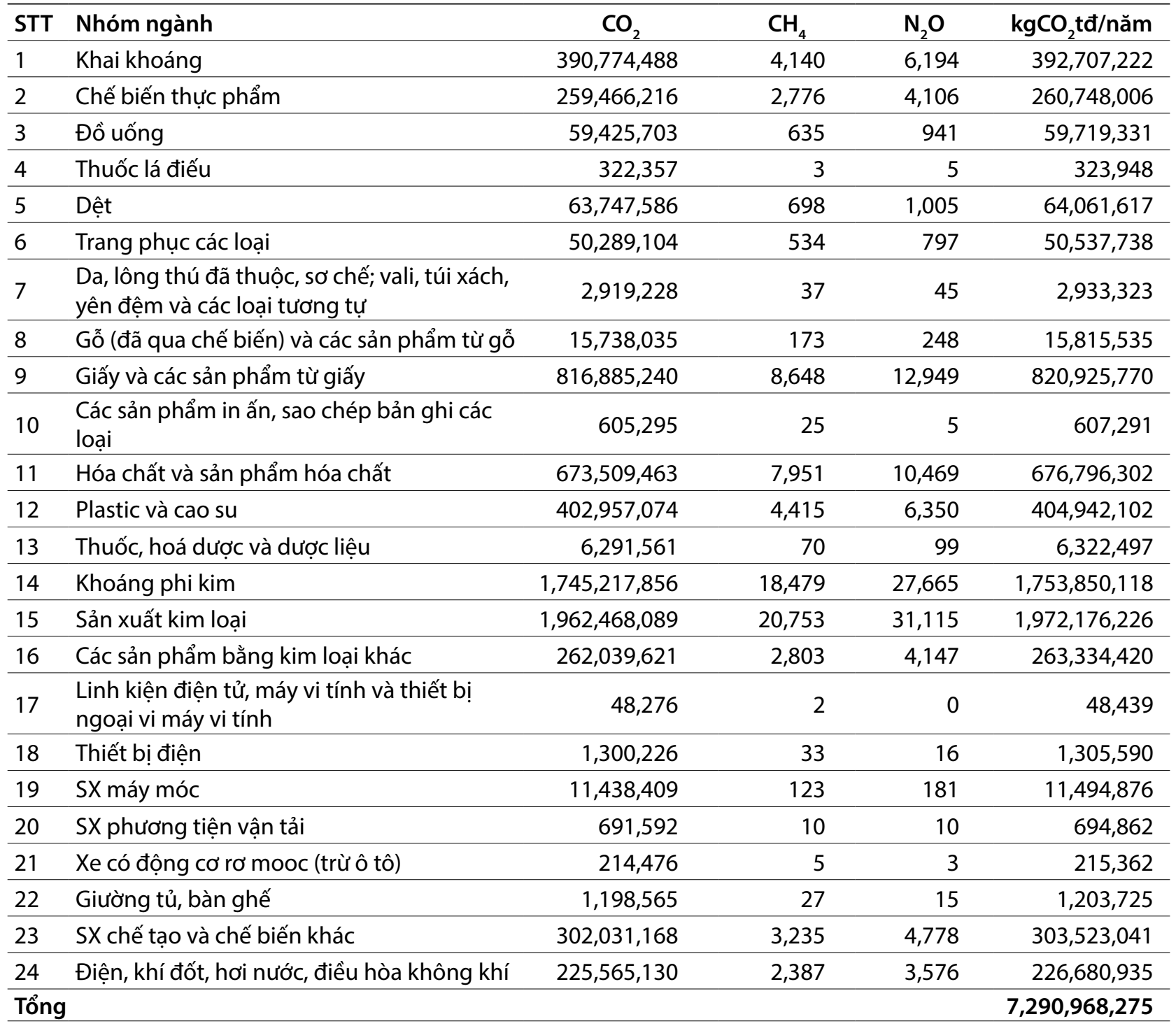

Nguồn: Sở khoa học và công nghệ Bình Dương 2014 
Phát thải KNK trong lĩnh vực tiêu thụ năng lượng tại tỉnh Bình Dương

(kg CO 2 tương đương)

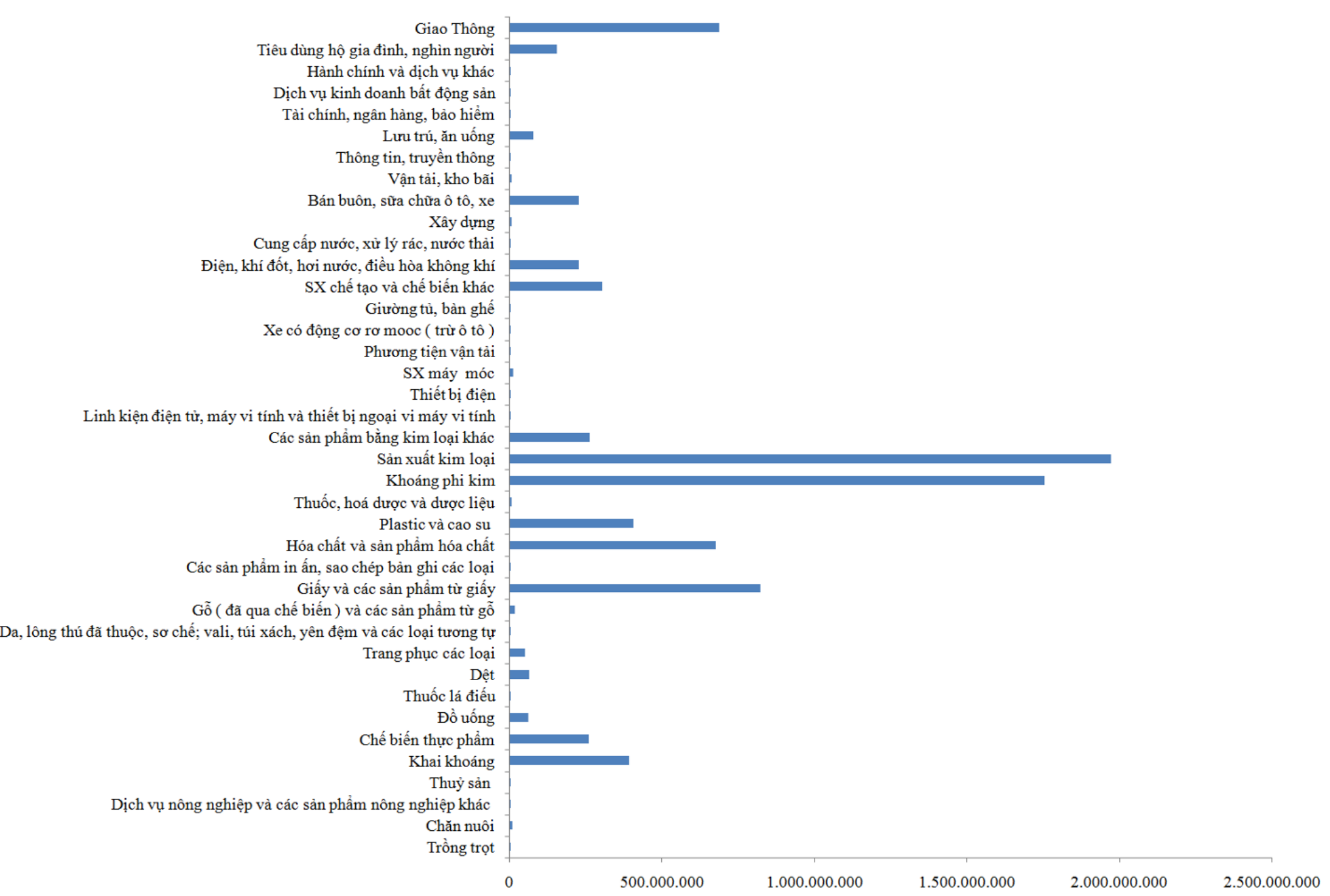

Hình 5. Phát thải KNK trong lĩnh vực tiêu thụ năng lượng tại tỉnh Bình Dương

Nguồn: Sở Khoa học và Công nghệ Bình Dương 
vệ môi trường đối với khai thác khoáng sản với mức 40,00-60,000/ tấn theo nghị định Số 164/2016/NĐ-CP (Chính phủ Việt Nam 2016). Thông lệ này cũng giống như nhiều quốc gia đang tiến hành trên thế giới. Tuy nhiên, tại Brazil, các công ty khai thác khoáng sản và sản xuất gang thép ngoài việc đóng phí bảo vệ môi trường còn phải chi trả và bồi hoàn cho dịch vụ môi trường bị mất đi thông qua việc chi trả để trồng mới, tái sinh và phục hồi rừng ngập mặn (Souza và cộng sự 2016). Cụ thể hơn, tại nhiều bang của Brazil như São Paulo, theo quy định của chính phủ, các công ty chỉ được cấp phép hoạt động khi họ có kế hoạch rõ ràng trong việc hồi phục hệ sinh thái tại khu vực họ đã phá rừng để sản xuất hoặc chi trả bồi hoàn cho dịch vụ môi trường rừng đã mất (Popak 2012). Tương tự như vậy, cơ chế bồi hoàn hệ sinh thái thông qua PES đã được áp dụng cho ngành khai thác khoáng sản, sản xuất than từ năm 1994 tại Trung Quốc (Hộp 1).

Bảng 3 và Bảng 4 cũng liệt kê một số dịch vụ môi trường rừng có thể đem lại cho ngành khai thác khoáng sản trong việc giảm phát thải của mình.

Kết quả rà soát tài liệu thứ cấp cho thấy, có khoảng 46 công ty khai thác khoáng sản và 50 công ty sản xuất gang, sắt, thép tại Hải Phòng (Bảng 5 và xem chi tiết ở Phụ lục 2 và 3 ).

\section{Hộp 1. Xây dựng chính sách bồi hoàn hệ sinh thái thông qua hoạt động trồng mới và tái trồng rừng, giảm phá rừng cho ngành khai thác khoáng sản tại Trung Quốc (Zhang và cộng sự 2010)}

Việc bồi hoàn này được sử dụng để phục hồi hệ sinh thái (trong đó có hệ sinh thái rừng) ở nơi khai thác khoáng sản. Từ cuối năm 1980s, nhiều tỉnh tại Trung Quốc bao gồm Phúc Kiến, Cam Túc, Quảng Đông, Quảng Tây, Hắc Long Giang, Khu Nội Mông, Giang Tô, Tây Sơn, và Thiểm Tây đã thu phí bồi hoàn hệ sinh thái để giải quyết các vấn đề môi trường mà các công ty khai thác và sản xuất khoáng sản đã gây ra. Dưới sự đồng ý thí điểm của Chính phủ, tập đoàn The Shenhua Group đã trả phí dịch vụ môi trường này với mức 0.45 nhân dân tệ tương đương khoảng 1,477 VND/tấn than vào năm 1993. Năm 1997, tỉnh Thiểm Tây thông qua chính sách thu phí bồi hoàn dịch vụ hệ sinh thái yêu cầu các cá nhân và doanh nghiệp tham gia vào việc khai thác khoáng sản phải trả phí bồi hoàn hệ sinh thái hàng tháng. Năm 1999, tỉnh Quý Châu thu 5 nhân dân tệ tương đương khoảng 16,420 VND/tấn than để phục hồi thảm thực vật. Cho tới năm 2002, đã có 17 tỉnh, thành phố, quận huyện trên toàn Trung Quốc thí điểm thu phí bồi hoàn hệ sinh thái này.

Nhiều tỉnh cũng đã xây dựng chính sách PES yêu cầu các công ty sản xuất khoáng sản ngoài việc trả phí bảo vệ môi trường còn phải trả dịch vụ môi trường để phục hồi lại vùng đất khai thác khoáng sản. Các công ty doanh nghiệp càng lạc hậu và càng phát thải nhiều thì càng phải đóng mức phí cao hơn trong việc phục hồi dịch vụ môi trường này. Nhiều tỉnh (VD: tỉnh Liêu Ninh) còn yêu cầu khi xin giấy phép khai thác khoáng sản, các công ty phải đóng tiền đặt cọc chi trả trước cho dịch vụ môi trường này. Nếu các công ty thực hiện đúng và đầy đủ việc phục hồi lại môi trường tại vùng đất họ đã phá hủy trong suốt quá trình sản xuất (bao gồm cả việc trả phí dịch vụ môi trường rừng) và đạt được yêu cầu của nhà nước họ sẽ nhận lại được $85 \%$ số tiền đặt cọc. 2 năm tiếp theo sau khi chấm dứt các hoạt động khai thác, các doanh nghiệp vẫn có trách nhiệm phục hồi lại môi trường và chỉ khi có bản đánh giá đầy đủ rằng họ đã hoàn thành trách nhiệm theo yêu cầu của nhà nước, họ sẽ được trả lại $15 \%$ số tiền đặt cọc và tiền lãi ngân hàng (Zhang và cộng sự 2010). Mục tiêu của chính sách này là để khuyến khích các doanh nghiệp và cá nhân thực hiện các nghĩa vụ mà họ phải làm để bảo vệ môi trường, còn nếu họ không làm được thì số tiền đặt cọc này sẽ được sử dụng để thuê các bên khác làm việc bảo vệ môi trường và phục hồi đất, trồng lại rừng (CCICED 2006).

Tại nhiều nơi, việc xác định mức thu phí này phụ thuộc vào tổng sản lượng khoáng sản được khai thác hoặc một phần của tổng doanh thu thu được. Một số tỉnh (VD: tỉnh Triết Giang) cũng có 2 cách tiếp cận đối với các doanh nghiệp mới được phép khai thác và các công ty khai thác cũ. Đối với các giấy phép khai thác mới, họ sẽ phải trả tiền vào một quỹ ủy thác một khoản phí theo từng diện tích khai thác khoáng sản để trả cho bên cung cấp dịch vụ môi trường. Đối với các vùng khai thác khoáng sản bị bỏ hoang, trong trường hợp không có người hưởng lợi hoặc khó có thể xác định được người hưởng lợi, chính phủ sẽ dùng nguồn thu này để trực tiếp phục hồi dịch vụ môi trường rừng tại nơi đó (CCICED 2006). 
Bảng 3. Các dịch vụ môi trường rừng cho hoạt động khai thác mỏ

\begin{tabular}{|c|c|c|c|c|}
\hline $\begin{array}{l}\text { Cách tiếp cận } \\
\text { sau việc khai } \\
\text { thác mỏ }\end{array}$ & $\begin{array}{l}\text { Hoạt động được thông } \\
\text { qua để phục hồi các } \\
\text { dịch vụ hệ sinh thái }\end{array}$ & $\begin{array}{l}\text { Hoạt động khai thác } \\
\text { chịu trách nhiệm cho } \\
\text { sự xói mòn đất }\end{array}$ & Dịch vụ môi trường & Nguồn \\
\hline \multirow[t]{5}{*}{$\begin{array}{l}\text { Trồng rừng } \\
\text { bằng cây tự } \\
\text { nhiên/bản địa }\end{array}$} & $\begin{array}{l}\text { Bón phân khoáng, thay } \\
\text { thế lớp đất nền và đất } \\
\text { mặt }\end{array}$ & Khai thác bô-xít & $\begin{array}{l}\text { Tăng hàm lượng chất hữu cơ } \\
\text { trong đất; phục hôi cấu trúc } \\
\text { sinh học của đất; tăng hàm } \\
\text { lượng vật chất khô tữ việc } \\
\text { bón phân xanh, tăng tỷ trọng } \\
\text { dinh dưỡng (nitơ, phốt pho } \\
\text { và kali) }\end{array}$ & Moreira 2004 \\
\hline & Trồng cây bản địa & Khai thác cát & $\begin{array}{l}\text { Cải thiện chất lượng đất } \\
\text { nền; tạo điều kiện tái sinh tự } \\
\text { nhiên }\end{array}$ & Almeida 2010 \\
\hline & Trồng cây bản địa & Khai thác cát & $\begin{array}{l}\text { Tạo điều kiện tái sinh rừng } \\
\text { (tăng tỷ lệ sống của cây non) }\end{array}$ & $\begin{array}{l}\text { Knapik và } \\
\text { Maranho } 2007\end{array}$ \\
\hline & $\begin{array}{l}\text { Tái sinh tự nhiên đồng } \\
\text { thời bảo tồn các diện } \\
\text { tích xung quanh }\end{array}$ & Khai thác vàng & $\begin{array}{l}\text { Thu hút hệ động vật phân } \\
\text { tán; tạo điều kiện cho sự sinh } \\
\text { trưởng kế tiếp }\end{array}$ & $\begin{array}{l}\text { Rodriguesvà } \\
\text { cộng sự. } 2004\end{array}$ \\
\hline & $\begin{array}{l}\text { Trồng cây Trinh nữ nhám } \\
\text { (Mimosa scabrella), theo } \\
\text { chất lượng đất có thể } \\
\text { thêm phân bón và rợm } \\
\text { rạ, và lắp đặt sào nhân } \\
\text { tạo }\end{array}$ & Khai thác đất sét & $\begin{array}{l}\text { Tạo thuận lợi cho tái sinh } \\
\text { rừng (độ che phủ của cây } \\
\text { càng lớn thì sẽ tạo điêu kiện } \\
\text { phân tán hạt giống, thúc đẩy } \\
\text { tái sinh tự nhiên) }\end{array}$ & $\begin{array}{l}\text { Regensburger } \\
2004\end{array}$ \\
\hline $\begin{array}{l}\text { Phục hồi rừng } \\
\text { bằng các loài } \\
\text { thương mại } \\
\text { ngoại lai }\end{array}$ & $\begin{array}{l}\text { Trồng Keo tai tượng } \\
\text { (Acacia Mangium) }\end{array}$ & Khai thác bô-xít & $\begin{array}{l}\text { Tăng sự đa dạng các loài nấm } \\
\text { cộng sinh trong rễ cây để } \\
\text { phục hồi chất lượng đất nền }\end{array}$ & $\begin{array}{l}\text { Caproni và } \\
\text { cộng sự } 2005\end{array}$ \\
\hline \multirow[t]{2}{*}{$\begin{array}{l}\text { Phục hồi sinh } \\
\text { học }\end{array}$} & $\begin{array}{l}\text { Sử dụng vi sinh bám rễ } \\
\text { (rhizobacteria) - nguồn } \\
\text { cung cấp các bào tứ } \\
\text { sinh sản vô tính, kết } \\
\text { hợp với việc trồng cây } \\
\text { Tibouchina urvilleana, } \\
\text { trong một khu vực đất bị } \\
\text { xuống cấp do chất thải } \\
\text { trong quá trình khai thác }\end{array}$ & Khai thác than & $\begin{array}{l}\text { Giảm ô nhiễm đất và nước; } \\
\text { tạo điê̂u kiện cho cây tăng } \\
\text { trưởng ở những khu vực bị } \\
\text { ô nhiễm bới kim loại nặng; } \\
\text { giảm độc tính từ kim loại } \\
\text { nặng cho rễ cây }\end{array}$ & $\begin{array}{l}\text { Pereira và } \\
\text { Castro-Silva } \\
2010\end{array}$ \\
\hline & $\begin{array}{l}\text { Sử dụng khuẩn tảo lục } \\
\text { (vi khuẩn quang hợp) }\end{array}$ & Khai thác vàng & Giảm ô nhiễm đất và nước & Souza 2007 \\
\hline
\end{tabular}

Nguồn: Souza và cộng sự 2016

Bảng 4. Dịch vụ môi trường rừng liên quan đến việc khai thác mỏ

\begin{tabular}{lll}
\hline Cách tiếp cận & Dịch vụ môi trường & Nguồn \\
\hline $\begin{array}{l}\text { Trồng lại cây/ } \\
\text { trồng rừng }\end{array}$ & Tăng mức độ dinh dương và mùn hữu cơ trong đất & $\begin{array}{l}\text { Grubb 1995, Kobayashi 2004, Macedo } \\
\text { và cộng sự 2008, Jeddi và Chaieb 2012 }\end{array}$ \\
\hline & Phục hồi năng suất, giảm xói mòn đất & Parrotta 1992, Montagnini 2000 \\
\hline & Tăng đa dạng sinh học, tăng tốc quá trình tái sinh & Guariguata và cộng sự 1995, Kuusipalo \\
& và cộng sự 1995, Haggar và cộng \\
sự 1997, Keenan và cộng sự 1997, \\
Lugo 1997, Parrotta và cộng sự 1997, \\
& $\begin{array}{l}\text { Powersvà cộng sự 1997, Keenan và } \\
\text { cộng sự 1999, Ashton và cộng sự 2001, } \\
\text { Carnevale và Montagnini 2002, Jeddi và } \\
\text { Chaieb 2012 }\end{array}$ \\
\hline
\end{tabular}


Bảng 4. Tiếp trang trước

\begin{tabular}{|c|c|c|}
\hline Cách tiếp cận & Dịch vụ môi trường & Nguồn \\
\hline & $\begin{array}{l}\text { Thúc đẩy sự đa dạng hoá của các nhóm nấm cộng } \\
\text { sinh trong rễ cây, tạo điêu kiện hình thành chuỗi } \\
\text { sinh thái }\end{array}$ & $\begin{array}{l}\text { Newsham và cộng sự 1995, Guerrero và } \\
\text { cộng sự 1996, Alguacil và cộng sự } 2011\end{array}$ \\
\hline & $\begin{array}{l}\text { Tạo điều kiện thiết lập hề thực vật, tạo thuận lợi cho } \\
\text { việc hấp thụ nước và chất dinh dưỡng, chống lại các } \\
\text { bệnh liên quan đến rễ cây (kết quả của sự đa dạng } \\
\text { hoá các nhóm nhám cộng sinh trong rễ cây) }\end{array}$ & Newsham và cộng sự 1995 \\
\hline & $\begin{array}{l}\text { Tái lập dự trữ các-bon trong đất; cô lập các-bon; cải } \\
\text { thiện chất lượng nước }\end{array}$ & Macedo và cộng sự 2008 \\
\hline & $\begin{array}{l}\text { Tạo điều kiện phục hồi đa dạng sinh học; thu hút hệ } \\
\text { động vật phân tán; tạo điêu kiện cho sự sinh trưởng } \\
\text { sinh thái; cung cấp gỗ cho hoạt động thương mại }\end{array}$ & Cusack và Montagnini 2004 \\
\hline \multirow{4}{*}{$\begin{array}{l}\text { Phục hồi rừng } \\
\text { bằng các loài } \\
\text { thương mại ngoại } \\
\text { lai }\end{array}$} & $\begin{array}{l}\text { Tạo điều kiện phát triển cho các loài thực vật có ít } \\
\text { khả năng chịu đựng các điều kiện bất lợi; cung cấp } \\
\text { lâm sản }\end{array}$ & McNamara và cộng sự 2006 \\
\hline & $\begin{array}{l}\text { Cải thiện điều kiện đất; tạo điều kiện phát triển cho } \\
\text { các loài thực vật có ít khả năng chịu đựng các điêuu } \\
\text { kiện bất lợi }\end{array}$ & $\begin{array}{l}\text { Lamb và Tomlinson 1993, Jeddi và } \\
\text { Chaieb } 2012\end{array}$ \\
\hline & Cải thiện/bảo tôn đa dạng sinh học & $\begin{array}{l}\text { McNamara và cộng sự 2006, Jeddi và } \\
\text { Chaieb } 2012\end{array}$ \\
\hline & $\begin{array}{l}\text { Bảo vệ tài nguyên nước; tăng khả năng phục hồi } \\
\text { trước các tác động môi trường tiêu cực }\end{array}$ & McNamara và cộng sự 2006 \\
\hline Phục hồi sinh học & Khử độc đất và nước & $\begin{array}{l}\text { Roitman và cộng sự 1987, Melo và } \\
\text { Azevedo 1998, Accioly và Siqueira 2000, } \\
\text { Pires và cộng sự 2003, Sprocati và cộng } \\
\text { sự 2006, Soares và Casagrande 2007, } \\
\text { Souza } 2007\end{array}$ \\
\hline $\begin{array}{l}\text { Trồng lại rừng } \\
\text { cộng đồng quản } \\
\text { lý }\end{array}$ & $\begin{array}{l}\text { Cải thiện sản xuất tài nguyên rừng; cung cấp gỗ và } \\
\text { các sản phẩm ngoài gỗ }\end{array}$ & Kobayashi 2004, Nawir và cộng sự 2007 \\
\hline \multirow[t]{5}{*}{$\begin{array}{l}\text { Trồng lại rừng } \\
\text { với các hệ thống } \\
\text { nông lâm kết hợp }\end{array}$} & Cung cấp sản phẩm nông lâm & $\begin{array}{l}\text { Brienza và cộng sự 1995, Amador 1999, } \\
\text { Armando và cộng sự 2002, Fávero và } \\
\text { cộng sự } 2008\end{array}$ \\
\hline & Cô lập các-bon & Jose 2009, Aerts và Honnay 2011 \\
\hline & Cải thiện dinh dưỡng đất & $\begin{array}{l}\text { Wadt 2003, Fávero và cộng sự 2008, } \\
\text { Jose 2009, Aerts và Honnay } 2011\end{array}$ \\
\hline & Cải thiện chất lượng nước & Jose 2009, Aerts và Honnay 2011 \\
\hline & $\begin{array}{l}\text { Cung cấp môi trường sống cho các loài chịu nhiễu } \\
\text { loạn môi trường; tạo điều kiện bảo tôn tế bào mầm } \\
\text { của các loài nhạy cảm; tạo điêuu kiện kết nối giữa tàn } \\
\text { dư rừng; kiểm soát sâu bệnh; thụ phấn thực vật và } \\
\text { phân tán hạt giống; thích ứng với lũ lụt; cải thiện } \\
\text { đất - tính chất vất lý, hóa học và sinh học; hạn chế } \\
\text { phân tán mùi và các hạt bụi trong không khí; giảm ô } \\
\text { nhiễm tiếng ôn }\end{array}$ & Jose 2009 \\
\hline \multirow[t]{3}{*}{$\begin{array}{l}\text { Kỹ thuật sinh học } \\
\text { đất }\end{array}$} & Chống xói mòn đất & $\begin{array}{l}\text { Pinheiro 1971, Fernandes 2004, Galas } \\
\text { 2006, Holanda và cộng sự } 2008\end{array}$ \\
\hline & $\begin{array}{l}\text { Giảm lượng nước tiếp cận đến đất, giảm áp lực lỗ } \\
\text { rỗng trong đất, tăng áp lực hút, tăng liên kết của rễ } \\
\text { và đất }\end{array}$ & Lemes 2001 \\
\hline & $\begin{array}{l}\text { Tạo điều kiện cho sự phát triển cho hệ thực vật ven } \\
\text { sông }\end{array}$ & Holanda và cộng sự 2008 \\
\hline
\end{tabular}

Nguồn: Souza và cộng sự 2016 
Bảng 5. Khai thác khoáng sản

\begin{tabular}{lcc}
\hline Ngành & Số lượng công ty, doanh nghiệp & Nguồn \\
\hline Khai thác khoáng sản & 46 & Cơ sở dữ liệu Thông tin doanh nghiệp 2020 \\
\hline Sản xuất gang thép & 50 & Thông tin Công ty tại Hải Phòng 2020 \\
\hline
\end{tabular}

\subsubsection{Ngành vận tải}

Ngành vận tải là một trong những ngành phát thải nhiều nhất trong các ngành nghề kinh tế và cũng là nhóm người mua tiềm năng cho dịch vụ môi trường rừng liên quan đến hấp thụ các-bon. Vào năm 2005, lượng khí thải cácbon $\left(\mathrm{CO}_{2}\right)$ của Việt Nam là 81.6 triệu tấn, trong đó 20.3 triệu tấn do ngành giao thông vận tải thải ra, chiếm đến $25 \%$. Cụ thể, $92 \%$ lượng khí thải $\mathrm{CO}_{2}$ là do giao thông vận tải đường bộ và khoảng $5 \%$ là từ giao thông vận tải đường thủy (nội địa và đường biển) thải ra bao gồm cả vận chuyển hàng hóa và vận chuyển hành khách.

Vận tải hàng không: Khí thải từ máy bay làm ô nhiễm khu vực nhạy cảm nhất của khí quyển. Tổ chức Liên chính phủ về thay đổi khí hậu (IPCC) từng cảnh báo rằng khói thải từ máy bay chiếm 3.5\% nguyên nhân làm cho trái đất ấm dần lên và theo Cơ quan Môi trường châu Âu, các chuyến bay từ châu Âu tạo ra lượng khí thải lên tới 440,000 tấn mỗi ngày (VnExpress 2001). Tại Peru, hãng hàng không lớn nhất Châu Mỹ La-tinh - LATAM - đã mua 7,000 tấn các-bon bồi hoàn từ một dự án trồng rừng của công ty tên là Bosques Amazonicos tại tỉnh Ucayali. Air France cũng đã mua tín chỉ các-bon tại Madagascar thông qua việc tài trợ dự án chống phá rừng (Kill 2014). Hải Phòng hiện đang hoạt động 1 cảng hàng không thương mại là cảng bay Cát Bi, việc sân bay Cát Bi với nhiều đường bay trong và ngoài nước cũng mở ra tiềm năng mới trong việc xây dựng cơ chế này tại Hải Phòng.

Vận tải đường thuỷ: Những ước tính gần đây cho thấy vận chuyển hàng hoá bằng công-tennơ đường biển có thể tiết kiệm nhiên liệu 17 lần so với đường hàng không và tiết kiệm 10 lần so với vận chuyển đường bộ. Về mặt môi trường, vận chuyển đường biển có thể làm giảm lượng khí thải nhà kính theo như Luis và El-Hifnawi (2014) đã nghiên cứu, vận tải đường thủy nội địa (đối với tàu trọng tải trên 250 DWT) và vận tải biển xả thải ít khí $\mathrm{CO}_{2}$ hơn trên mỗi tấn-km so với vận tải hàng hóa bằng đường bộ. Chi phí nhiên liệu chiếm 50-60\% tổng chi phí vận hành tàu, tùy thuộc vào loại tàu và loại dịch vụ, có nghĩa là giá vận chuyển sẽ tiếp tục phải chịu áp lực tăng lên vì các hãng vận tải biển sẽ phải bù đắp những chi phí này (Eimskip Vietnam 2018).

Mức giá tài chính của các dịch vụ giao thông vận tải không phản ánh được tất cả các chi phí và lợi ích xã hội, bao gồm chi phí ô nhiễm môi trường, khí thải nhà kính, tắc nghẽn giao thông, tai nạn giao thông, tiếng ồn cũng như là các tác động tích cực khác. Thông thường, chi phí vận tải đường thủy nội địa và đường biển sẽ tốt hơn so với tận đường bộ, xét về những tiêu chí trên. Lượng phát thải từ các phương thức vận tải khác nhau trên mỗi tấn hoặc tấn-km có thể khác nhau một cách đáng kể. Đáng chú ý, tác động từ mật độ của giao thông vận tải đường thủy nội địa hay các tác động tích cực có thể tạo ra những lợi ích kinh tế, có thể được diễn giải như sau: nếu mức độ giao thông vận tải đường bộ tăng sẽ dẫn tới tắc nghẽn giao thông tăng, từ đó làm tăng chi phí vận hành phương tiện vận tải và chi phí thời gian, thêm vào đó, khi mật độ giao thông và yếu tố tải trọng của xe tải cao hơn, chi phí hoạt động của mạng lưới giao thông đường bộ (chi phí bảo trì và hao mòn) sẽ tăng lên; ngược lại, khi mức độ vận tải biển và đường thủy nội địa tăng có thể mang lại các tác động tích cực như là sử dụng tàu hàng lớn hơn dẫn đến chi phí vận chuyển thấp hơn và cường độ dịch vụ logistics cao hơn, từ đó giảm chi phí vận chuyển hàng tồn kho, hàng đọng cho các bên xuất - nhập khẩu. Lượng khí thải nhà kính tăng khi mức độ tắc nghẽn giao thông ở mức cao, vốn là vấn đề thường xảy ra với giao thông đường bộ (Luis và El-Hifnawi 2014).

Lượng phát thải từ hoạt động giao thông vận tải đường bộ và đường thủy chịu ảnh hưởng lớn bởi kích cỡ và thời gian sử dụng của xe, tàu vận chuyển. Luis và El-Hifnawi 2014 khẳng định tỷ trọng phát thải của vận tải đường bộ sẽ nhiều gấp khoảng từ 1.2 đến 1.8 lần so với vận tải đường thủy nội địa và đường biển thải ra, 


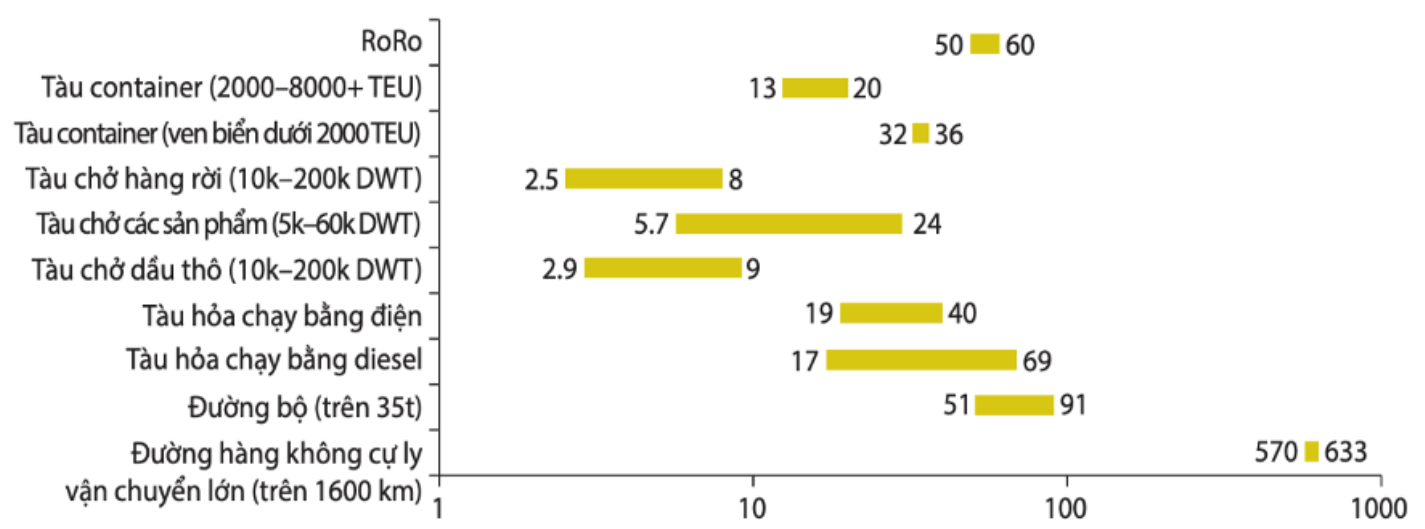

\section{Hình 6. Mật độ $\mathrm{CO}_{2}$ trên các phương thức vận tải được chọn, thang Lôga (g/tấn-km)}

Nguồn: Luis và El-Hifnawi 2014, diễn đàn Vận tải Quốc tế (ITF) dự đoán và Buhaug và các cộng sự. 2008, như đã trình bày trong Crist năm 2009

mặc dù tính theo đơn vị tấn-km vận chuyển của đường bộ thấp hơn.

Hình 6, Hình 7 và Hình 8 thể hiện phạm vi phát thải trên mỗi tấn-km hàng hóa được vận chuyển bằng các phương thức vận tải khác nhau. Một điểm đáng chú ý rằng các ước tính này được dành cho các nước châu Âu và các quốc gia thuộc Tổ chức Hợp tác và Phát triển Kinh tế $(O E C D)$; và đối với các nền kinh tế mới nổi, đang phát triển, nơi dành rất ít nguồn lực cho các phương tiện vận tải, bảo trì cơ sở hạ tầng và thường có môi trường giao thông kém hiệu quả, hệ số phát thải cao (hoặc ít nhất là ở mức trung bình trên trong giới hạn đặt ra) được áp dụng nhiều hơn. Lượng phát thải các-bon của tàu biển công-ten-nơ chỉ bằng khoảng $1 / 3$ so với xe tải lớn. Theo đó lượng khí phát thải từ xe tải hạng nặng ở trong khoảng 51 đến $91 \mathrm{~g}$ trên mối tấn-km, trong khi đó lượng khí thải từ các tàu biển công-ten-nơ chỉ nằm ở ngưỡng từ 32 đến $36 \mathrm{gCO}_{2}$ (xem hình 6).

Hình 7 cung cấp các mức ước lượng phù hợp hơn với đặc thù hiện nay của Việt Nam (chủ yếu là xe tải và tàu vận tải nội địa tương đối nhỏ và kém hiệu quả). Theo hình 7, mật độ các-bon trung bình của tàu vận tải đường thủy chỉ ở mức từ 30 đến $60 \mathrm{gCO}$ trên mỗi tấn-km, xấp xỉ một nửa so với mức 70 đến $110 \mathrm{gCO}_{2}$ trên mỗi tấn-km của mật độ các-bon trung bình của xe tải (Luis và El-Hifnawi 2014).

Loại hình hàng hóa chiếm ưu thế nhất đối với vận tải đường thủy nội địa của Việt Nam được chuyên chở bằng tàu nội địa tương đối nhỏ (dưới 250 tấn). Lượng khí phát thải từ vận chuyển hàng hóa bằng đường bộ đối với tàu vận tải nội địa ở mức 30 đến $160 \mathrm{~g} \mathrm{CO}$ trên mỗi tấn- $\mathrm{km}$ và 60 đến $80 \mathrm{~g} \mathrm{CO}_{2}$ trên mỗi tấn- $\mathrm{km}$ đối với xe tải (Luis và El-Hifnawi 2014).

Tính theo số lượng tàu, hệ số phát thải trung bình của đội tàu ở Việt Nam năm 2000 được ước tính ở mức $146 \mathrm{~g} \mathrm{CO}_{2}$ trên mỗi tấn-km và đến năm 2010 giảm xuống còn $137 \mathrm{~g} \mathrm{CO}$ trên mỗi tấn-km. Tính theo mức tải trọng, hệ số phát thải trung bình của đội tàu ở Việt Nam năm 2000 được ước tính ở mức $110 \mathrm{~g} \mathrm{CO}$ trên mỗi tấn-km và đến năm 2010 giảm xuống còn $71 \mathrm{~g} \mathrm{CO}_{2}$ trên mỗi tấn-km (Bảng 6, Luis và ElHifnawi 2014).

Tiếp đến, tổng lượng khí thải $\mathrm{CO}_{2}$ từ vận tải đường thủy nội địa Việt Nam được ước tính bằng hệ số phát thải trung bình của đội tàu và lưu lượng giao thông (Bảng 7). Có hai kịch bản được thể hiện ở các cột năm 2030. Kịch bản "mở rộng và hiện đại hóa" giả định rằng hệ số phát thải của đội tàu Việt Nam sẽ giảm từ 71 xuống còn $50 \mathrm{~g} \mathrm{CO}$ trên mỗi tấn-km trong giai đoạn từ năm 2010 đến năm 2030. Kịch bản hệ số phát thải "đóng băng" (nghĩa là chỉ dừng ở mức đường cơ sở) giả định rằng sau năm 2010 hệ số phát thải không giảm xuống nữa. Ước tính vào năm 2030, lượng phát thải hàng năm giảm xuống đạt mức khoảng 1 triệu tấn $\mathrm{CO}_{2}$. Để đạt được điều này, dự kiến sẽ nhờ một phần ở thị trường và một phần nhờ các chính sách ưu đãi đến từ chính phủ. Ước tính sơ bộ về mức giảm khí thải nhà kính nếu giả định tiến hành chuyển đổi $10 \%$ phương thức vận chuyển 


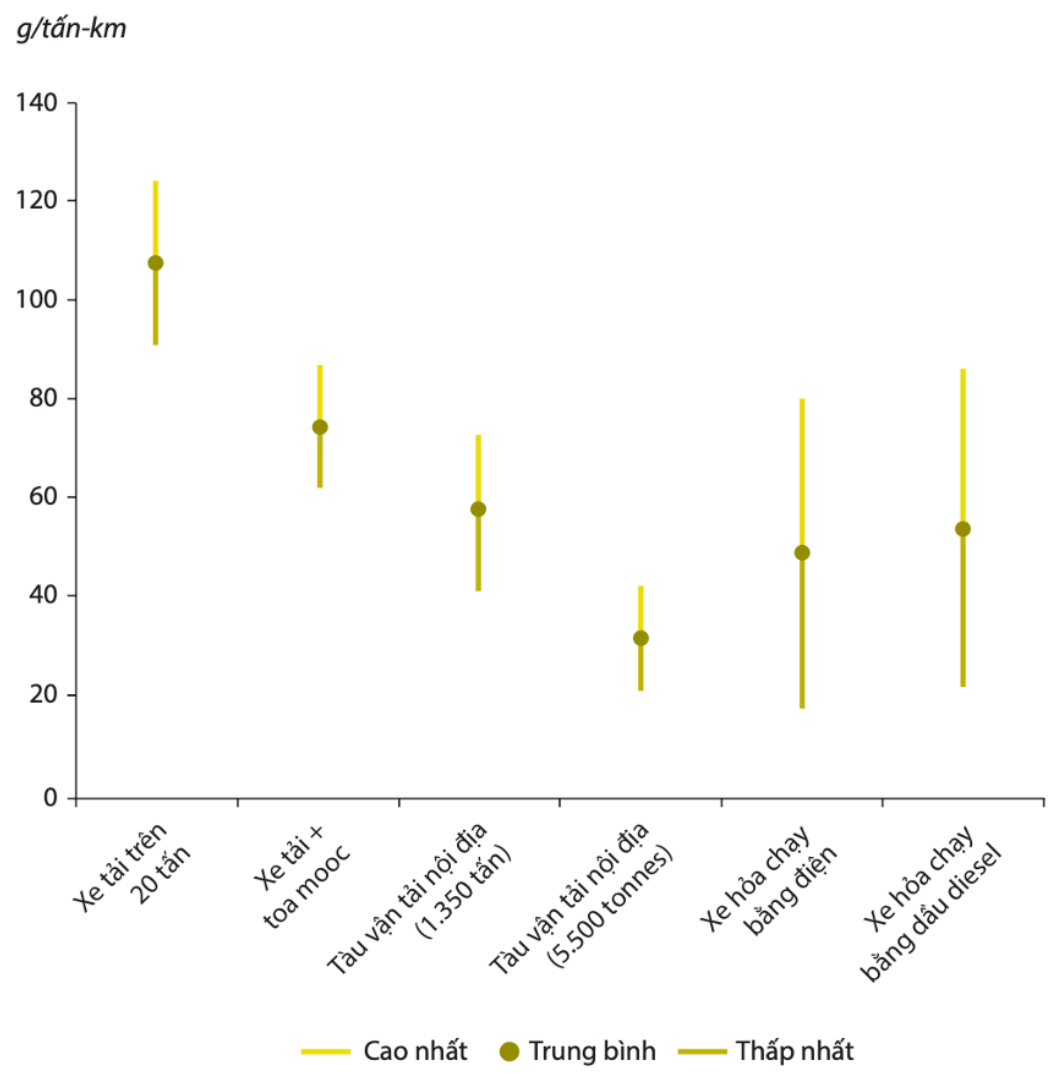

Hình 7. Lượng phát thải khí $\mathrm{CO}_{2}$ (g/tấn-km), Vận tải hàng hoá tuyến đường dài (>150 km), năm 2010

Nguồn: Luis và El-Hifnawi 2014, Cơ quan Thông tin Vận tải Nội địa Hà Lan, năm 2009.

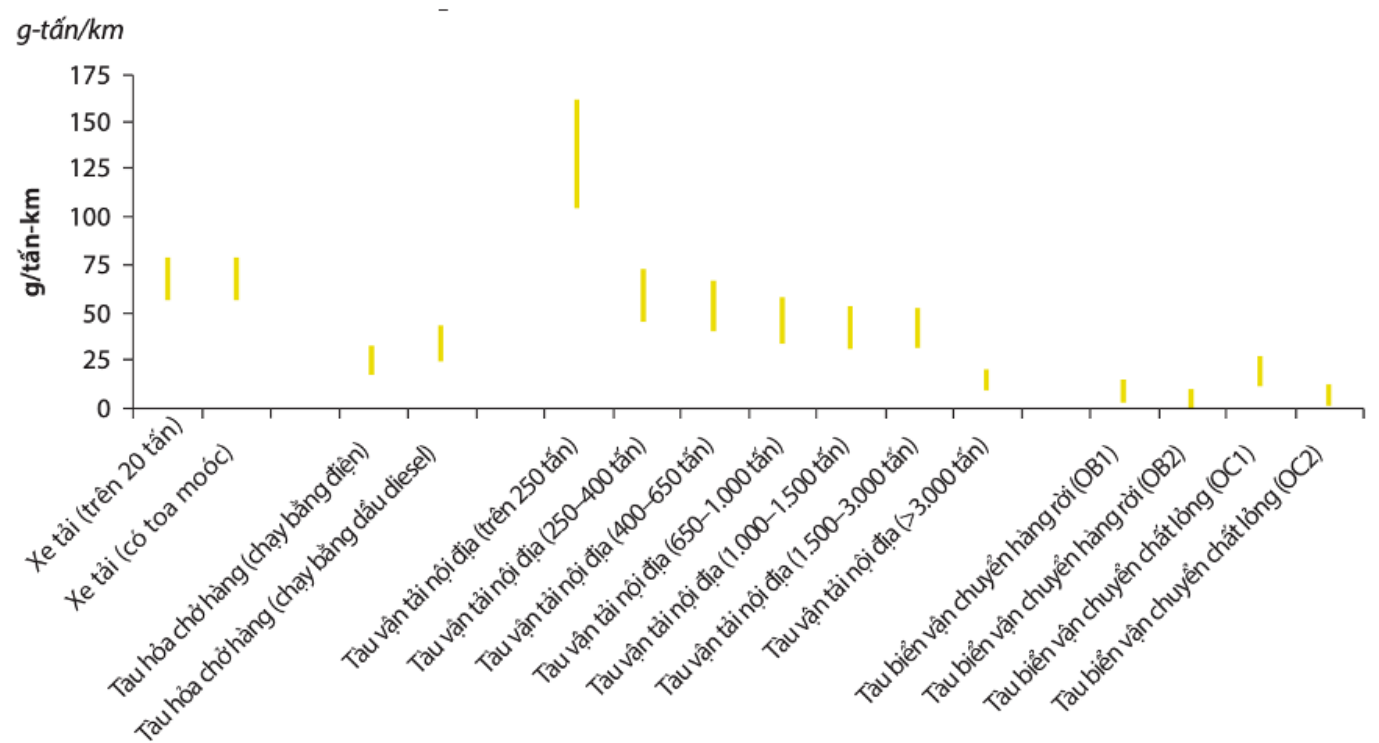

Hình 8. Lượng phát thải khí $\mathrm{CO}_{2}$ đối với vận tải hàng rời tuyến dường dài, năm 2000 Nguồn: Luis và El-Hifnawi 2014, Van Essen và cộng sự. 2003. 
Bảng 6. Tình hình tiến triển của lượng phát thải từ đội tàu VTĐTNĐ ở Việt Nam

\begin{tabular}{|c|c|c|c|}
\hline Trọng tải (DWT) và công suất tàu VTĐTNĐ & $\begin{array}{l}\text { Hệ số phát thải của tàu VTĐTNĐ } \\
\qquad \mathrm{gCO}_{2} \text { trên mỗi tấn-km }\end{array}$ & $\begin{array}{l}\text { Số lượng tàu } \\
\text { vào năm } 2000\end{array}$ & $\begin{array}{l}\text { Số lượng tàu } \\
\text { vào năm } 2010\end{array}$ \\
\hline 5-15 tấn và 5-15 HP & 160 & 22,531 & 53,239 \\
\hline $15-50$ tấn và $15-50 \mathrm{HP}$ & 130 & 7,875 & 23,902 \\
\hline 50-200 tấn và 50-135 HP & 100 & 2,749 & 9,266 \\
\hline 200-300 tấn và >135 HP & 75 & 340 & 1,248 \\
\hline 300-500 tấn và > 135 HP & 60 & 239 & 2,989 \\
\hline 500-700 tấn và > 135 HP & 50 & 88 & 1,613 \\
\hline 700-1.000 tấn và > 135 HP & 45 & 33 & 1,641 \\
\hline > 1.000 tấn và > 135 HP & 40 & 4 & 1,228 \\
\hline $\begin{array}{l}\text { Hệ số phát thải trung bình tính theo số } \\
\text { lượng tàu ( } \mathrm{gCO}_{2} \text { trên mỗi tấn-km) }\end{array}$ & n.a. & 146 & 137 \\
\hline $\begin{array}{l}\text { Hệ số phát thải trung bình tính theo trọng } \\
\text { tải của tàu }\left(\mathrm{gCO}_{2} \text { trên mỗi tấn-km) }\right.\end{array}$ & n.a. & 110 & 71 \\
\hline
\end{tabular}

Nguồn: Luis và El-Hifnawi 2014

Ghi chú: $\mathrm{DWT}=$ tổng trọng tải; $\mathrm{EF}$ = Hệ số phát thải; $\mathrm{HP}=$ mã lực; VTĐTNĐ = vận tải đường thủy nội địa. $\mathrm{CO}_{2}$ trên mỗi tấn-km

\section{Bảng 7. Kết quả thu được từ việc hiện đại hoá và nâng cấp đội tàu}

\begin{tabular}{lccc}
\hline $\begin{array}{l}\text { Lượng khí thải } \mathrm{CO}_{2} \text { từ VTĐTNĐ } \\
\text { ơ Việt Nam }\end{array}$ & 2010 & $\begin{array}{c}\text { Mở rộng quy mô và } \\
\text { hiện đại hóa đội tàu } \\
\text { năm } 2030\end{array}$ & $\begin{array}{c}\text { Hiệu suất phát } \\
\text { thải “đóng băng” } \\
\text { năm } 2030\end{array}$ \\
\hline $\begin{array}{l}\text { Hiệu suất phát thải trung bình của đội tàu VTĐTNĐ }\left(\mathrm{gCO}_{2} /\right. \\
\text { tấn-km) }\end{array}$ & 71 & 50 & 71 \\
\hline VTĐTNĐa tấn-km (tỉ tấn-km) & 23 & 48 & 48 \\
\hline Lượng khí thải $\mathrm{CO}_{2}$ từ (triệu tấn $\left.\mathrm{CO}_{2}\right)$ & 1.6 & 2.4 & 3.4 \\
\hline
\end{tabular}

Nguồn: Luis và El-Hifnawi 2014

Ghi chú: $\mathrm{EF}$ = hệ số phát thải; VTĐTNĐ = vận tải đường thủy nội địa. a. Dựa trên tốc độ tăng trưởng hàng năm ở mức 3.7\% đối với VTĐTNĐ trong giai đoạn từ năm 2008 đến năm 2030 theo số liệu của JICA năm 2009.

\section{Bảng 8. Kết quả sơ bộ thu được từ chuyển đổi phương thức vận tải hàng hoá từ đường bộ} sang đường thuỷ

\begin{tabular}{|c|c|c|}
\hline Lượng khí thải $\mathrm{CO}_{2}$ từ VTĐTNĐ ở Việt Nam & 2010 & 2030 \\
\hline Hệ số phát thải trung bình của đội xe tải (gCO 2 tấn-km) & 110 & 80 \\
\hline Hệ số phát thải trung bình của đội tàu VTĐTNĐ ( $\mathrm{gCO}_{2} /$ tấn-km) & 71 & 50 \\
\hline Đường bộ tấn-km (tỉ tấn-km) & 30 & 129 \\
\hline Lượng khí thải $\mathrm{CO}_{2}$ (triệu tấn $\mathrm{CO}_{2}$ ) & 3.3 & 10.3 \\
\hline Tỷ trọng vận tải đường bộ trừ đi 10\%: tấn-km đường bộ (tỉ) & & 116 \\
\hline Chuyển đổi phương thức đối với VTĐTNĐ: tấn-km đường thủy (tỉ) & & 13 \\
\hline Lượng khí thải $\mathrm{CO}_{2}$ (tỉ tấn) & & 9.3 \\
\hline $\begin{array}{l}\text { Lượng khí thải } \mathrm{CO}_{2} \text { từ chuyển đổi vận chuyển hàng hóa từ đường bộ sang VTĐTNĐ } \\
\text { (triệu tấn) }\end{array}$ & & 0.6 \\
\hline Trường hợp chuyển đổi phương thức vận tải đường bộ + VTĐTNĐ/ (triệu tấn $\mathrm{CO}_{2}$ ) & & 9.9 \\
\hline Tổng lượng khí thải $\mathrm{CO}_{2}$ giảm do chuyển đổi phương thức vận tải (triệu tấn $\mathrm{CO}_{2}$ ) & & 0.4 \\
\hline
\end{tabular}

Nguồn: Luis và El-Hifnawi 2014

Ghi chú: EF = hệ số phát thải; VTĐTNĐ = vận tải đường thủy nội địa. 
từ vận tải đường bộ sang vận tải đường thủy được thể hiện trong bảng 7. Ước tính sơ bộ hệ số phát thải dành cho xe tải ở Việt Nam dựa trên các đánh giá của chuyên gia được sử dụng trong Bảng 7 (Luis và El-Hifnawi 2014).

Trong ví dụ này, vào năm 2030, tổng lượng phát thải giảm hàng năm nhờ thực hiện việc chuyển đổi phương thức vận tải là 4 triệu tấn $\mathrm{CO}_{2}$. So sánh Bảng 7 và Bảng 8 , các kết quả ban đầu cho thấy rằng việc cho phép sử dụng các tàu lớn hơn và có động cơ hiện đại, ít khí thải hơn là cách đi hiệu quả nhất đối với Việt Nam, trong điều kiện tất cả các yếu tố khác không đổi, để giảm khí thải từ việc vận chuyển hàng hóa. Đặc biệt, tác động của các biện pháp này lớn hơn cả biện pháp giảm khí thải bằng cách chuyển đổi phương thức vận tải từ đường bộ sang đường thủy, ngay cả khi giả định tích cực về mức chuyển đổi hình thức vận tải lên đến $10 \%$. Chính vì vậy, Việt Nam cần ưu tiên cho các chính sách về việc sử dụng tàu và động cơ (Luis và El-Hifnawi 2014).

\subsubsection{Công ty năng lượng}

Vào cuối năm 2010, công ty năng lượng của Đức Stadtwerke Münster đã kết hợp với dự án Bảo tồn Voọc tại Cát Bà để tài trợ cho một dự án trồng rừng (cả trên cạn lẫn rừng ngập mặn) với tổng số tiền là 67,700 EURO để giảm phát thải khí nhà kính thông qua việc hấp thụ các-bon tại Vườn Quốc Gia Cát Bà (Leonard 2018). Kết quả phỏng vấn cho thấy việc công ty năng lượng Đức này đầu tư tự nguyện vào dự án là bởi họ phải đền bù lượng phát thải gây ra tại nước sở tại. Việc đầu tư dự án này cũng giúp nâng cao và quảng bá hình ảnh của công ty thông qua các hoạt động hỗ trợ cộng đồng và đảm bảo đa dạng sinh học.

\subsubsection{Ngành giải trí - làm phim điện ảnh}

Tập đoàn giải trí Walt Disney đã mua 437,000 tín chỉ các-bon từ Alto Myao Initiatve, một dự án ở phía bắc của tỉnh San Martin do chính phủ Peru và Conservation International tài trợ (Butler 2013). Walt Disney cũng đã mua rất nhiều tín chỉ các-bon từ các dự án REDD+ ở DRC để bồi hoàn phát thải cho các hoạt động kinh doanh của mình. Việc mua bán tín chỉ các-bon của Walt Disney được áp dụng tới từng bộ phận sản xuất của họ. Trong nhiều năm, bộ phận tàu thuyền và ô tô là đơn vị mua nhiều tín chỉ các-bon nhất. Walt Disney cũng làm rõ quan điểm của họ trên truyền thông rằng tập đoàn luôn tích cực quan tâm tới việc bảo vệ môi trường từ việc trồng rừng và mua các-bon. Họ cũng bày tỏ rõ quan điểm mong muốn và ưu tiên phát triển từ các hoạt động mới và địa bàn mới thay vì mua tại các điểm đã có hoạt động trong nhiều năm. Trong tương lai, đây hoàn toàn có thể là ngành dịch vụ tiềm năng cho Hải Phòng nói riêng và cả nước nói chung.

\subsubsection{Cảng biển}

Cảng biển là một trong những ngành tạo ra phát thải lớn trên toàn cầu do các hoạt động tại cảng đều sử dụng xăng dầu. Cảng Rotterdam của Hà Lan phát thải ít nhất là 60 triệu tấn $\mathrm{CO}_{2} /$ năm trong khi đó lượng phát thải ròng của toàn Anh trong cùng năm chỉ có 364 triệu tấn (The Guardian 2019). Hiện nay trên thế giới, để thực hiện cam kết giảm phát thải của quốc gia, nhiều cảng đã thực hiện cả biện pháp cứng (ví dụ: phát triển hệ thống chôn khí thải các-bon dưới biển như ở Na Uy và Hà Lan) đồng thời kết hợp với các biện pháp mềm như thực hiện các biện pháp chính sách chi trả cho bảo vệ và phát triển rừng ngập mặn (ví dụ: Mỹ, Úc), trong đó có cơ chế chi trả dịch vụ môi trường rừng.

Quy hoạch phát triển hệ thống cảng biển Việt Nam đến năm 2020, định hướng đến năm 2030 chia thành 6 nhóm cảng biển với 45 cảng biển đang hoạt động (Bảng 9) trong đó: 2 cảng cửa ngõ quốc tế (cảng biển loại $I A$ ); 12 cảng tổng hợp đầu mối khu vực (cảng biển loại I); 18 cảng tổng hợp địa phương (cảng biển loại II) và 13 cảng dầu khí ngoài khơi (cảng biển loại III) (Thủ tướng Chính phủ 2014). Cũng theo Quyết định 1037/QĐ-TTg 2014 phê duyệt điều chỉnh quy

Bảng 9. Số lượng cảng tại Hải Phòng

\begin{tabular}{lcl}
\hline Ngành & $\begin{array}{c}\text { Số } \\
\text { lượng }\end{array}$ & \multicolumn{1}{c}{ Nguồn } \\
\hline Cảng, bến cảng & 49 & $\begin{array}{l}\text { Bộ giao thông vận } \\
\text { tải 2019- Quyết Định } \\
\text { 616/QĐ-BGTVT }\end{array}$ \\
\hline Cảng biển & 45 & $\begin{array}{l}\text { Thủ tướng Chính phủ } \\
\text { 2014 }\end{array}$ \\
\hline $\begin{array}{l}\text { Cảng vận chuyển } \\
\text { than }\end{array}$ & 9 & $\begin{array}{l}\text { Tổng công ty tư vấn } \\
\text { và thiết kế GTVT - } \\
\text { CTCP 2015 }\end{array}$ \\
\hline Cảng cá, bến cá & 13 & $\begin{array}{l}\text { Tài nguyên và Môi } \\
\text { trường 2018a }\end{array}$ \\
\hline
\end{tabular}




\section{Bảng 10. Các chất ô nhiễm không khí tiềm tàng khi sử dụng thiết bị phun mài khô}

\begin{tabular}{ll}
\hline Nguồn gốc & Các chất ô nhiễm tiềm tàng \\
\hline $\begin{array}{l}\text { Vật liệu cơ bản (VD: Thép, Thép không gî, Thép mạ kẽm, } \\
\text { Đống - Niken và các hợp kim đồng khác) }\end{array}$ & $\begin{array}{l}\text { Nhôm, cadimi, crôm, đồng, sắt, chì, mangan, niken và } \\
\text { kẽm }\end{array}$ \\
\hline $\begin{array}{l}\text { Sơn phủ bề mặt tàu: (VD: Sơn lót, Sơn chống ăn mòn, Sơn } \\
\text { chống hàu) }\end{array}$ & $\begin{array}{l}\text { Đồng, bari, cadimi, crôm, chì, hợp chất Tributyltin, } \\
\text { kẽm }\end{array}$ \\
\hline $\begin{array}{l}\text { Vật liệu dùng để phun mài: kim loại (VD: sạn kim loại, mạt } \\
\text { giũa thép); xî (VD: xỉ than, xỉ đồng, xî niken); và các oxit } \\
\text { (VD: oxit nhôm, silicon carbide, cát sillica) }\end{array}$ & $\begin{array}{l}\text { Asen, beri, silic vô định hình, cadim, crôm, côban, tinh } \\
\text { thể, silca, chì, mangan, niken, bạc, titan, và vanadi }\end{array}$ \\
\hline
\end{tabular}

Nguồn: Kura và cộng sự 2006, OSHA 2006

hoạch phát triển hệ thống cảng biển Việt Nam đến năm 2020, định hướng đến năm 2030, Việt Nam sẽ tập trung xây dựng cảng cửa ngõ quốc tế tại Hải Phòng, tiếp nhận được tàu trọng tải đến 100,000 tấn (tàu công-ten-nơ 8,000 TEU) hoặc lớn hơn, đủ năng lực để có thể kết hợp vai trò trung chuyển container quốc tế; các cảng chuyên dùng quy mô lớn cho các liên hợp luyện kim, lọc hóa dầu, trung tâm nhiệt điện sử dụng than. Hội nghị lần thứ 4 Ban chấp hành Trung ương Đảng khóa $X$ đã thông qua Nghị quyết số 09-NQ/TW ngày $9 / 2 / 2007$ về Chiến lược biển Việt Nam đến năm 2020, trong đó đề ra mục tiêu cho tới năm 2020, các KKT ven biển sẽ đóng góp khoảng 53-55\% tổng GDP của cả nước và sẽ phát triển theo hướng đổi mới công nghệ, giảm phát thải khí nhà kính (KNK), hướng tới nền kinh tế các-bon thấp (Dương 2018).

Hiện nay, hệ thống cảng Hải Phòng là một cụm cảng biển tổng hợp cấp quốc gia lớn nhất miền Bắc và lớn thứ 2 ở Việt Nam với 5 cửa sông đổ ra biển là cửa ngõ quốc tế. Cụm cảng bao gồm 40 cảng và 69 cầu cảng với tổng chiều dài $42 \mathrm{~km}$ có nhiều chức năng như vận tải hàng dời, vật tư, sắt thép, công-ten-nơ, chất hóa lỏng ... Trong vòng 05 năm trở lại đây, với mức tăng trưởng tổng sản lượng thông qua cảng ước tăng trưởng bình quân $12.72 \% /$ năm. Khu vực Hải Phòng có khoảng 600 tàu biển đăng ký hoạt động, chiếm 35.5\% tổng số tàu đăng ký trong toàn quốc, với tổng số tấn trọng tải 2.76 triệu DWT, chiếm $37 \%$ tổng trọng tải của đội tàu cả nước. Số lượng tàu đăng ký hoạt động và trọng tải tàu tăng cả về quy mô và chất lượng vận chuyển, nhiều tàu có trọng tải trên 56,000 DWT đã được đưa vào khai thác. Đội tàu biển tư nhân phát triển nhanh. Nhiều tuyến vận tải đi các nước châu Âu, châu Mỹ, Úc, ... đã được mở ra, đặc biệt là tuyến vận tải hàng côngten-nơ, vận tải hàng khô, đã góp phần đưa hàng hóa Việt Nam xuất khẩu đi các nước như Mỹ, Châu Âu, châu Phi (Trần và Đỗ 2018).
Theo báo cáo của USAID nghiên cứu về rừng ngập mặn và cảng biển ở Việt Nam, trong đó có cảng biển ở Hải Phòng (Sommerville 2016), cảng thường được xây dựng ở cửa sông và khu vực được bảo vệ khỏi tác động trực tiếp của sóng. Cảng biển tại nhiều nơi còn tạo ra ô nhiễm không khí gây ảnh hưởng nghiêm trọng đến đến đời của người dân (UNEP 2016). Nhiều báo cáo của các cơ quan chức năng tại Việt Nam (Ha 2009; Tạp chí giao thông 2019) cũng chỉ rõ việc xây dựng và vận hành cảng đã gây ô nhiễm môi trường không khí:

- Khi cảng hoạt động, môi trường không khí trong khu vực bị ô nhiễm khí độc, bụi và tiếng ồn (Bảng 10).

- Ô nhiễm khí độc thường xảy ra ở các cảng chuyên dụng như cảng dầu, khí hoặc các cảng có mật độ tàu thuyền lớn thường xuyên thải ra một lượng khí độc giàu $\mathrm{CO}_{2}, \mathrm{NO}_{2}, \mathrm{SO}_{2}$.

- Ô nhiễm bụi do quá trình bốc dỡ thường xuyên các loại hàng hóa, đặc biệt là các loại hàng rời như than, xi măng, quặng sắt, hoặc do các phương tiện vận tải đường bộ trong cảng gây ra.

- Ô nhiềm tiếng ồn do các phương tiện giao thông đường bộ, tàu bè, các nhà máy sửa chữa, đóng mới tàu tạo nên. Trên thực tế, tiếng ồn trong khu vực cảng dao động từ 60-80dBA (Tiêu chuẩn môi trường là $55 \mathrm{dBA}$ ).

- Khí thải từ tàu biển có thể lan truyền ảnh hưởng đến môi trường và khu vực dân cư sinh sống. Khí thải từ các tàu biển chủ yếu bao gồm các-bon dioxide $\left(\mathrm{CO}_{2}\right)$, hơi nước, nitơ oxit (NOx), lưu huỳnh oxit (SOx), hạt vật chất (PM), cacbon monoxide (CO) và các hợp chất hữu cơ dễ bay hơi (VOC), bao gồm hợp chất hydrocarbon không cháy (UC).

Trong giai đoạn vận hành cảng, các tàu, sà lan vận chuyển hàng hóa và hoạt động của các máy móc bốc dỡ hàng hóa phát sinh nhiều khí thải độc hại. Theo đó, các động cơ đốt trong chạy 
bằng nhiên liệu diesel, thường là máy chính và các máy phát điện trên tàu, thải ra các khí độc hại như $\mathrm{CO}_{2}, \mathrm{CO}, \mathrm{NO}_{2}, \mathrm{C}_{m} \mathrm{H}_{\mathrm{n}^{\prime}} \mathrm{RCHO}$ và muội than vào môi trường không khí. Lượng khí thải từ các động cơ tàu thủy là nguồn ô nhiễm không khí đáng kể nhất của phương thức vận tải biển. Thêm vào đó, một lượng lớn bụi và hơi hóa chất, hơi xăng dầu nếu không có biện pháp kiểm soát cũng sẽ phát sinh trong quá trình bốc dỡ và vận chuyển các loại hàng hóa, nguyên liệu, nhiên liệu (than đá, xăng, dầu, hóa chất, phân hóa học) từ tàu lên các kho, bãi chứa và từ các bãi chứa xuống tàu. Trong các ngày có gió mạnh, bụi từ bãi chứa nguyên liệu, nhiên liệu sẽ gây ra ô nhiễm không khí và ảnh hưởng trực tiếp đến hoạt động cảng và khu vực xung quanh (Tạp chí giao thông 2019).

Các tính toán lan truyền các chất ô nhiễm được thực hiện vào tháng 01 và tháng 7 năm 2017 cho thấy nguồn phát thải từ tàu, thuyền có ảnh hưởng trực tiếp tới khu vực PSSAs, vịnh $\mathrm{Ha}$ Long, đảo Cát Bà và khu dân cư trên các đảo quanh khu vực các luồng hàng hải. Nồng độ các chất ô nhiễm đều ở mức dưới Quy chuẩn cho phép. Tuy nhiên, đối với thông số $\mathrm{NO}_{2^{\prime}}$ nồng độ trung bình giờ lớn nhất là 130.9 Mg/ $\mathrm{m}^{3}$, gần với mức giới hạn Quy chuẩn cho phép $\left(200 \mu \mathrm{g} / \mathrm{m}^{3}\right)$. Nồng độ $\mathrm{NO}_{2}$ cao có thể gây ảnh hưởng trực tiếp tới sức khỏe người lao động tại khu vực bến cảng và các khu vực dân cư xung quanh. Do đó, cần có những biện pháp cụ thể nhằm giảm thiểu nguy cơ gây ổ nhiễm không khí, đặc biệt với chú ý giám sát thông số $\mathrm{NO}_{2}$ theo định kỳ (Cục hàng hải Việt Nam 2018).

Cũng theo báo cáo của USAID (Sommerville 2016), do tất cả các cảng biển trên thế giới đều thu phí để bảo vệ môi trường, Việt Nam hoàn toàn có thể áp dụng cơ chế đó cho chi trả dịch vụ môi trường cho rừng ngập mặn hiện tại để tận dụng được cơ chế thu phí hiện có của cảng và việc các tàu thuyền đã quen với việc trả phí khi cập cảng. Ngoài ra, các tàu thuyền hiện nay trả ít phí hơn so với các ngành nghề khác nên cũng có thể khả thi hơn. Việc quản lí lượng thu cũng khá dễ dàng bởi có sổ sách ghi nhận số lượng tàu thuyền cập bến và rời bến. Mức phí thu thường được quyết định bởi:

- Kích cỡ của tàu

- Thời gian đậu đỗ tại cảng

- Lượng nước và các tài nguyên, dịch vụ khác mà thuyền bè sử dụng khi đỗ tại cảng.
Nghiên cứu rà soát của CIFOR cho thấy, hiện nay có 49 cảng biển tại Hải Phòng với các quy mô khác nhau và có thể là nguồn thu tiềm năng cho PFES (xem Phụ lục 1).

\subsubsection{Ngành ngân hàng}

Nhiều ngân hàng trên thế giới đang chuyển hướng đâu tư vào lĩnh vực bảo vệ môi trường và coi đó là một tài sản đảm bảo lâu dài và bền vững, đặc biệt trong bối cảnh rủi ro của suy thoái kinh tế toàn cầu và việc đầu tư sản xuất của nhiều ngành hàng đã rơi vào tình trạng bão hoà rất khó có thể gia tăng lãi suất và lợi ích (Kill 2014). Điều này lí giải việc có nhiêu ngân hàng đang tài trợ và mua tín chỉ các-bon trên toàn cầu thông qua dự án REDD+ ví dụ như World Bank, African Development Bank, ADB, International Finance Cooperation.

Tại Việt Nam, ngành ngân hàng đã có những hoạt động hỗ trợ cho các hoạt động trồng mới và bảo vệ rừng ngập mặn. Năm 2012, nhân ngày Môi trường, Ngân hàng Standard Chartered (Vietnam) Ltd đã tài trợ 21,000 USD và kêu gọi hơn 300 nhân viên để thực hiện trồng mới rừng ngập mặn tại Cần Giờ $(2,500$ cây) và Vườn quốc gia Cát Bà (1,500 cây). Hoạt động này hiện thực hóa cam kết của Ngân Hàng về bảo vệ môi trường và tạo ra các tác động tích cực đối với xã hội tại Việt Nam. Dự án trồng cây cũng thuộc chương trình "Green your flight/Xanh hóa chuyến bay của bạn" mà ngân hàng đã cam kết và thực hiện từ tháng 7 năm 2009. Chương trình này được thiết kế để bồi hoàn phát thải các-bon cho các chuyến bay mà nhân viên ngân hàng đã bay và có phát thải (Standard Chartered Bank 2012).

\subsection{Dịch vụ giảm bồi lắng và lượng bùn thải}

Theo chuẩn tắc thiết kế để đáp ứng được nhu cầu di chuyển của tàu trọng tải lớn, tuyến luồng Hải Phòng cần có độ sâu 7 đến 7.2 mét tuy nhiên nay độ sâu luồng chỉ còn khoảng 6.5 mét (Hoàng 2017). Luồng hàng hải bị bồi lắng sẽ ảnh hưởng tới lưu thông hàng hoá gây thiệt hại cho nhiều doanh nghiệp cảng biển, hãng tàu, logistic giảm lợi thế cạnh tranh kinh tế của các cảng biển Việt Nam nếu không được nạo vét, trùng tu (Hoàng 2017). Theo tính toán của 
Bảng 11. Danh sách các tàu nạo vét Hải Phòng

\begin{tabular}{llcccc}
\hline Tên tàu & Đặc điểm phương tiện & Chiều dài $(\mathbf{m})$ & Chiều rộng $(\mathbf{m})$ & Chiều cao mạn $(\mathbf{m})$ & Mớn nước(m) \\
\hline Trần Hưng Đạo & Cabin màu trắng & 91.7 & 16.0 & 6.0 & 4.6 \\
\hline HB88 & Cabin màu trắng & 49.8 & 10.0 & 4.0 & 3.4 \\
\hline HP2000 & Cabin màu trắng & 26.3 & 6.69 & 1.87 & 1.25 \\
\hline HT2700 & Cabin màu trắng & 49.0 & 9.4 & 2.0 & 1.2 \\
\hline H02 & Cabin màu ghi & 34.1 & 8.2 & 1.5 & 1.0 \\
\hline HS 05 & Cabin màu ghi & 20.0 & 5.9 & 1.0 & 0.47 \\
\hline HP 3040 & Cẩu gầu dây 7 tấn & 20.15 & 10.15 & 1.45 & 0.74 \\
\hline HP 3098 & Sà lan chở bùn & 47.8 & 9.15 & 3.1 & 2.5 \\
\hline HP 3086 & Sà lan chở bùn & 40.5 & 7.65 & 2.0 & 1.46 \\
\hline
\end{tabular}

Nguồn: Tổng Công Ty Bảo Đảm An Toàn Hàng Hải Miền Bắc 2009

Bảng 12. Nồng độ chất lơ lửng trong nước Vị trí khảo sát Trước khi nạo vét Sau khi nạo vét

\begin{tabular}{lcc}
\hline Tầng mặt & - & 208 \\
\hline Tầng giữa & - & 135 \\
\hline Tầng đáy & - & 223 \\
\hline Trung bình & 37 & 188 \\
\hline
\end{tabular}

Nguồn: Hà 2009

các chuyên gia, bồi lắng $10 \mathrm{~cm}$ tương đương với việc phải giảm 300 tấn hàng hoá có thể vận chuyển trên tàu. Tàu 10 nghìn tấn trước đây có thể lưu thông bình thường nay mất đi khoảng $20 \%$ công suất chỉ có thể chuyên chở khoảng 8 nghìn tấn (Hoàng 2017). Cũng theo báo cáo của Tổng cục hàng hải Việt Nam, khối lượng nạo vét các luồng của cảng hàng hải năm 2015 lên tới 1.1 triệu mét khối (Nguyễn 2015). Hàng năm, Hải Phòng phải chi trả cho một khoản lớn cho các công ty nạo vét bùn thải. Ví dụ, theo công văn số $1174 / K H T T$ ngày 03/12/2009 của Tổng Công ty Xây dựng đường thủy về việc các phương tiện thi công nạo vét duy tu luồng Hải Phòng; Công ty Bảo đảm an toàn hàng hải I thuộc Tổng Công ty Xây dựng đường thủy đã sử dụng 9 phương tiện để tiến hành thi công nạo vét duy tu luông Hải Phòng (Bảng 11).

Nồng độ chất lơ lửng trong nước khi nạo vét luồng tàu Nam Triệu-Hải Phòng, do Trung tâm kỹ thuật Bảo hộ lao động -Tổng liên đoàn Lao động Việt Nam thực hiện, rất khác nhau trước và sau khi nạo vét (Bảng 12).

Rừng ngập mặn, đặc biệt là quần thể thực vật tiên phong với mật độ dày, với cấu tạo đặc biệt của hệ rễ làm vật cản cho trầm tích lắng đọng đẩy nhanh quá trình bồi lắng, ngăn ngừa xói lở và giảm quá trình xâm thực bờ biển góp phần quan trọng trong ổn định dòng chảy tại các khu vực cửa sông. Beck và cộng sự (2018) cũng đã chỉ ra rằng những khu vực có và không có rừng ngập mặn có ảnh hưởng rõ ràng đến quá trình sạt lở đường bờ. Cụ thể, khả năng sạt lở đường bờ sẽ tăng lên $29 \%$ của những khu vực không có rừng ngập mặn. Với khả năng giữ đất của rừng ngập mặn, việc trồng mới và bảo vệ rừng ngập mặn có thể giúp giảm lượng bồi lắng và lượng bùn thải, giúp giảm chi phí nạo vét bồi lắng và các rủi ro kinh tế có liên quan. Kết quả điều tra và rà soát lại tài liệu thứ cấp sơ bộ của CIFOR cho thấy có 3 nhóm người mua/ người sử dụng dịch vụ tiềm năng cho dịch vụ môi trường này tại Hải Phòng (Hình 9). Việc bồi lắng bùn thải ở các luồng nước có ảnh hưởng trực tiếp tới doanh thu của các cảng và tàu bè nên việc chi trả dịch vụ môi trường rừng cho rừng ngập mặn có thể giúp mở rộng diện tích rừng ngập mặn với mục đích giảm bồi lắng. Hiện nay có nhiều công ty nạo vét bồi lắng tại Hải Phòng hoạt động từ nguồn kinh phí của UBND thành phố và theo đặt hàng của cảng cá và cảng biển. Việc đóng góp chi trả vào bảo vệ và trồng mới rừng ngập mặn có thể giúp giảm chi phí của cả UBND thành phố và các công ty này phải bỏ ra trong việc nạo vét bùn thải.

Vào 2018, trên địa bàn Thành phố Hải Phòng có 13 cảng cá, bến cá và khu neo đậu tránh trú bão cho trên 4000 tàu thuyền. Tuy nhiên, đã có nhiều công trình đang bị sa bồi, xuống cấp, ảnh hưởng trực tiếp đến môi trường, hoạt động khai thác, đánh bắt, dịch vụ hậu cần nghề cá và tiềm ẩn nguy cơ mất an toàn trong mùa mưa bão. Ví dụ, Bến cá Mắt Rồng, xã Lập Lễ (huyện 


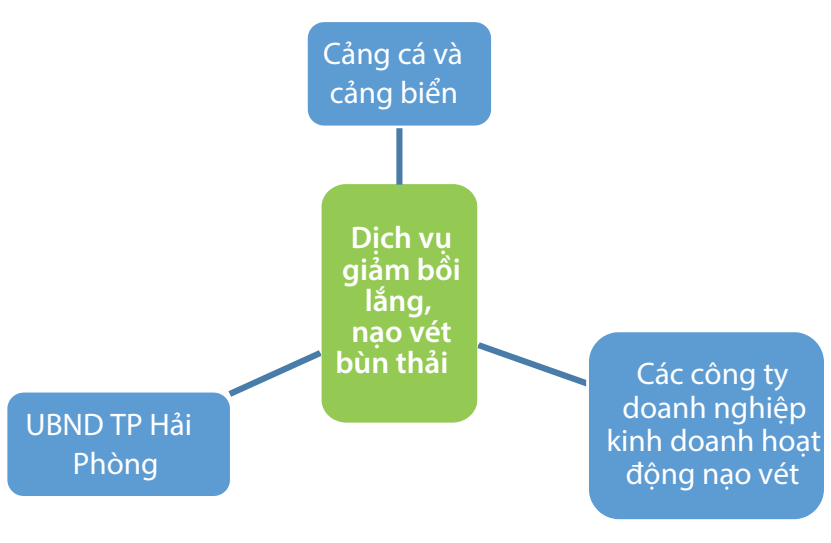

Hình 9. Các bên hưởng lợi từ dịch vụ giảm bồi lắng, nạo vét bùn thải từ RNM

Thủy Nguyên) sau gần 10 năm đưa vào sử dụng từ năm 2010, luồng lạch bến cá bị bồi lấp, nhiều đoạn chỉ rộng từ 4 đến $5 \mathrm{~m}$, sâu từ 0.2 đến 0.8 $\mathrm{m}$, gây nhiều khó khăn cho các tàu thuyền ra vào bến, ảnh hưởng xấu đến hoạt động tránh trú, neo đậu và mua bán thủy hải sản. Dựa trên chính sách hỗ trợ theo Nghị định 67 của Chính phủ, huyện Thủy Nguyên đang phát triển nhanh số lượng và công suất các tàu cá với hàng chục tàu từ hơn $800 \mathrm{CV}$ đến hơn $2250 \mathrm{CV}$. Trong đó, hơn 70 tàu công suất từ $400 \mathrm{CV}$ trở lên thường xuyên hoạt động tại bến cá mỗi khi triều cường. Chính vì vậy, việc sa bồi xuống cấp khiến ngư dân mất nhiều thời gian chờ đợi, neo đậu ngoài bến; từ đó gây khó khăn cho việc mua bán, tiếp nhiên liệu cho tàu, chuẩn bị ra khơi (Tài nguyên và Môi trường 2018a).

Ngoài ra, nhiều tuyến luồng ra vào bến cá tại Hải Phòng còn là nơi tránh trú bão của các tàu cá từ nhiều địa phương. Các tàu cá ra vào gặp nhiều khó khăn mỗi khi thủy triều xuống. Thậm chí, nhiều tàu bị mắc cạn, bị đắm, hỏng khi qua luồng, tiềm ẩn nguy cơ đe dọa an toàn hàng hải (Tài nguyên và Môi trường 2018a). Việc chi trả cho bảo vệ và trồng mới rừng ngập mặn có thể đóng góp vào việc giảm thiểu các rủi ro và ảnh hưởng tiêu cực này.

\subsection{Dịch vụ chống xói lở bờ biển}

Xói lở đường bờ chủ yếu chịu tác động lớn của hình dáng đường bờ, hướng sóng, năng lượng sóng, vận tốc dòng chảy và biên độ triều. Xói lở bờ biển là một quá trình rất phức tạp và linh động. Mức độ góp phần làm giảm xói lở của

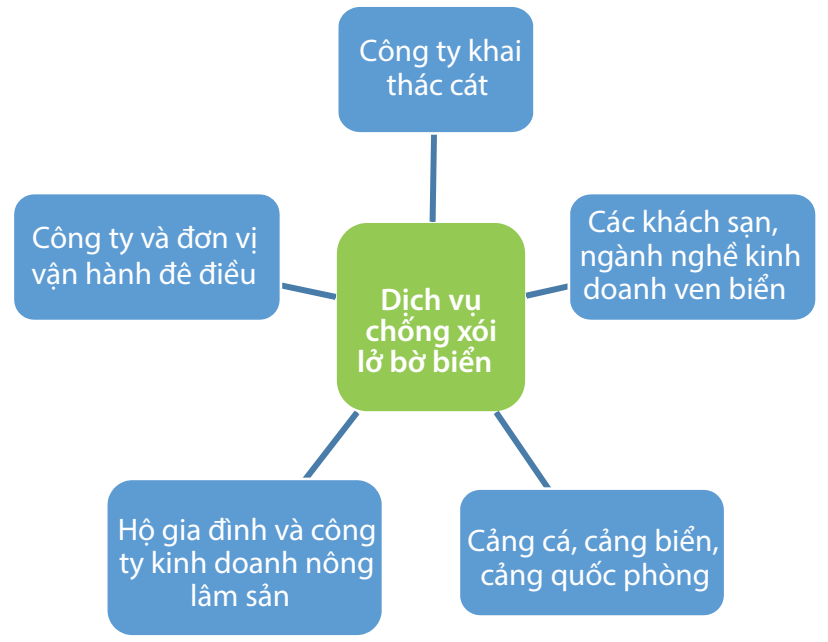

Hình 10. Các bên hưởng lợi từ dịch vụ
chống xói lở bờ biển của RNM

rừng ngập mặn có xu thế khá cục bộ. Ở một số nơi lực xói lở yếu, sự hiện diện của rừng ngập mặn ít nhiều đủ sức chống xói lở; còn ở nơi lực xói lở mạnh hơn, rừng ngập mặn có thể giúp làm giảm tốc độ xói lở một cách đáng kể. Nhưng ở những nơi năng lượng sóng ven bờ quá lớn, tác dụng của rừng ngập mặn là rất thấp hoặc không còn tác dụng phòng chống xói lở ven bờ.

Rừng ngập mặn với hệ thống rễ dày đặc dưới mặt đất giúp giữ cho đất bùn dính lại với nhau, thân cây và hệ thống rễ trên mặt đất làm giảm tốc độ dòng chảy bề mặt, từ đó làm giảm xói lở bề mặt và góp phần tích tụ phù sa ở những nơi nguồn nước có lượng trầm tích cao. Một thực tế hiện này tại RNM Cần Giờ, dọc theo Sông Lòng Tàu, lưu lượng tàu thuyền qua lại rất cao đã gây nên hiện tượng xói lở đường bờ sông là rất lớn so với các khu vực Sông Soài Rạp. Tuy nhiên, cho tới nay vẫn chưa có nghiên cứu nào đi sâu vào nghiên cứu ảnh hưởng của lưu lượng tàu thuyền đến vấn đề xói lở đường bờ sông tại khu vực Sông Lòng Tàu, mặc dù quá trình này đã và đang diễn ra tại RNM Cần Giờ.

Khi xảy ra xói lở bờ biển, rất nhiều ngành nghề kinh tế (ví dụ: cảng cá, cảng biển, cảng quốc phòng) cũng như các bên có liên quan bị ảnh hưởng, và họ có thể là người mua tiềm năng cho dịch vụ chống xói lở bờ biển của rừng ngập mặn (Hình 10). Ví dụ, khi sạt lở bờ biển, các khu khách sạn resort hoặc các cảng sẽ bị ảnh hưởng do sụt lún công trình cơ sở hạ tầng và sẽ phải bỏ ra nhiều chi phí khắc phục, sửa chữa. Việc 
sụt lún cũng gây ra mất đất của hộ gia đình và công ty đang kinh doanh trong lĩnh vực nông, lâm, thuỷ sản. Mặt khác, rất nhiều đối tượng và ngành nghề cũng đang gây xói lở bờ biển bởi các hoạt động kinh doanh của mình (ví dụ: khai thác cát; xây dựng cảng...) làm giảm diện tích rừng ngập mặn và làm tăng tốc độ xói lở đường bờ vì vùng ven bờ bị mất vành đai thực bì bảo vệ. Các khu dịch vụ công nghiệp hậu cần cảng, logistics được xây dựng phía trong bờ, gây xói lở bờ biển khu vực lân cận hoặc có thể chiếm dụng diện tích rừng ngập mặn có chức năng bảo vệ đường bờ (Tạp chí giao thông 2019) cũng cần phải có trách nhiệm chi trả cho dịch vụ này.

\subsection{Dịch vụ chắn sóng}

RNM có tác dụng làm giảm độ cao và năng lượng truyền đi của sóng. Khi triều cường, độ cao sóng biển giảm mạnh khi đi qua dải RNM, với mức biến đổi từ $75 \%$ đến $85 \%$, từ $1.3 \mathrm{~m}$ xuống $0.2 \mathrm{~m}-0.3 \mathrm{~m}$ (Phan, 2011). Một số nghiên cứu chỉ ra rằng, với $1.5 \mathrm{~km}$ chiều rộng rừng trồng 6 năm tuổi đã giảm được độ cao của sóng từ $1 \mathrm{~m}$ ở ngoài khơi xuống còn $0.05 \mathrm{~m}$ khi chạm tới bờ đầm nuôi cua và tác động của sóng lên bờ đầm là không đáng kể. Ngược lại, cũng với khoảng cách 1.5 km chiều rộng tại nơi không có RNM, sóng có độ cao $1 \mathrm{~m}$ khi vào đến bờ vẫn còn $0.75 \mathrm{~m}$ và bờ đầm bị xói lở (Yoshihiro và cộng sự 1997). Trong công trình nghiên cứu giá trị kinh tế của một số dịch vụ rừng ngập mặn, Barbier và cộng sự (2008) đã ước tính giá trị phòng hộ bão lũ của 1 km² rừng ngập mặn trong thời gian 20 năm là vào khoảng 1.6 triệu USD. Con số này lớn hơn rất nhiều so với giá trị của rừng ngập mặn từ các sản phẩm khác trên cùng diện tích và thời gian như: sản phẩm gỗ (86,400 USD), nuôi thủy sản kết hợp với rừng (211,700 USD), hoặc chuyển sang nuôi tôm công nghiệp (963,200 USD).

Tại Hải Phòng, nhiều nghiên cứu đã chỉ rõ rừng ngập mặn giúp giảm tác hại mà bão ảnh hưởng lên bờ biển và đời sống của người dân. Trong trường hợp không có rừng, hệ số suy giảm độ cao của sóng trung bình là 35\%; nhưng khi có rừng, hệ số có thể lên tới $90 \%$ đối với rừng Bần và $93 \%$ đối với rừng Bần xen Trang. Trong cơn bão, hệ số suy giảm nơi có rừng ngập mặn cũng có thể đạt tới 79\% (Bảng 13).

Các dải RNM phòng hộ ven biển đã thể hiện vai trò quan trọng trong việc làm giảm thiểu tác hại của sóng do bão gây nên, bảo vệ các đường đê bờ cùng với tài sản và sinh mạng của cộng đồng dân cư ven biển (Yoshihiro và cộng sự 1997). Nhiều ví dụ thực tế đã chứng minh vai trò bảo vệ đê điều của RNM. Khi cơn bão số 7 (29/9/2005) đổ bộ vào bờ biển Thái Thuy, Thái Bình, hơn $5 \mathrm{~km}$ bờ đê quốc gia ở xã Thái Đô, mặc dù chưa được bê tông hoá, nhưng không bị sứt mẻ vì có RNM bảo vệ. Cũng tại xã đó ở xóm Tân Bồi, 650 m đê còn lại chưa có RNM bảo vệ thì bị xói lở nghiêm trọng (Lê và cộng sự 2008). Đối với các công trình đê biển, phải coi rừng ngập mặn là một hạng mục thành phần, từ đó dành một phần kinh phí thỏa đáng để đầu

Bảng 13. Độ cao trung bình của sóng trước và sau rừng ngập mặn tại Hải Phòng

\begin{tabular}{|c|c|c|c|c|c|c|c|}
\hline Địa điểm & Thời gian & Trước rừng & Sau rừng & Mật độ & Tuổi cây & Loại cây & $\begin{array}{l}\text { Độ rộng } \\
\text { của rừng }\end{array}$ \\
\hline \multirow[t]{2}{*}{ Bàng La } & Lúc không có bão & 0.48 & 0.03 & \multirow{2}{*}{$\begin{array}{l}\text { Bần và trang } 5 \text { tuổi: } \\
\text { 17,900cây/ha } \\
\text { Trang } 6 \text { tuổi: 18,200/ } \\
\text { ha }\end{array}$} & \multirow[t]{2}{*}{$5-6$ tuổi } & $\begin{array}{l}\text { Bần xen } \\
\text { trang }\end{array}$ & \multirow[t]{2}{*}{$650 m$} \\
\hline & Lúc có bão & 1.3 & 0.27 & & & $\begin{array}{l}\text { Bần xen } \\
\text { trang }\end{array}$ & \\
\hline Đại Hợp & Lúc có bão & 1.3 & 0.27 & $\begin{array}{l}\text { Bần: 1,351 cây/ha } \\
\text { Trang: } 16,100 \text { cây/ha } \\
\text { Bần xen Trang: } \\
\text { 15,013 cây/ha }\end{array}$ & 5-6 tuổi & $\begin{array}{l}\text { Bần, Trang, } \\
\text { Bần xen } \\
\text { Trang }\end{array}$ & $670 m$ \\
\hline \multirow{2}{*}{$\begin{array}{l}\text { Vinh } \\
\text { Quang }\end{array}$} & Lúc không có bão & 0.54 & 0.05 & 1,353 cây/ ha & 8-9 tuổi & Rừng bần & $920 \mathrm{~m}$ \\
\hline & Lúc không có bão & 0.54 & 0.35 & Không có rừng & & & $920 \mathrm{~m}$ \\
\hline
\end{tabular}




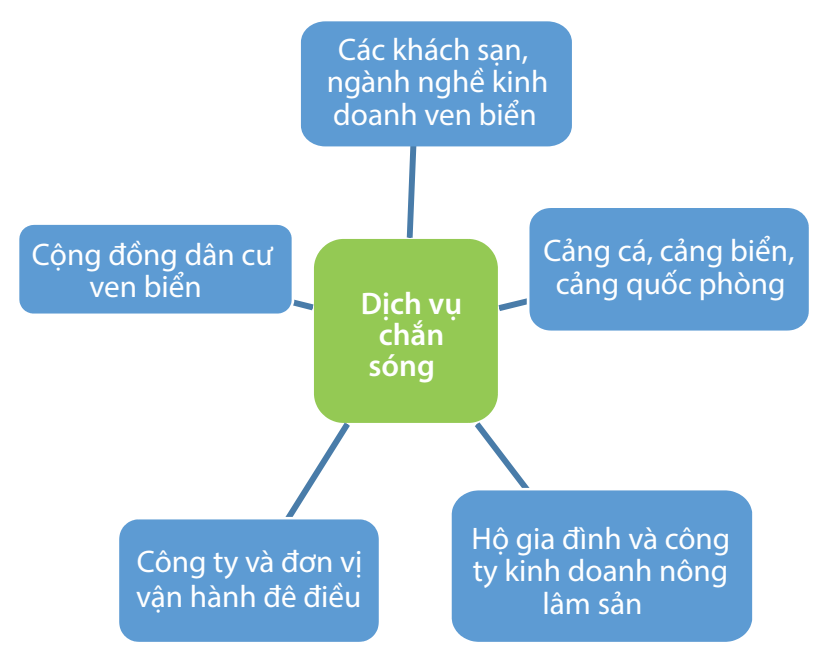

Hình 11. Các bên hưởng lợi từ dịch vụ chắn sóng của RNM

tư, chăm sóc và bảo vệ. Người mua và sử dụng dịch vụ môi trường rừng ngập mặn tiềm năng tại Hải Phòng đối với dịch vụ chắn sóng được thể hiện trong Hình 11.

\subsection{Dịch vụ cung ứng nước sạch, lọc kim loại nặng và chất ô nhiễm}

Là vùng chuyển tiếp giữa biển và đất liền, đất ngập mặn tiếp nhận các chất bẩn từ vòng tuần hoàn của thủy triều, sông và dòng chảy bề mặt của đất (Tam và Wong 1993, Tam và Wong 1996). Theo ước tính, có từ $75 \%$ đến 90\% tổng dòng vật chất liên lục bị tích luỹ ở môi trường bờ biển (Berner và Raiswell 1983). Rừng ngập mặn đã được ghi nhận là nơi chứa các chất gây nhiễm bẩn, bao gồm nitrogen (Tam và cộng sự 1995), các chất vô cơ và hữu cơ gây ô nhiễm môi trường (Maskaoui và cộng sự 2002). Do rừng ngập mặn có khả năng bẫy các chất thải lơ lửng trong cột nước hiệu quả (Wolanski và Mueller 1997) và có ái lực cao của chất hữu cơ (OM) với kim loại, nên các trầm tích rừng ngập mặn có một dung lượng lớn để tích lũy các chất gây ô nhiễm này (Harbison 1986, Tam và Wong 2000, Marchand và cộng sự 2011). Do đó, các khu vực ven biển có thể hoạt động như các bộ lọc, giữ lại các vật chất được thải ra bởi các con sông, bầu khí quyển, và đại dương trong thời gian tương đối dài (Berner 1984, Kjerfve và Magill 1989).

\subsubsection{Vết kim loại}

Vết kim loại là một thuật ngữ chung được áp dụng cho nhóm kim loại và á kim có khối lượng nguyên tử lớn hơn $5 \mathrm{~g} \mathrm{~cm}-3$ (Berkowitz và cộng sự 2008). Một định nghĩa khác về vết kim loại là trọng lượng phân tử của nó phải trên $40 \mathrm{~g}$ mol-1. Các kim loại này có thể được chia thành hai nhóm là vết kim loại thiết yếu và vết kim loại độc hại, dựa trên tầm quan trọng của chúng đối với con người và sinh vật. Nguồn gốc của kim loại xâm nhập vào hệ thống các cửa sông chủ yếu từ các nguồn điểm (ví dụ như nhà máy xử lí nước thải đô thị, các xí nghiệp công nghiệp, cống xả thải), và không phải nguồn điểm (ví dụ như dòng nước thải nông nghiệp, đô thị và xây dựng, các khu vực khai thác, bãi chôn lấp) và sự lắng đọng trong khí quyển (Hình 12) (Machado và cộng sự 2016). Các chất gây ô nhiễm thường được phát hiện ở các cửa sông ven biển và bờ biển bao gồm các vết kim loại tích lũy từ quá trình nung chảy, xử lí bùn thải, xử lí tro và nạo vét sông ngòi, sơn tẩy rửa, và các chất khử trùng, các sản phẩm ăn mòn nhà máy điện và các quy trình công nghiệp khác (Nriagu và Pacyna 1988, Al-Momani 2009).

Trong nhiều nguồn công nghiệp giải phóng vết kim loại, các quá trình luyện kim trong khai thác và nấu chảy kim loại đóng vai trò quan trọng (Larison và cộng sự 2000). Việc đốt nhiên liệu hóa thạch, đốt chất thải, thải nước thải sinh hoạt và nước thải đô thị cũng là những nguồn gây ô nhiễm các vết kim loại vào môi trường. Hầu hết các nguồn phát sinh vết kim loại đều gắn liền với các trung tâm đô thị lớn nằm dọc theo các con sông chính hoặc bờ biển trên khắp thế giới. Điều này đặc biệt đúng đối với các khu vực nhiệt đới. Trên toàn cầu, mức độ vết kim loại được ghi nhận trong trầm tích thảm thực vật rừng ngập mặn đang tăng lên hàng năm xuất phát từ sự tăng trưởng kinh tế và đô thị hóa ồ ạt (Sekabira và cộng sự 2010).

Hệ sinh thái rừng ngập mặn đón nhận một lượng đáng kể lưu lượng nước sông và nước ven biển có chứa nhiều chất dinh dưỡng, trầm tích, các vật chất lơ lửng, vết kim loại và các hydrocác-bon nguồn gốc dầu mỏ có liên quan đến nước thải đô thị, nông nghiệp đã ảnh hưởng đến chất lượng nước và trầm tích, sự sinh sản, đa dạng sinh học và chức năng của 


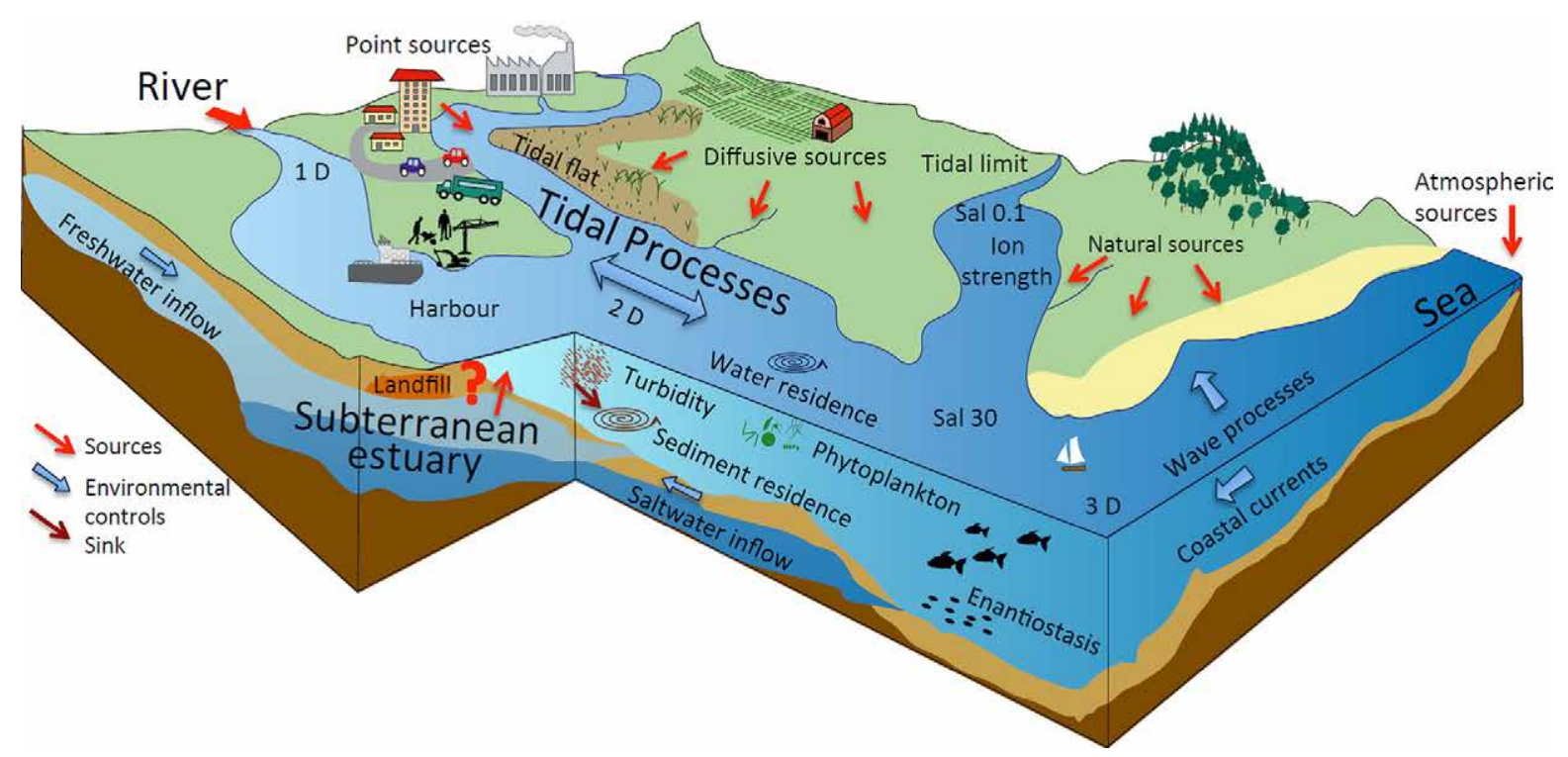

Hình 12. Các mô hình khái niệm về các thông số và quá trình vật lý, hoá học, sinh học cho hành vi của vết kim loại

Nguồn: (Machado và cộng sự 2016)

hệ sinh thái ven biển. Chẳng hạn, trong một cuộc điều tra về sự ô nhiễm vết kim loại trong quần xã sinh vật ngập mặn ở khu vực ven Biển Đỏ của Ả Rập Saudi đã ghi nhận nồng độ Đồng $(\mathrm{Cu})$ và Crom $(\mathrm{Cr})$ rất cao (Usman và cộng sự 2013). Tương tự ở Ấn Độ và Hồng Kong, sự phát triển và công nghiệp hóa mạnh mẽ đã tạo ra một mối đe dọa sinh thái đối với khu vực rừng ngập mặn gần đó, khi mà hàm lượng của các vết kim loại đã vượt ngưỡng cho chất lượng trầm tích, đặc biệt là chì $(\mathrm{Pb})$ (Defew và cộng sự 2005, Sarika và Chandramohanakumar 2008). Chính vì điều đó, tài nguyên biển và ven biển đã và đang phải chịu những sức ép rất lớn gây ra bởi sự gia tăng không ngừng của công nghiệp hóa và gia tăng dân số.

\subsubsection{Sự phân bố của vết kim loại ở rừng ngập mặn}

Nhiều khu vực ven biển đóng vai trò như một bộ phận trung gian trong việc vận chuyển nước và các vật chất từ đất liền ra biển. Sự chuyển tiếp này gây ra những thay đổi lớn về vật lý và hóa học trong cột nước. Do độ dốc địa hình ngày càng giảm đã và đang làm giảm tốc độ thoát nước và khả năng vận chuyển vật chất có trong nước, khả năng lắng đọng của các hạt vật chất dưới tác dụng của trọng lực cũng bị ảnh hưởng. Do những sự thay đổi này, một số vấn đề về việc hạt lơ lửng, bao gồm cả các vết kim loại, không thể bị suy giảm về mặt sinh học hoặc hóa học, có thể gây ra sự tích lũy cục bộ. Những chất ô nhiễm lâu dài khác bị giữ lại và lắng đọng và chỉ một phần nhỏ lượng chất này trong đất liền được đưa ra biển (Śalomons và cộng sự 1988). Ngoài ra, bùn trong rừng ngập mặn có tính chất hóa lý nội tại riêng và một dung lượng tích lũy các vật chất đáng kinh ngạc và thải ra môi trường biển gần bờ (Harbison 1986). Môi trường nước được che chở và ứ đọng của rừng ngập mặn cho phép bồi lắng các loại đất sét, bùn và các loại hạt. Vật liệu này được liên kết và ổn định bởi một thảm rễ mọc rối theo chiều ngang ngay dưới bề mặt bùn. Những hạt này cung cấp bề mặt tối ưu để vận chuyển vết kim loại. Tuy nhiên, trong thời gian ngâm nước kéo dài, sự thay đổi độ pH có thể ảnh hưởng đến sự di chuyển của kim loại ở bề mặt trầm tích và nồng độ của các ion kim loại tự do trong nước. Trong trầm tích rừng ngập mặn, vết kim loại có thể bị hấp phụ, kết tủa, đồng kết tủa và bị hấp thu bởi thực vật (Wood và Shelley 1999, Yu và cộng sự 2001). Thực vật ngập mặn có thể lưu giữ các chất gây ô nhiễm trong mô của chúng (Dunbabin và Bowner 1992), nhưng cũng giúp ích trong việc giải quyết các chất rắn lơ lửng, vận chuyển oxy từ các bộ phận bên trên mặt đất đến rễ, tạo môi trường thích hợp trong vùng bầu rễ 
(rhizosphere) và thúc đẩy một loạt các phản ứng hóa học và sinh hóa, giúp tăng cường sự lưu giữ kim loại (Kadlec và cộng sự 2000). Mức độ sản xuất ra một lượng lớn sulfide đã gia tăng việc kết tủa và cố định các vết kim loại trong rừng ngập mặn (Ambus và Lowrance 1991, Dunbabin và Bowner 1992). Ngược lại, sự mất oxy cấp tiến (Radical Oxygen Loss -ROL) của thực vật rừng ngập mặn sẽ điều hòa khí quyển và tăng sự linh động của các vết kim loại do quá trình oxy hóa và hòa tan sulfide. ROL cũng sẽ gây ra sự hình thành các mảng bám của Sắt (Fe), chính các mảng đã cung cấp thêm một số tâm liên kết nhằm bổ sung vết kim loại trên bề mặt rễ cây (Cheng và cộng sự 2014). Rễ cây rừng ngập mặn thường hoạt động như một hàng rào vật lí, có tác dụng giữ lại hầu hết các vết kim loại và hạn chế sự vận chuyển các vết kim loại lên các bộ phận khác nằm trên mặt đất của cây (Yim và Tam 1999).

Dựa trên cơ sở các nghiên cứu khoa học của thế giới, đánh giá chung lượng dầu thải xuống các vùng nước hàng năm (đặc biệt tại các vùng biển) được ước tính: 73\% từ hoạt động tàu biển, $21 \%$ từ sự cố hàng hải và $6 \%$ từ các nguồn khác. Trong đó, việc khai tác hoạt động các loại tàu, sà lan là ngyên nhân chủ yếu gây ô nhiễm dầu. Có đến $90 \%$ các vụ việc tràn dầu dưới 7 tấn xảy ra trong quá trình nhận, trả hàng, tiếp nhận nhiên liệu và thường xảy ra trong cảng hoặc tại bến nhận/trả hàng (Cổng thông tin điện tử Bộ Giao thông Vận tải 2011).

Theo kết quả quan trắc của Viện Tài nguyên và Môi trường biển năm 2016, nước ở vùng cửa sông, vùng ven biển Hải Phòng đều gia tăng mức độ ô nhiễm so với năm 2015, và mức độ ô nhiễm là do nhiều ngành và họ cũng chính là những người sử dịch vụ môi trường rừng tiềm năng (Bảng 14, Nguyễn 2017).
Tại vùng biền ven bờ Hải Phòng, $60-70 \%$ các nguồn thải xuất phát từ lục địa ra biển thông qua các của sông Thái Bình, Cấm và Bạch Đằng. Trong đó, chủ yếu là các chất ô nhiễm hữu cơ (chiếm khoảng 53-63\%), dinh dưỡng ni-tơ và phốt-pho (chiếm khoảng 27-48\%). Không những thế, tại những khu vực ven biển có nhiều các khu công nghiệp như Đình Vũ, An Dương, Đồ Sơn ..., khá cao nồng độ dầu và xyanua trong đất ngấm ra sông, biển (Nguyễn 2017).

Ngoài ra, tại các khu du lịch, nước thải chưa qua xử lý, được đổ thẳng ra biển bởi các nhà hàng dịch vụ ăn uống, gây ô nhiễm môi trường tại các khu du lịch như khu Đồ Sơn 2, khu dịch vụ hậu cần nghề cá đảo Cát Bà .... Thêm vào đó, nhiều nguồn ô nhiễm bị đổ ra biển từ các kênh mương như cống sinh hoạt Nam Đông, mương An Kim Hải đổ ra khu vực biển Đình Vũ, cống $C 1$ tiếp nhận nước thải từ các cơ sở sản xuất chế biến hải sản trên địa bàn quận Dương Kinh,... (Nguyễn 2017).

Dựa trên các kết quả nghiên cứu tiền khả thi trên, nhóm nghiên cứu đã xác định được người sử dụng và người mua tiềm năng cho dịch vụ nước sạch và lọc kim loại nặng mà rừng ngập mặn đem lại tại Hải Phòng (Hình 13).

\subsubsection{Công nghiệp đóng tàu}

Trong một báo cáo của hội đồng OECD (2010) đánh giá các yếu tố tác động tới môi trường từ hoạt động đóng tàu:

Hoạt động tác động tới môi trường trực tiếp nhất là tại các khu xưởng, trong đó ngoài việc đóng mới tàu còn có cả dịch vụ bảo dưỡng và sửa chữa. Việc đóng tàu bao gồm:

Bảng 14. Danh sách các bên xả thải tại các vùng ven biển tại Hải Phòng

\begin{tabular}{ll}
\hline Ngành & Mức độ xả thải và ô nhiễm \\
\hline Nuôi trồng thủy sản & $\begin{array}{l}\text { Tỷ lệ chất ô nhiễm (chất rắn lơ lửng và phenol) vượt giới hạn cho phép (GHCP) } \\
\text { tăng từ 10.8\% lên 20.7\%. }\end{array}$ \\
\hline Giao thông vận tải, tàu thuyền & $\begin{array}{l}\text { Tỷ lệ chất ô nhiễm (chất dinh dưỡng và phenol) vượt GHCP tăng từ 9.4 \% lên } \\
11.4 \%\end{array}$ \\
\hline Du lịch, bãi tắm & Tỷ lệ chất ô nhiễm, vượt GHCP tăng từ 8.7\% lên 15.9 \\
\hline Sản xuất nông nghiệp & Vùng cửa sông Hải Phòng có hàm lượng thuốc trừ sâu cao 3-4 lần so với nơi khác \\
\hline
\end{tabular}

Nguồn: Nguyễn 2017 


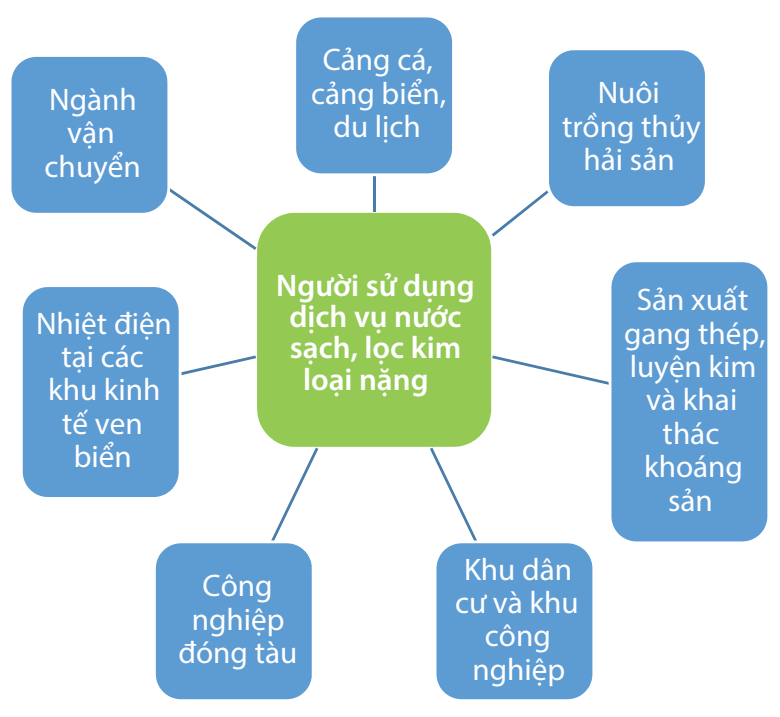

Hình 13. Các bên được hưởng lợi từ dịch vụ cung cấp nước sạch và lọc kim loại của RNM

- Xử lý các vật liệu thô, xử lý vật liệu thép thô

- Lắp ghép các phần thành các khối

- Hàn nối các khối thành cấu trúc của con tàu

- Lắp đặt lớp vỏ ngoài và các thiết bị điện tử

- Lắp đặt ngoại thất

Các hoạt động bảo trì và sửa chữa:

- Làm sạch và xử lý lớp vỏ tàu

- Thay dầu máy

- Dịch vụ bảo dưỡng máy móc và các thiết bị khác

Theo đó, các hoạt động có lo ngại ảnh hưởng cao nhất tới môi trường bao gồm:

- Các hoạt động xử lý kim loại, trong đó có cắt, hàn, mài nhiệt kim loại. Các công việc xử lý kim loại bao gồm cắt, ép, khoan, cán nghiền, mài và lắp ghép kim loại có thể dẫn tới ô nhiễm không khí. Ngoài ra công việc xử lý kim loại cũng phát thải ra dầu mỡ, dầu cắt, vv... cùng với bụi kim loại hòa vào trong nước hình thành ô nhiễm nước thải. Việc cắt, hàn kim loại sử dụng nhiên liệu Oxyfuel-Gas hay cắt nhiệt tạo ra bụi mịn $\mathrm{PM}$ và các khí thải độc hại bởi khói đốt (fume). Ngoài ra, nếu như độ tinh khiết của khí hàn oxy không cao (không đạt trên 99.5\%) thì hiệu suất giảm, dẫn tới cần nhiều hơn thời gian cắt - hàn, từ đó tăng khí phát thải (EPA 2005). Hàn plasma sử dụng dòng điện để nung nóng kim loại. Trong quá trình thực hiện, cắt plasma giải phóng một lượng lớn khí oxi hóa kim loại và các chất thải khác.
- Các hoạt động xử lý bề mặt vỏ, trong đó có bào, ghép vỏ, sơn.

- Các hoạt động bảo dưỡng và xử lý, như dọn dẹp thân và đáy tàu.

- Hợp chất thiếc hữu cơ (Tributyltin - TBT) được tìm thấy trong sơn chống gỉ được sử dụng trong ngành công nghiệp đóng tàu. Mặc dù chất TBT đã được liệt vào danh sách các chất độc hại từ 2008 (Con người và thiên nhiên 2008) nhưng những tồn dư chất vẫn còn được tìm thấy và có những ảnh hưởng nhất định (Ngô và Nguyễn 2017). Điểm nóng (hot - spots) của hợp chất hữu cơ thiếc TBT thường tập trung tại các khu vực cảng thương mại và các bến xưởng đóng/sửa chữa tàu. (Bray và Langston 2006). Tributyltin (TBT), cũng như các sản phẩm phân hủy $D B T$ và $M B T$, hiện là chất gây ô nhiễm toàn cầu ở khắp mọi nơi trong môi trường nước biển và nước ngọt toàn cầu do sử dụng rộng rãi trong sơn chống bẩn trên tàu (WWF 2006). Các khu vực có hàm lượng TBT đặc biệt cao trong nước, trầm tích và các loài động vật hoang dã, hay còn gọi là "điểm nóng TBT," thường tập trung tại các cảng thương mại, nhà máy đóng tàu, đường vận chuyển, bến du thuyền.... Việc các chất độc hại này chảy theo nguồn nước ra biển không chỉ ảnh hưởng đến chất lượng nước mà còn có ảnh hưởng nghiêm trọng đến sức khỏe của con người. Việc bảo vệ và phát triển rừng ngập mặn để giảm thiểu tác động của nguồn ô nhiễm này đang ngày càng trở nên quan trọng và cấp bách.

Tính đến năm 2016, toàn thành phố Hải Phòng có 172 đơn vị đóng mới và sửa chữa tàu biển (bao gồm cả những đơn vị hoạt động đa ngành) tập trung tại các khu công nghiệp ven biển, trong đó có 8 doanh nghiệp Trung ương, 164 doanh nghiệp ngoài nhà nước với tổng số lao động tham gia là 9,300 (Trần và Đỗ 2018). Các loại tàu đóng tại Hải Phòng khá đa dạng với nhiều chủng loại như: tàu hàng khô (từ 6,500 DWT đến 53,000 DWT), các tàu chuyên dụng (tàu lai dắt, tàu kéo, tàu đầy, tàu hoa tiêu, tàu nghiên cứu, tàu hút bùn), tàu chở dầu, tàu công-ten-nơ, tàu chở ô tô đến 150,000 DWT. Các sản phẩm đóng tàu được xuất khẩu đến nhiều nước, gồm cả thị trường Nhật Bản, Anh và Hà Lan. Tỷ lệ "nội địa hóa" sản phẩm tàu đóng mới đạt tỷ lệ tương đối cao ở mức 50-70\%. Bên cạnh đó, công nghiệp phụ trợ cho ngành đóng và sửa chữa tàu cũng phát triển 
khá mạnh, ví dụ như: sơn tàu biển, sản phẩm vật liệu hàn, sản phẩm nội thất tàu thủy, sản phẩm cơ khí tàu thủy (Trần và Đỗ 2018).

Theo đại diện của Công ty tàu thủy SBIC², ngành công nghiệp đóng tàu đóng vai trò quan trọng trong việc cung cấp các phương tiện, thiết bị kỹ thuật phục vụ vận tải hàng hóa, hành khách, công nghiệp quốc phòng, dầu khí và công nghiệp thủy hải sản (Thuỳ 2019). Tuy nhiên, trong 2 năm vừa qua, ngành này còn đối mặt với nhiều khó khăn do ảnh hưởng của khủng hoảng ngành cơ khí đóng tàu thế giới trong những năm qua và nhiều nguyên nhân khác. Ví dụ, Tổng công ty Công nghiệp tàu thủy - SBIC (chiếm khoảng 70\% năng lực đóng tàu của Việt Nam) đã mất khả năng thanh toán và hiện đang thực hiện Tái cơ cấu toàn diện theo chỉ đạo của Bộ Chính trị, Chính phủ và Bộ Giao thông vận tải từ năm 2010 đến nay (Thuỳ 2019). Các công ty đóng tàu thành viên hiện hầu như không có các khách hàng lớn do các công ty vận tải hàng hải trong nước cũng đang gặp nhiều khó khăn trong cạnh tranh cũng như việc tìm kiếm nguồn vốn để đầu tư mở rộng đội tàu. Quỹ việc làm hàng năm của các đơn vị đang giảm dần không phát huy được năng lực cơ sở hạ tầng đã đầu tư lớn từ những năm trước đồng thời các doanh nghiệp đóng tàu cũng đang gặp phải khó khăn về tài chính do các khoản nợ đầu tư lớn tại các Ngân hàng chưa được tái cơ cấu dẫn đến việc vay vốn ngân hàng gần như là không thể (Thuỳ 2019). Tổng công ty và các đơn vị cũng không thể mở thủ tục bảo lãnh thực hiện hợp đồng theo thông lệ quốc tế với các hợp đồng đóng tàu thương mại cho chủ tàu nước ngoài. Nhiều chuyên gia, cán bộ thiết kế-kỹ thuật, công nhân lành nghề cũng chuyển ra khỏi Tổng công ty do số lượng thi công các tàu xuất khẩu giảm sút nhiều, khiến cho việc quỹ việc làm liên tục giảm sâu hàng năm. Năng lực quản lý và tổ chức sản xuất, quản lý kinh tế ở phần lớn các nhà máy đóng tàu vẫn còn chưa đáp ứng yêu cầu (Thuỳ 2019).

Kết quả chuyến đi khảo sát của CIFOR tại Hải Phòng cũng cho thấy, số lượng các doanh

2 Hiện nay, Tổng công ty Công nghiệp Tàu thủy - SBIC (tiền thân là Tập đoàn Công nghiệp Tàu thủy - Vinashin) có 4 đơn vị công ty con đóng tàu hoạt động tại Hải Phòng bao gồm: Công ty đóng tàu Bạch Đằng; Công ty đóng tàu Phà Rừng; Công ty đóng tàu Sông Cấm và Công ty đóng tàu Nam Triệu nghiệp đóng tàu bị đóng cửa tại Hải Phòng ngày càng tăng do kinh phí hạn hẹp và không thể trả nợ. Ngoài ra, các khu neo đậu của công tàu thủy bị bồi đắp rất nhanh do tác động của việc xây dựng của khu đô thị Vinhomes Imperia dẫn đến mất mặt bằng sản xuất. Đồng thời việc xây dựng cầu Hoàng Văn Thụ khiến các tàu trên 3,000 tấn không thể vào xưởng của một số công ty.

\subsection{4 Ô nhiễm nước từ ngành vận tải biển}

Tại Cát Bà, ô nhiễm môi trường biển có thể xảy ra do nhiều nguyên nhân (đô thị hóa, du lịch, dịch vụ) nhưng vận tải biển là nguyên nhân lớn nhất. Các sự cố tai nạn tàu thuyền chiếm đến khoảng 12\% nguồn gây ô nhiễm và thường gây ra hậu quả sinh thái nặng nề, trong khi quản lí chất thải từ tàu biển không được kiểm soát và đặt vào mục tiêu phát triển. Vấn đề ô nhiễm ngày càng nghiêm trọng khi việc vận chuyển hoá chất nguy hại như xăng dầu, mazut, diesel, khí hoá lỏng, dầu thực vật, than đá đều gia tăng nhanh chóng (Cục Hàng hải Việt Nam 2015).

Sự hình thành và hoạt động của các trung tâm logistics có thể gây ra những hệ lụy trực tiếp hoặc gián tiếp ảnh hưởng xấu đến môi trường. Hầu hết phương tiện vận chuyển hàng hóa đều kéo theo sự gia tăng chất thải. Ngành vận tải biển đang là ngành có nhiều nguy cơ tiềm ẩn gây ô nhiễm môi trường nước biển nhiều nhất, do sự gia tăng về số lượng cảng biển, mật độ tàu thuyền, do các vụ tràn dầu trong quá trình nhận, trả hàng, tiếp nhận nhiên liệu, và do việc sửa chữa, vứt bừa bãi các loại chất thải dính dầu mõ̃. Trong bối cảnh Việt Nam, việc gia tăng nhu cầu vận tải than sẽ làm gia tăng vận tải biển trong tương lai và tạo áp lực lên chất lượng môi trường nước biển.

Theo dự báo trong Quy hoạch điều chỉnh "Quy hoạch phát triển ngành Than Việt Nam đến 2020, có xét triển vọng đến 2030" (phê duyệt theo Quyết định số 403/2016/QĐ-TTg ngày 14/3/2016 của Thủ tướng Chính phủ - QH 403/2016) nhu cầu than của Việt Nam ngày càng tăng cao (Bảng 15, Nguyễn 2019).

Nguồn than trong nước chỉ đáp ứng được khoảng một nửa nhu cầu đó (Minh 2017). Vi vậy, trong tương lai Việt Nam phải nhập khẩu lượng lớn than từ nước ngoài về để đáp ứng được nhu cầu ngày càng cao này. Theo dự kiến, 
riêng Tập đoàn Điện lực Việt Nam (EVN) sẽ nhập khẩu khoảng gần 5 triệu tấn than trong năm 2017. Con số này sẽ tăng lên 11 triệu tấn vào năm 2020 và 19 triệu tấn vào năm 2025, tương đương $1 / 3$ tổng lượng than nhập khẩu của Việt Nam (Minh 2017). Điều này cho thấy Tập đoàn Điện lực Việt Nam là 1 trong số những doanh nghiệp tiêu thụ than lớn nhất cả nước, và ngành nhiệt điện sử dụng năng lượng hóa thạch là than đá ngày càng gia tăng. Trong khi đó, nhà nước và nhiều tỉnh (ví dụ Quảng Ninh) và nhiều tập đoàn (ví dụ Vinacomin) đang lên kế hoạch để chuyển đổi sang vận chuyển than bằng đường biển thay vì đường bộ (Vietnamnews 2016).

Sở dĩ các tập đoàn lớn hay doanh nghiệp chuyển đổi hình thức vận chuyển than bằng đường bộ sang đường biển bởi vì: các hình thức vận chuyển thông thường còn rất nhiều hạn chế về năng lực chuyên chở, và điều kiện đường xá Việt Nam không thuận lợi để ô tô có thể vận chuyển khối lượng hàng hóa cực lớn. Nhược điểm này có thể được khắc phục với tàu chở hàng hóa. Hiện nay, có rất nhiều các loại tàu biển lớn ra đời do được di chuyển trên những cung đường tự nhiên và có thể giúp các cá nhân các doanh nghiệp dễ dàng chuyển một khối lượng hàng hóa gấp hàng trăm, thậm chí là vài nghìn lần, so với vận chuyển bằng các hình thức khác. Khi sử dụng hình thức vận chuyển than bằng đường biển, các cá nhân và doanh nghiệp có thể tiết kiệm được một khoản đáng kể cho chi phí vận chuyển, bởi mỗi một chuyến hàng bạn có thể vận chuyển được một khối lượng hàng hóa lớn nên chi phí cũng từ đó mà giảm theo. Nếu tính toán một cách chi tiết nhất, giá thành khi vận chuyển than bằng đường biển rẻ hơn rất nhiều lần so với các hình thức khác (Vận tải đường biển 2018). Bảng 16 cũng thể hiện các kế hoạch rõ ràng của nhà nước về việc vận chuyển than bằng đường biển.

Theo số liệu của Tổng công ty tư vấn và thiết kế GTVT - CTCP năm 2015 tại Hải Phòng chỉ vận chuyển than tại 9 bến trên sông Cấm (Mipec, Thượng Lý, Đài Hải, Hải Đăng, Total Gas, Dầu Khí Hải Linh, K99, Petec, Cầu 19/9). Tuy nhiên theo Quyết định 1037/QĐ-TTg ngày 24/6/2014 về việc phê duyệt Điều chỉnh quy hoạch phát triển hệ thống cảng biển đến năm 2020, định

Bảng 15. Dự báo nhu cầu than đến năm 2035

\begin{tabular}{lcccc}
\hline & 2020 & 2025 & 2030 & 2035 \\
\hline Nhu cầu than cả nước (triệu tấn) & 81.3 & 110.9 & 144.7 & 153.1 \\
\hline Trong đó, nhu cầu than cho sản xuất điện (triệu tấn) & 59.5 & 86.0 & 119.4 & 127.5 \\
\hline
\end{tabular}

Nguồn: Nguyễn 2019

Bảng 16. Quy hoạch loại, cỡ tàu vận tải theo Quyết định số 1517/QD-TTG ngày 26/08/2014 về phê duyệt quy hoạch phát triển vận tải biển Việt Nam đến năm 2020, định hướng đến năm 2030

\begin{tabular}{lcc}
\hline & Tuyến quốc tế & Tuyến nội địa \\
\hline 1. Tàu hàng rời & $30,000-200,000 D W T$ & $1,000-10,000 D W T$ \\
\hline $\begin{array}{l}\text { 1.1 Nhập than cho nhà máy nhiệt điện, quặng cho nhà máy } \\
\text { liên hợp gang thép }\end{array}$ & $100,000-200,000 D W T$ & $5,000-10,000 D W T$ \\
\hline $\begin{array}{l}\text { 1.2 Xuất khẩu than, quặng, alumin, nhập phân bón và } \\
\text { clinker }\end{array}$ & $30,000-50,000 D W T$ & \\
\hline
\end{tabular}

Nguồn: Thủ tướng Chính phủ 2014

Bảng 17. Phân bổ hàng hóa 2020 và 2030 qua cảng vụ Hải Phòng

\begin{tabular}{|c|c|c|}
\hline & 2020 & 2030 \\
\hline Khu vực bến sông Cấm & 2 triệu tấn hàng rời trong đó có than & 2 triệu tấn hàng rời trong đó có than \\
\hline Khu bến Đình Vũ & 2 triệu tấn hàng rời trong đó có than & 1 triệu tấn hàng rời trong đó có than \\
\hline
\end{tabular}


hướng 2030, đã có sự điều chỉnh về phân bổ hàng hoá giữa các bến trong cảng Hải Phòng khi khu bến Đình Vũ cũng đã được phân bổ 2 triệu tấn hàng rời trong đó có than (Bảng 17). Việc vận chuyển than ở các cảng vụ Hải Phòng thay đổi từ khu vực bến nội địa là bến sông Cấm sang khu bến quốc tế Đình Vũ cũng phù hợp với xu thế dự đoán trong tương lai, khi Việt Nam phải nhập khẩu lượng than lớn từ quốc tế.

\subsubsection{Cảng biển/cảng cá}

Theo định nghĩa trong Luật Thủy sản năm 2017, cảng cá là cảng chuyên dụng cho tàu cá, bao gồm vùng đất cảng cá và vùng nước cảng cá. Vùng đất cảng cá là khu vực được giới hạn để xây dựng cầu cảng, kho, bãi, nhà xưởng, trụ sở, cơ sở dịch vụ, hệ thống giao thông, thông tin liên lạc, điện, nước và công trình phụ trợ khác phục vụ cho hoạt động của cảng cá. Vùng nước cảng cá là vùng nước được giới hạn để thiết lập vùng nước trước cầu cảng, vùng quay trở tàu, khu neo đậu, khu chuyển tải, luồng vào cảng cá và công trình phụ trợ khác (Quốc hội Việt Nam 2017). Hàng năm trên địa bàn TP Hải Phòng, các cơ sở dịch vụ hậu cần thủy sản phục vụ khoảng 12,000 lượt tàu; tổ chức 150 tàu dịch vụ hậu cần thủy sản trên biển nhằm hỗ trợ các tàu đánh bắt tăng thời gian bám biển, giảm chi phí, nâng cao hiệu quả khai thác (Tài nguyên và Môi trường 2018a).

Theo Hà (2009), mặc dù cảng biển là đầu mối quan trọng giúp sự phát triển kinh tế, chính trị và xã hội của toàn quốc nói chung và Hải Phòng nói riêng, quá trình xây dựng và hoạt động của các cảng biển cũng gây ra nhiều tác động tiêu cực mà nếu không được quan tâm đầy đủ sẽ ảnh hưởng xấu đến môi trường vùng cảng và thậm chí cả vùng biển của đất nước. Hệ thống cảng biển của nước ta phân bố dọc bờ biển, mọi sự ô nhiễm môi trường đều gây ra hậu quả lan truyền rất lớn dọc theo bờ biển từ Bắc xuống Nam hoặc ngược lại (tùy theo chế độ hải lưu mùa hè và mùa đông). Do biên độ triều lớn nên các cảng vùng cửa sông nguồn ô nhiễm sẽ được dòng triều đưa đến toàn bộ vùng cửa sông. Sự lan truyền ô nhiễm bụi và khí độc theo hướng gió của hai mùa cũng cần được quan tâm để giảm thiểu sự ảnh hưởng đến các đô thị hoặc khu dân cư gần cảng (Hà 2009).
Việc xây dựng và vận hành cảng cũng đã ảnh hưởng nghiêm trọng đến hệ sinh thái rừng ngập mặn (Bảng 18).

Cục Hàng hải Việt Nam (2015) cũng đã nêu rõ ảnh hưởng của hàng hải tới môi trường biển và nước bao gồm:

- Các sự cố hàng hải, mắc cạn và đập bờ;

- Tràn dầu, rò rỉ từ bồn thùng chứa nhiên liệu sẽ (i) ảnh hưởng tới ngành đánh bắt nuôi trồng thủy hải sản, (ii) ảnh hưởng đến ngành du lịch khi nước bẩn và bốc mùi, (iii) ảnh hưởng tới hệ sinh thái rừng ngập mặn, cỏ biển, vùng triều bãi cát, đầm phá, các rạn san hô và, nghiêm trọng hơn, giảm khả năng sức chống đỡ, tính linh hoạt và khả năng khôi phục của các hệ sinh thái;

- Sự cố liên quan đến thùng, bồn chứa các chất lỏng, chất rắn độc hại như thuốc trừ sâu hóa chất độc hại

Ngoài ra, dầu trôi nổi còn làm hỏng máy móc, thiết bị khai thác tài nguyên và vận chuyển đường thủy, làm ảnh hưởng đến hoạt động của các cảng cá, cơ sở đóng mới và sửa chữa tàu biển.

\subsection{6 Ô nhiễm nước từ ngành gang thép}

Trong các nhà máy luyện gang thép bằng phương pháp truyền thống (sử dụng oxy trong lò đốt), nước làm lạnh thường bị nhiễm kim loại nặng và chất bôi trơn nên không được tái sử dụng, sau được thải bỏ ra bên ngoài cùng với nước thải từ các nguồn khác nhau. Trung bình sản xuất một tấn sản phẩm sẽ thải ra khoảng $80 \mathrm{~m}^{3}$ nước thải. Nước thải này có nhiệt độ rất cao vì được hòa trộn nước làm mát. Thành phần của nước thải từ ngành luyện gang thép rất khó xử lý bao gồm nhiều hoá chất độc hại như phenol, xyanua, ammonia, dầu, kim loại nặng, và một số chất hữu cơ khác (QCVN, n.d).

Trong quá trình sản xuất gang thép phát sinh nguồn chất thải gồm nước thải, khí và bụi thải, chất thải rắn. Trong đó, có 2 nguồn nước thải: Nước dùng để pha chế các loại hóa chất công nghiệp, để tẩy, rửa kim loại, sơn mạ màu; Nước được sử dụng để tản nhiệt các thiết bị và sản phẩm. Khi bị thải ra, lẫn trong nước là các chất, dầu, mỡ dư thừa, bụi cặn, oxit các kim loại nặng, ... gây ô nhiểm (Nghiêm và Bùi 2016). Theo số liệu thống kê (Nguyễn và Nguyễn 2017), cứ mỗi tấn thép thô sản xuất bằng công 


\section{Bảng 18. Tác động của việc xây dựng và vận hành cảng biển}

\begin{tabular}{|c|c|}
\hline & Tác động đến môi trường và rừng ngập mặn \\
\hline $\begin{array}{l}\text { Quá trình xây } \\
\text { dựng cảng, } \\
\text { cẩu tàu, bến } \\
\text { bãi }\end{array}$ & 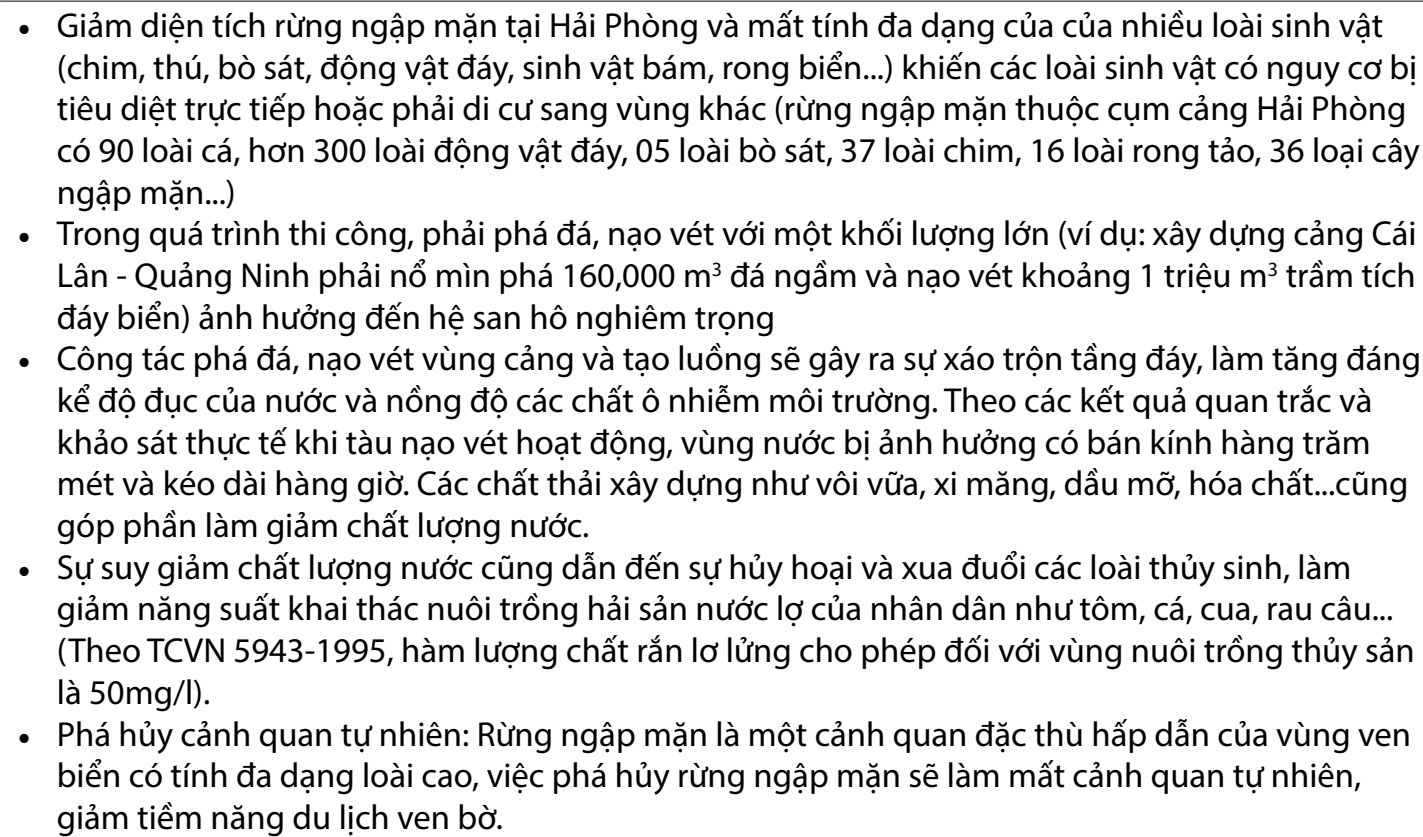 \\
\hline $\begin{array}{l}\text { Quá trình vận } \\
\text { hành khai thác } \\
\text { cảng }\end{array}$ & 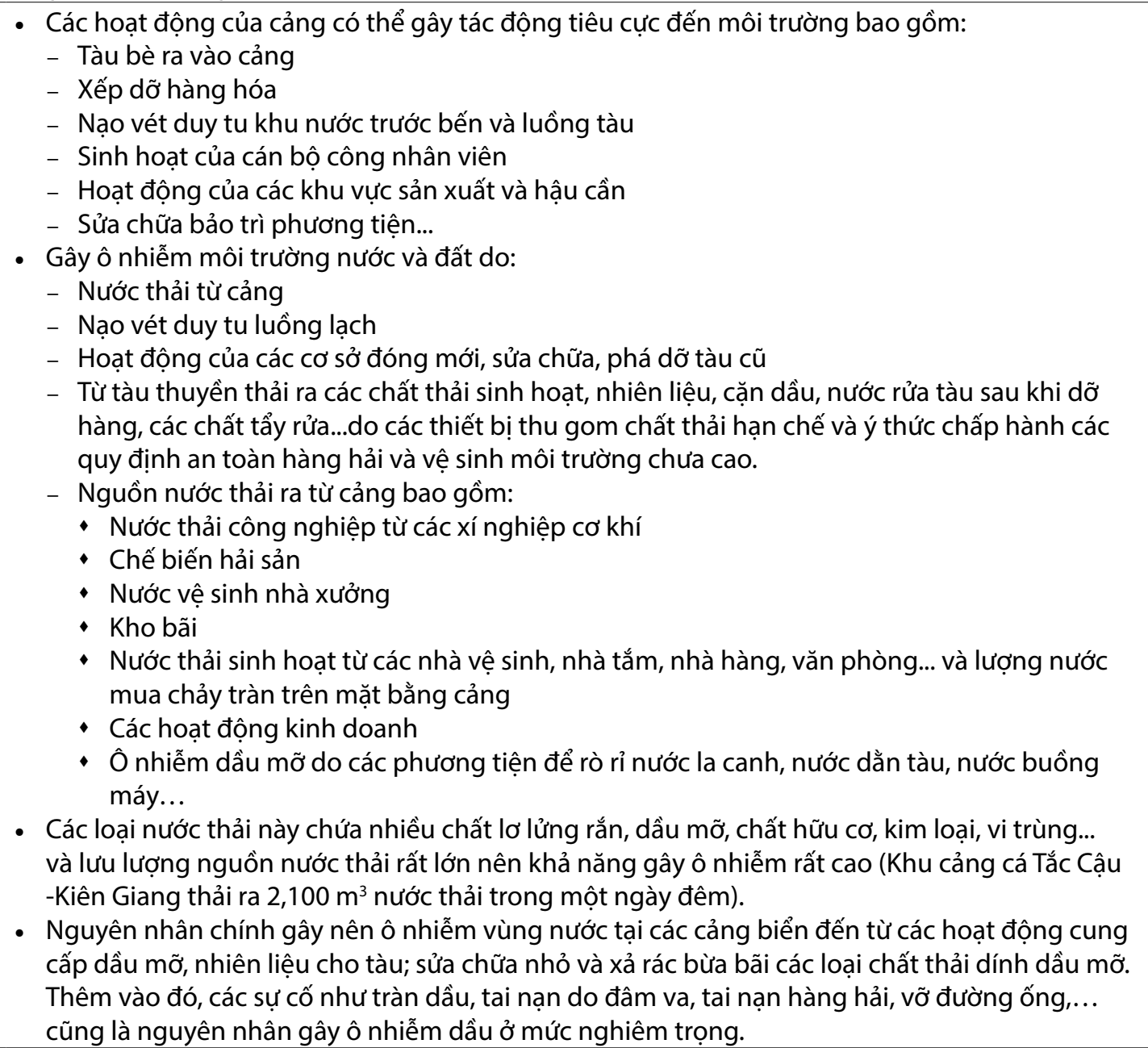 \\
\hline
\end{tabular}

Nguồn: Hà 2009, Tạp chí giao thông 2019, Cổng thông tin điện tử Bộ Giao thông Vận tải 2011 
nghệ lò cao sẽ phải thải ra hơn 500kg chất thải rắn $(x i)$, $3 m^{3}$ nước thải độc hại.

Hiện tại với ngành thép có thông tư Số: 03/2014/TT-BCT ngày 25 tháng 01 năm 2014 Quy Định về Công Nghệ, Thiết bị Sản xuất Gang, Thép. Trong đó có các quy định về môi trường như quy định xử lý khí thải (QCVN 51:2013/BTNMT), chất thải rắn (QCVN 07:2009/ BTNMT), bùn thải (QCVN 50:2013/BTNMT) và nước thải (QCVN 52:2013/BTNMT). Tuy nhiên, nhiều trường hợp không làm theo quy định, ví dụ như ô nhiễm nhà máy gang thép Vạn Lợi (Hải 2014), công ty thép Việt Nhật (Thu 2018), VSC-POSCO và VINAPIPE xả nước thải ra kênh Tân Hưng Hồng, trực tiếp chảy ra sông Cấm, sông Rế - là nguồn cấp nước cho thành phố Hải Phòng (Thuý 2015).

\subsubsection{Công ty xăng dầu}

Theo nghiên cứu của Cục Hàng hải Việt Nam (2015), các chất độc hại tại cảng B12 cùng với kho chứa lớn nhất Việt Nam thuộc Tổng Công ty Xăng dầu Việt Nam với hàng triệu tấn hàng xăng dầu, mazut, diesel, khí hoá lỏng nhựa đường là nguồn gốc gây hại tới môi trường và đa dạng sinh học biển. Ngoài ra, hàng triệu tấn dầu thực vật qua Cảng Cái Lân, hàng triệu tấn than đá nhập khẩu và xuất khẩu qua Cảng Cẩm Phả cũng là các tác nhân có nguy cơ gây hại tới môi trường khi có sự cố, hàng hóa tại các cảng trung chuyển trên vịnh Lan Hạ-Cát Bà.

“Đầu tháng 8 năm 2019, Tổng công ty Hàng hải VN (Vinalines) vừa gửi văn bản đề xuất Bộ GTVT đầu tư xây dựng cụm cảng, tổng kho xăng dầu và khí hóa lỏng với diện tích khoảng 400-450 ha tại đảo Cái Tráp và khu vực cảng Lạch Huyện (Cát Hải, Hải Phòng)." (Bộ Giao thông vận tải 2019)

Theo đại diện Vinalines, hiện nhóm hàng lỏng đang chiếm khoảng 5-7\% tổng lượng hàng thông qua cảng Hải Phòng. Đặc biệt trong 2 năm gần đây, nhóm mặt hàng này có xu hướng tăng cao so với giai đoạn trước, tốc độ tăng trưởng chung giai đoạn 2010-2015 là 9.1\%, giai đoạn 2015-2017 là 12.5\%. Tại Hải Phòng hiện nay, mới chỉ có tổng kho xăng dầu của Công ty CP Cảng Dịch vụ Dầu khí Đình Vũ (PTSC Đình Vũ) đang cung cấp chủ yếu xăng dầu và khí hóa lỏng cho khu vực Hải Phòng và miền Bắc (Bộ giao thông vận tải 2019).

\subsection{8 Ô nhiễm nước biển và xả thải công nghiệp, khu công nghiệp}

Tính toán sơ bộ trên 28 tỉnh thành ven biển nước ta, lượng chất thải rắn sinh hoạt phát sinh (Bảng 19) vào khoảng 14.03 triệu tấn/ năm, tương đương gần 38,500 tấn/ngày (Nguyễn 2012).

Các chất thải từ các khu công nghiệp, việc nuôi trồng thủy hải sản, rác thải sinh hoạt, rác thải y tế,.... làm ảnh hưởng không nhỏ tới hệ sinh thái, tài nguyên biển và ven biển ở nước ta. Nhìn chung, chất lượng nước biển ven bờ Hải Phòng đã có dấu hiệu ô nhiễm cục bộ tại nhiều nơi. Các chất ô nhiễm chủ yếu do dầu, COD, TSS tại các khu vực cảng và cửa sông. Vấn đề ô nhiễm biển lớn nhất của Hải Phòng là do ô nhiễm dầu do các hoạt động vận tải, tàu thuyền, kinh doanh và trữ dầu, tràn dầu... Không những vậy, hầu hết các tàu biển Việt Nam có tuổi trung bình 15 năm nên trang thiết bị phần lớn đều cũ kỹ, lạc hậu, các thiết bị như máy phân ly dầu nước, lọc dầu, báo chỉ số nồng độ thải... để phòng ngừa ô nhiễm môi trường vừa thiếu và vừa không được bổ sung; nhiều phương tiện chưa hề được lắp đặt các thiết bị thu gom chất thải. Mặc dù đã có các quy định về thu gom chất thải từ tàu, việc tuân thủ và kiểm tra vẫn chưa đáp ứng được. Việc xả nước thải, nước la canh, chất thải rắn ra các vùng nước vẫn còn là vấn đề nan giải, đặc biệt là xả các chất thải có dầu, mỡ, gây ô nhiễm biển do dầu (Bảng 20 và Bảng 21).

Đến nay, ở Việt Nam, đã đưa ra rất nhiều các văn bản nghị định, quyết định, chiến lược đề án nhằm kiểm soát tình hình ô nhiễm biển, bảo vệ môi trường biển, an ninh an toàn biển. Việt Nam còn tham gia các công ước quốc tế như Công ước năm 1982 của Liên hiệp quốc về Luật Biển (UNCLOS); Công ước MARPOL 73/78; Công ước quốc tế về trách nhiệm dân sự đối với các tổn thất do ô nhiễm dầu CLC 1969 và 1992 với những quy định nhằm bảo đảm tài chính cho những bên bị thiệt hại do tàu dầu gây ra và giới hạn trách nhiệm dân sự của chủ tàu; Công ước COLREG về các quy tắc quốc tế phòng, tránh đâm, va trên biển năm 1972; Công ước BASEL về kiểm soát vận chuyển xuyên biên giới các chất độc hại và việc loại bỏ chúng năm 1989; Công ước về đa dạng sinh học năm 1992; Công ước RAMSAR về các vùng đất ngập nước có tầm quan trọng quốc tế đặc biệt như là nơi cư trú 
Bảng 19. Nguồn và mức độ chất thải rắn

\begin{tabular}{|c|c|}
\hline Nguồn chất thải & Mức độ phát thải \\
\hline Nuôi tôm & $\begin{array}{l}\text { - Trung bình với mỗi ha nuôi tôm sẽ xả ra môi trường khoảng } 5 \text { tấn chất thải rắn và hàng } \\
\text { chục nghìn m3 nước thải. } \\
\text { - Hiện nay, tổng diện tích nuôi tôm là khoảng trên } 600 \text { nghìn ha, ước tính sẽ thải ra gần } 3 \\
\text { triệu tấn chất thải rắn. }\end{array}$ \\
\hline Công nghiệp & $\begin{array}{l}\text { - Theo số liệu thống kê sơ bộ năm 2009, tổng khối lượng chất thải rắn công nghiệp phát } \\
\text { sinh tại dải ven biển vào khoảng } 2.42 \text { triệu tấn/năm (khoảng 6,600 tấn/ngày tương ứng } \\
\text { với khoảng } 50 \% \text { lượng chất thải rắn công nghiệp phát sinh trên toàn quốc, 13,100 tấn/ } \\
\text { ngày). }\end{array}$ \\
\hline Hàng hải và đóng tàu & • Bụi hạt nix (hay xỉ đồng) là nguyên nhân phát thải chính. \\
\hline Chất thải y tế & $\begin{array}{l}\text { - Đến năm 2009, thống kê cho thấy tổng cộng hơn } 248 \text { tấn/ngày chất thải rắn y tế phát } \\
\text { sinh tại các tỉnh thuộc dải ven biển (tính chung cả bệnh viện đa khoa, trung tâm y tế dự } \\
\text { phòng, trạm xá...), trong đó có 40-50 tấn/ngày (tương ứng với khoảng 20\%) là chất thải } \\
\text { rắn y tế nguy hại phải xử lý }\end{array}$ \\
\hline Sự cố tràn dầu & $\begin{array}{l}\text { - Theo thống kê, số vụ tràn dầu do tai nạn tàu hàng hải trong giai đoạn } 1989 \text { đến } 2009 \text { là } \\
\text { trên } 100 \text { vụ;đổ ra biển từ vài chục đến hàng trăm tấn dầu. } \\
\text { - Ví dụ vào tháng 2/2007, một vụ tràn dấu không rõ nguốn gốc với tổng lượng dầu lên } \\
\text { đến } 1,700 \text { tấn đã ảnh hưởng đến } 20 \text { tỉnh/thành ven biển, chủ yếu là các tînh miền Trung } \\
\text { (từ Hà Tinh trở xuống nam). } \\
\text { - Khoảng } 50 \% \text { lượng dầu gây ô nhiễm biển nước ta là do các tàu thuyền nhỏ dưới } 45 \text { mã } \\
\text { lực với thiết bị máy móc lạc hậu, không được trang bị máy phân ly dầu nước. }\end{array}$ \\
\hline Khai thác dầu khí & $\begin{array}{l}\text { - Cho đến 2012, đã có } 7 \text { vụ rò rỉ dầu xảy ra tại các dàn khoan dầu khí, chưa kể các nước } \\
\text { khác trong khu vực Biển Đông theo báo cáo của Tổng công ty dầu khí Việt Nam. } \\
\text { - Có khoảng } 340 \text { giếng khoan hoạt động thăm dò và khai thác dầu khí ở vùng biển nước } \\
\text { ta. Hoạt động này thải ra một khối lượng lớn nước lẫn dầu và phát sinh khoảng 5,600 } \\
\text { tấn chất thải rắn, trong đó chất thải rắn nguy hại chưa có bãi chứa và nơi xử lý chiếm } \\
\text { 20-30\%. }\end{array}$ \\
\hline
\end{tabular}

Nguồn: Nguyễn 2012

Bảng 20. Tải lượng chất gây ô nhiễm đổ ra biển (Đvt: Nghìn tấn)

\begin{tabular}{lrrrrrrr}
\hline & COD & BOD & N-T & P-T & TSS & HCBVTV & KLN \\
\hline Hải phòng - Quảng Ninh & 206.4 & 39 & 38.8 & 20.7 & 17.24 & 51.5 & 7.8 \\
\hline Bà Rịa - Vũng Tàu - TP.HCM & 175.6 & 38.9 & 125.9 & 23.3 & 384.2 & 3 \\
\hline
\end{tabular}

Nguồn: Nguyễn 2012

của các loài chim nước năm 1971, sửa đổi theo Nghị định thư Paris năm 1982. Mặc dù vậy, quy phạm pháp luật về phòng ngừa, xử lý và khắc phục ô nhiễm môi trường biển chủ yếu mới chỉ được ban hành dưới dạng các văn bản dưới luật (các thông tư, quy chế do các bộ, ngành ban hành) mà chưa được xây dựng thành một đạo luật (Cục Hàng hải Việt Nam 2013). Những ảnh hưởng từ hoạt động vận tải tàu thuyền đến môi trường biển, hệ sinh thái dưới biển và ven biển là rất lớn, trong đó có rừng ngập mặn. Không những vậy, rừng ngập mặn có vai trò quan trọng đối với việc giảm ô nhiễm từ khí thải, ngăn chặn dầu thừa, rác thải từ biển vào khu dân cư, nuôi trồng thủy sản, vì vậy cần có cơ chế chi trả dịch vụ môi trường rừng đối với ngành logistics, đặc biệt là các tàu vận tải trên biển.

\subsection{9 Ô nhiễm nuôi trồng thủy hải sản}

Tại Hải Phòng, nuôi trồng thủy hải sản là nguồn thu chính của nhiều gia đình, cộng đồng và địa phương. Kinh tế thủy sản phát triển mạnh trên cả hai lĩnh vực nuôi trồng và khai thác. Nuôi trồng thủy sản phát triển theo hướng thâm canh và bán thâm canh hiệu quả kinh tế cao; tăng cường năng lực khai thác thủy sản xa bờ (Trần 2018). Hải phòng cũng có khả năng chế biến thuỷ sản lớn nhất cả nước khi mà số cơ sở sản xuất chế biến thuỷ sản chiếm tới $75 \%$ 
Bảng 21. Nồng độ các chất ô nhiễm trong nước vượt quá mức quy định đối với mục đích bảo tồn, mục đích nuôi trồng thủy sản và mục đích khác của các khu vực ven biển và cảng cá Cát Bà thuộc Hải Phòng từ 2005-2011

Đvt: lần

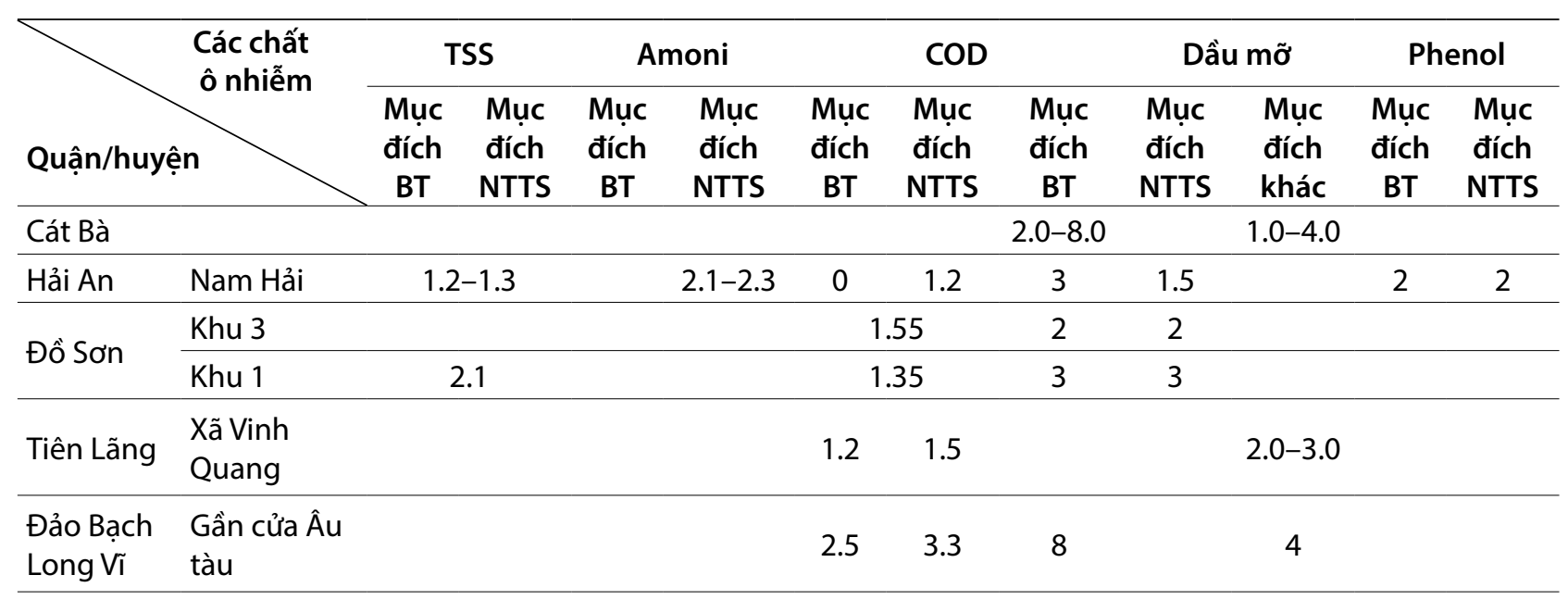

Nguồn: Cục Điều tra và Kiểm soát tài nguyên Môi trường biển 2013

số lượng trong vùng kinh tế trọng điểm Bắc bộ và số kho lạnh chiếm tới $50 \%$ sức chứa của các cơ sở chế biến thuỷ sản tại miền Bắc. Bên cạnh đó, cơ sở dịch vụ hậu cần thủy sản được củng cố và mở rộng; các khu neo đậu tránh trú bão có tổ chức và được xây dựng với trang thiết bị ngày càng hiện đại (Trần 2018). Năm 2016, GRDP lĩnh vực thủy sản trên địa bàn thành phố đạt 2,687.8 tỷ đồng, chiến $2.034 \%$ GRDP toàn thành phố và chiếm $30.8 \%$ tổng GRDP nhóm ngành nông, lâm, thủy sản; tăng 1.34 lần so với năm 2006. Kim ngạch xuất khẩu thủy sản đạt 50.83 triệu USD. Một số quốc gia và vùng lãnh thổ trên thế giới bao gồm Nhật Bản, Hàn Quốc, Hồng Kông, Trung Quốc, EU, ASEAN,... đã nhập khẩu các sản phẩm thuỷ sản của thành phố Hải Phòng. Tốc độ tăng trưởng giá trị sản xuất thủy sản bình quân giai đoạn 2011-2015 gấp hơn 2 lần tốc độ tăng trưởng chung toàn ngành đạt, 7.07\%/năm, trong đó: Giá trị khai thác thủy sản tăng 6.55\%/năm, giá trị nuôi trồng và dịch vụ tăng $7.48 \% /$ năm, góp phần quan trọng vào chiến lược phát triển kinh tế biển và bảo vệ an ninh quốc phòng biển đảo của thành phố (Trần và Đỗ 2018).

Tuy nhiên, nuôi trồng thủy sản cũng dẫn đến ô nhiễm môi trường nghiêm trọng do (i) lượng thức ăn của các loài nhuyễn thể còn thừa lắng xuống; (ii) mật độ nuôi dày đặc làm hạn chế tốc độ của dòng chảy giảm khả năng trao đổi nước sạch gây ứ đọng các chất thải và tăng nguy cơ dịch bệnh đối với các loại thủy hải sản; (iii) việc chở cát từ nơi khác về phục vụ nuôi hải sản đã làm thay đổi môi trường tự nhiên đáy vịnh, xuất hiện nhiều loại vi tảo gây bệnh, ảnh hưởng nguồn lợi thủy sản tự nhiên như tu hài, hàu,... Hiện tượng thủy triều đỏ và dịch bệnh hải sản liên tiếp xuất hiện ở một số khu vực như Hang Vẹm, Vụng O,... gây thiệt hại lớn đến kinh tế các hộ nuôii; (iv) rác thải sinh hoạt (gần 1,300 người); rác thải thu gom từ ô lồng bè tới $10 \mathrm{~m}^{3} / \mathrm{ngày}$ chưa kể lượng rác trôi dạt trên vịnh (Trần và Vũ 2018). Cán bộ Chi cục Thủy sản Hải Phòng cũng cho biết lông bè hoạt động ở khu vực du lịch ảnh hưởng đến môi trường, đặc biệt là nguồn nước, như rác thải, thức ăn. Các hộ thường làm lồng bè không có quy chuẩn và không đảm bảo vệ sinh, thường xả thải ngay xuống biển.

Theo thống kê của Ban quản lý các vịnh tại Cát Bà hiện có tổng 441 cơ sở nuôi trồng thủy sản, 9,507 ô nuôi thủy hải sản, trong đó có 1,598 ô nhà ở, khoảng 16,000 quả phao xốp, số lượng bè, giàn bè nuôi thủy sản trên địa bàn huyện Cát Hải đã vượt quá số quy hoạch là 292 bè/5,241 ô lồng (Bảng 22, Tài nguyên và Môi trường 2018b). Nên vị trí neo đậu phần lớn tự phát, chưa tuân thủ theo đúng quy định kỹ thuật, bảo vệ môi trường và quan trọng là chưa được cấp có thẩm quyền cấp phép đã trực tiếp làm ảnh hưởng đến môi trường sinh thái tự nhiên các vịnh thuộc quần đảo Cát Bà (Tài 
Bảng 22. Số lượng cơ sở nuôi trồng thuỷ sản tại Hải Phòng

\begin{tabular}{lcl}
\hline Ngành & Số lượng & Nguồn \\
\hline $\begin{array}{l}\text { Cơ sở nuôi trồng } \\
\text { thuỷ sản }\end{array}$ & 441 & $\begin{array}{l}\text { Tài nguyên và Môi } \\
\text { trường 2018b }\end{array}$ \\
\hline $\begin{array}{l}\text { Giàn nuôi nhuyễn } \\
\text { thể }\end{array}$ & 525 & $\begin{array}{l}\text { Tài nguyên và Môi } \\
\text { trường 2018b }\end{array}$ \\
\hline $\begin{array}{l}\text { Ô nuôi thủy hải sản } \\
\text { Tài nguyên và Môi } \\
\text { trường 2018b }\end{array}$ \\
\hline
\end{tabular}

nguyên và Môi trường 2018b). Ngoài ra, còn các cơ sở kinh doanh dịch vụ xăng dầu trên vịnh, những nơi nuôi thả cá đã đổ một lượng không nhỏ thức ăn chưa phân hủy hết của cá ra môi trường, các thùng phao xốp chịu tác động, sự va đập sóng gió sẽ bị rã và gây ô nhiễm mặt nước. Bên cạnh đó, còn tồn tại 525 giàn nuôi nhuyễn thể. Tất cả tạo thành chất thải rắn tại các bãi triều rạn ngầm, làm hỏng và mất đi môi trường sống của các sinh vật sống ở tầng đáy như san hô, rong rêu. Theo Chi cục Thủy sản Hải Phòng, theo quy hoạch năm 2020, thành phố sẽ hủy bỏ hết toàn bộ số lượng giàn bè trên địa bàn Cát Hải, Cát Bà, nhằm mục đích phát triển du lịch và quy hoạch nuôi trồng thủy hải sản thâm canh, áp dụng công nghệ cao tập trung khu Dương Kinh, Hải Phòng.

\subsubsection{0 Ô nhiễm từ thuyền du lịch - Cảng tàu du lịch (tàu cỡ nhỏ)}

Theo Điều 13, Quy định về cảng, bến khách du lịch- Quyết định số 32/2018/QĐ-UBND về ban hành quy chế quản lý hoạt động du lịch trên các vịnh thuộc quần đảo Cát Bà, huyện Cát Hải, thành phố Hải Phòng (Ủy ban nhân dân thành phố Hải Phòng 2018), cảng, bến khách du lịch, bao gồm: cảng, bến trong đất liền; cảng, bến tại điểm tham quan; và khu vực neo đậu tàu thủy lưu trú du lịch.

Các hoạt động khai thác du lịch của Hải Phòng diễn ra chủ yếu ở khu vực ven biển như bãi tắm Đồ Sơn và đảo Cát Bà. Có các tuyến tàu cánh ngầm cao tốc khai thác du lịch từ đất liền sang đảo Cát Bà như Bến Bính - Bến Cái Viềng, Bến Bính - Bến Cát Bà. Ngoài ra tại đảo Cát Bà có bến Gia Luân tiếp nhân các tàu, phà du lich từ Quảng Ninh. Ông Vũ Huy Thưởng - Phó Giám đốc Sở Du lich Hải Phòng cho biết:Trên đia bàn thành phố hiện có 123 tàu du lịch, trong đó Cát Bà có 111 tàu, Đồ Sơn có 12 tàu (Hiệp 2018).
Trên thực tế, dù hình thành đã lâu nhưng mẫu mã, chất lượng các tàu tuyến từ trung tâm đảo Cát Bà đi đến các đảo nhỏ vẫn còn nhiều hạn chế, tiềm ẩn không ít nguy cơ mất an toàn. Các đơn vị kinh doanh loại hình này chủ yếu là hộ gia đình và doanh nghiệp nhỏ, sở hữu ít phương tiện, mức độ đầu tư cũng hạn chế, đa số đều là tàu vỏ gỗ được hoán cải từ tàu đánh bắt hải sản (Hiệp 2018). Tuổi tho của nhiều tàu đã hơn 10 năm, với kiểu dáng và kích cỡ đa dang. Trên các tàu đều có trang bi áo phao, bình chữa cháy, nhưng chất lượng của những thiết bị này ở mỗi tàu mỗi khác. Rất ít tàu có trang thiết bị sơ cấp cứu đúng tiêu chuẩn. Thậm chí, 63/111 tàu du lịch ở Cát bà đã bị tạm đình chỉ hoạt động vào 29/5/2018, trong đó có 27 tàu chở khách tham quan vịnh và 36 tàu lưu trú nghỉ đêm trên vịnh, do chưa đủ điều kiện cũng như thiếu chứng chỉ phòng cháy chữa cháy và nghiệp vụ du lịch (Hiệp 2018).

Hiện chưa có con số cụ thể về lượng chất thải gây nguy hại tới môi trường từ những tàu du lịch này tại Hải Phòng. Tuy nhiên, ở Vịnh Hạ Long, theo điều tra từ Tổ chức bảo tồn thiên nhiên quốc tế (IUCN), hiện chưa đến $10 \%$ tàu du lịch có hệ thống xử lý nước thải đen, $90 \%$ còn lại là tàu kiểu cũ không thể lắp đặt hệ thống xử lý nước thải. Theo ông Nguyễn Duy Phú, Chủ tịch Hội đồng quản trị Du thuyền Pelican, khó khăn này rất khó để khắc phục được, chỉ có cách chờ các tàu cũ hết niên hạn và đổi tàu mới. Lượng nước la canh để làm mát máy và động cơ của mỗi tàu du lịch trung bình là $1.05 \mathrm{~m}^{3}$ mỗi chuyến đi. Theo thông tin từ các thuyền trưởng tàu du lịch được khảo sát trong nghiên cứu của IUCN năm 2015, 75\% số tàu du lịch đã tách dầu ra khỏi nước trước khi xả nước ra Vịnh; 19\% mang nước la canh vào bờ để xử lý sau mỗi chuyến đi và $3 \%$ số tàu du lịch xả thẳng nước la canh ra Vịnh mà không có bất kì biện pháp xử lý nào (Lê 2015). Như vậy, ở Hải Phòng, với số lượng lớn tàu thuyền du lịch cỡ nhỏ không có có hệ thống tách dầu khỏi nước trước khi xả, lượng nước thải chủ yếu sẽ được xả thẳng ra biển.

Trung bình trong mỗi chuyến đi, một khách du lịch tạo ra khoảng $0.5 \mathrm{~kg}$ chất thải rắn (rác) và 100 lít nước thải (Lê 2015). Với mỗi thuyền, lượng rác và chất thải thực phẩm thải ra khoảng 50-100 kg mỗi ngày (JICA 2013). Tuy nhiên, các trang thiết bị cần thiết để thu gom và xử lý chất thải lỏng không được trang bị trên 
nhiều tàu. Các chất thải rắn đôi khi được xả trực tiếp ra biển như vỏ hải sản, trái cây hư hỏng, rau quả và thậm chí cả ống tiêm. Một nguyên nhân dẫn tới sự ô nhiểm trên bề mặt nước đó là ô nhiễm dầu từ các động cơ tàu.

\subsubsection{Công ty cung cấp nước sạch}

Việc thu phí dịch vụ môi trường rừng đối với các cơ sở sản xuất và cung ứng nước sạch mà sử dụng dịch vụ điều tiết và duy trì nguồn dự trữ nước của rừng đã được quy định tại Nghị định 99 của Chính Phủ Việt Nam năm 2010. Theo đó, các công ty này cần phải trả mức phí 40 đồng $/ \mathrm{m}^{3}$ nước thương phẩm, hay khối lượng nước bán cho người tiêu dùng. Đến năm 2016, khi nghị định 147 được ban hành nhằm sửa đổi và bổ sung nghị định 99, mức phí này đã được điều chỉnh tăng lên 52 đông $/ \mathrm{m}^{3}$ nước thương phẩm.

Chương trình PFES đã được đưa vào áp dụng từ năm 2017 tại Hải Phòng. Tuy Quỹ Bảo vệ và Phát triển Rừng Hải Phòng vẫn chưa có hệ thống và tài khoản ngân hàng rõ ràng cho việc quản lý và giám sát dòng tiền chi trả, các công ty cung cấp nước vẫn khẳng định sự mong muốn chi trả dịch vụ môi trường rừng. Cho đến năm 2019, những công ty này vẫn thể hiện sự sẵn sàng và tình nguyện tham gia chi trả. Hiện tại, ngân hàng Nông nghiệp và Phát triển Nông thôn Hải Phòng đã thành lập một tài khoản ngân hàng tạm thời để tiếp nhận các khoản tiền này, tuy rằng theo nguyên tắc, khoản tiền nên được nộp về Quỹ Bảo vệ và Phát triển Hải Phòng. Theo báo cáo của Sở Nông nghiệp và Phát triển Nông thôn thành phố Hải Phòng về công tác quản lý bảo vệ rừng ven biển và thực hiện chính sách chi trả dịch vụ rừng, đến tháng $02 / 2019$, tổng nguồn thu quỹ dịch vụ môi trường là 13.16 tỉ đồng. Trong đó, Nhà máy cấp nước Hải Phòng là công ty nước duy nhất trả phí dịch vụ môi trường rừng, nhưng mức chi trả chiếm đến 55.5\% (7.31 tỉ đồng) (Sở Nông nghiệp và Phát triển Nông thôn Hải Phòng 2019).

Nhà máy nước Hải Phòng, hiện nay là công ty nước Hải Phòng, bao gồm Nhà máy nước Uông Bí và Trung tâm cấp nước tại 54 Đinh Tiên Hoàng, Hải Phòng. Từ ngày 10/8/2006 và Quyết định số 2759/QĐ-UBND, nhà máy nước Hải Phòng chuyển thành Công ty TNHH một thành viên Cấp nước Hải Phòng hoạt động trong lĩnh vực kinh doanh sản phẩm công ích. Hệ thống cấp nước Hải Phòng bao gồm: 8 nhà máy với tổng công suất $213,500 \mathrm{~m}^{3} / \mathrm{ngày}$, hơn $300 \mathrm{~km}$ đường ống truyền dẫn chính và hàng nghìn $\mathrm{km}$ đường ống phân phối, phục vụ cho 265,000 khách hàng với dịch vụ cấp nước ổn định đảm bảo bảo chất lượng. Số dân được dùng nước sạch từ hệ thống cấp nước của thành phố hiện nay khoảng 1.2 triệu người.

Theo Quy hoạch tài nguyên nước thành phố Hải Phòng đến năm 2020, tầm nhìn đến năm 2030, các nguồn ô nhiễm nước cần phải được bảo vệ đến từ nhiều nguồn và ngành nghề (Bảng 23):

Để đánh giá khả năng chi trả của các đơn vị cung cấp và khai thác nước, trước hết cần xem xét đơn vị đó đã tham gia chi trả PFES/PES hay có nhận thức như thế nào vể PFES, nguồn nước công ty đang khai thác (ví dụ như nước ngầm, nước sông), công suất khai thác và thực tiễn cung ứng nước, doanh thu hoặc chi phí hoạt động hằng năm. Vai trò của cả rừng trên cạn và rừng ngập mặn trong mục tiêu phát triển an sinh xã hội này cần được xem xét và thử nghiệm.

Bảng 23. Quy hoạch tài nguyên nước thành phố Hải Phòng đến năm 2020

\begin{tabular}{ll}
\hline Địa điểm & Nguồn nước cần được bảo vệ \\
\hline Sông Rế & Khu vực lấy nước của các Nhà máy nước An Dương, Vật Cách, Kim Sơn, Quán Vĩnh. \\
\hline Sông Giá & • Các công ty xi măng Chinfon, xi măng Hải Phòng, \\
& • Công nghiệp tàu thủy Nam Triệu, Công nghiệp tàu thủy Phà Rừng, \\
& • Cổ phẩn Nhiệt điện Hải Phòng, \\
& • Khu công nghiệp VSIP và \\
& • Các nhà máy nước sạch mini ven sông \\
\hline Sông Đa Độ & Nhà máy nước Cầu Nguyệt, Nhà máy nước Đồ Sơn, Nhà máy nước Hưng Đạo, Nhà máy nước \\
\hline
\end{tabular}




\subsection{Dịch vụ cung ứng bãi đẻ}

Liên Hợp Quốc ước tính rằng các loài có liên quan đến rừng ngập mặn chiếm tới $30 \%$ sản lượng thuỷ sản và gần như $100 \%$ sản lượng tôm ở các vùng biển của các quốc gia trên thế giới. Khoảng 50\% sản lượng tôm sú được nuôi và khai thác thu được của ngành thuỷ sản có liên quan đến rừng ngập mặn. Đối với người nghèo, nguồn thu nhập chính đến từ việc thu nhặt cua, ốc, cá, tôm từ rừng ngập mặn. Ví dụ, cua biển có mối quan hệ mật thiết với rừng ngập mặn cũng là một loại hải sản có giá trị kinh tế cao. Trong khoảng thời gian từ tháng 8 đến tháng 11 hàng năm, ấu trùng cua biển sẽ từ biển vào rừng ngập mặn để sinh trưởng và phát triển (MARD 2010). Việc mất rừng ngập mặn làm giảm đáng kể thức ăn cho các loài thuỷ sản như là sinh vật phù du và sinh vật đáy, dẫn đến tình trạng tôm nuôi theo hình thức quảng canh giảm năng suất: năm 1980 là 200-250 kg/ha/vụ, đến năm 2001 chỉ còn 70-80 kg/ha/vụ. Theo ước tính, trước đây có thể khai thác được từ 700-1,000 $\mathrm{kg}$ thuỷ sản trên 1 ha RNM, nhưng hiện nay chỉ thu được 5\% so với trước đây (MARD 2010). Tái tạo nguồn lợi thuỷ sản còn giúp cho cuộc sống của cộng đồng ngư dân làm nghề khai thác có nhiều cơ hội để nâng cao cuộc sống (MARD 2010).

Ngoài ra, việc ngày càng tăng mật độ nuôi thủy hải sản dày đặc tại các lồng bè cũng gây ra ô nhiễm môi trường không hề nhỏ, đặc biệt tại các vùng vịnh Lan Hạ, Cái Bè. Với lợi thế về phát triển kinh tế du lịch, dịch vụ và nguồn nước sạch tự nhiên, đảo Cát Bà đã được Viện Nghiên cứu Nuôi trông Thủy sản 1 (Bộ NN-PTNT) chọn để phát triển Trung tâm Quốc gia Giống thủy hải sản Miền Bắc. Tuy nhiên, do nguồn nước ngày càng xuống cấp, trung tâm đã phải di rời ra ngoài xa Vịnh Lan Hạ.

Hải Phòng không sở hữu diện tích nuôi trồng hải sản lớn như vùng sông Mê Kông. Nuôi trồng thủy và hải sản tập trung tại xã Phú Long và các khu vực lân cận và thuộc vườn Quốc gia Cát Bà. Ở xã Phú Long, nhiều đơn vị nuôi trồng hải sản đang tham gia hoạt động tạo kim ngạch xuất khẩu. Phỏng vấn với đơn vị nuôi trồng hải sản tại xã cho thấy rằng họ có sự sẵn lòng thấp trong việc cung cấp các hỗ trợ và nỗ lực để bảo vệ và trồng lại rừng ngập mặn vì các lý do sau:

- Trong hầu hết các ao nuôi của họ, cây ngập mặn chiếm hơn 60\% tổng diện tích. Một đơn vị được phỏng vấn cho biết: “Nếu chúng tôi cắt giảm vùng cây ngập mặn, chúng tôi sẽ có nhiều diện tích hơn để nuôi trồng hải sản, nên chỉ có một số ít người là có hứng thú với chúng thôi. "Tuy nhiên, một người được phỏng vấn khác lại cho thấy rằng: "Chúng tôi cần có cây ngập mặn trong ao nuôi của chúng tôi. Chúng tôi có hai ao, một ao với $50 \%$ diện tích là cây ngập mặn và ao còn lại không có. Ao nuôi có cây ngập mặn có sản lượng cao hơn và tỉ lệ sống của cá tốt hơn."

- Cho dù người ở ngoài địa phương hay người thuộc địa phương muốn mở rộng diện tích rừng ngập mặn bằng cách trồng mới thêm thì cũng không còn quỹ đất để làm được điều này. Hầu hết các vùng đất phù hợp để bảo vệ rừng ngập mặn hiện nay đều được chuyển giao cho các công ty tư nhân, đơn vị quân sự và người dân địa phương nhằm phát triển hạ tầng.

- Luật lệ bất hợp lý: họ không thể đắp đê và đốn hạ rừng ngập mặn.

- Hao tốn tiền của và thiếu tính bền vững. Một vài người được phỏng vấn chỉ ra rằng những nỗ lực của họ cho việc bảo vệ và trông lại rừng ngập mặn là không bền vững và tốn thời gian và ngân sách của họ. Một người được phỏng vấn nói rằng: "Chúng tôi chỉ vừa trồng một vùng bảo vệ ngập mặn và hai tuần sau đó, bên quân đội đã đổ cát vào khu vực này và chuyển đổi thành đường giao thông và công trình. Tương tự, một héc-ta rừng ngập mặn được trồng với hổ trợ từ một tổ chức phi chính phủ địa phương bây giờ cũng đã thuộc về một tập đoàn lớn của Viêt Nam. Vậy thì tại sao chúng tôi cần phải trả tiền cho nỗ lực để bảo vệ rừng ngập mặn khi không ai tôn trọng rừng của chúng tôi?"

\subsection{Dịch vụ vẻ đẹp cảnh quan và các dịch vụ liên quan.}

Hải Phòng và Cát Bà là địa điểm thu hút được khách du lịch cả trong và ngoài nước. Du lịch cũng đóng góp một phần quan trọng trong phát triển kinh tế xã hội và đảm bảo đời sống cho người dân. Giai đoạn 2006-2016, Hải Phòng đón lượng khách du lịch tăng bình quân 9.9\%/năm, trong đó khách quốc tế tăng 3.3\%/ năm; năm 2017 Hải Phòng đón 6.7 triệu khách du lịch (Cổng tin tức thành phố Hải Phòng 2019) (Bảng 36). Doanh thu du lịch biển chiếm hơn $48 \%$ doanh thu của toàn ngành du lịch. 
Nhiều dự án đầu tư phát triển đã được triển khai như: Khu du lịch quốc tế Hòn Dấu, Khu nghỉ dưỡng FLC Cát Bà với sự tham gia đầu tư của các tập đoàn FLC, SunGroup... (Trần và Đỗ 2018).

Có rất nhiều công ty du lịch ở Hà Nội và Hải Phòng phải trả phí bảo vệ môi trường, tuy nhiên những khoản phí đó cho tới nay chưa hể được đóng góp để bảo vệ môi trường rừng ngập mặn. Nhiều dịch vụ du lịch đi kèm như thuyền bè du lịch ảnh hưởng nghiêm trọng tới sinh thái biển và rừng ngập mặn nhưng cũng chưa góp phần chi trả dịch vụ môi trường rừng ngập mặn. Chính quyền Hải Phòng đã nộp đơn xin Khu vực Cát Bà trở thành Khu dự trữ sinh quyển của Liên hợp quốc, theo chương trình Con người và Sinh quyển của UNESCO. Tuy nhiên, các hướng dẫn của Khu dự trữ sinh quyển của Liên Hợp Quốc yêu cầu rõ ràng các hoạt động thúc đẩy kinh tế của con người phải thân thiện tới môi trường. Các hoạt động kinh tế như vậy được coi là "bền vững," nghĩa là chúng không được gây thiệt hại không thể khắc phục cho hệ sinh thái. Trong khi đó, Khu dự trữ sinh quyển của Việt Nam lại phụ thuộc rất nhiều vào du lịch, chính xác là ngành du lịch "bong bóng" của Cát Bà đang đe dọa môi trường địa phương. Số lượng du khách đã tăng lên 10 lần kể từ giữa những năm 90.

Do đảo Cát Bà tiếp nhận một số lượng lớn khách du lịch hàng năm, 3 giải pháp có thể thu phí chi trả dịch vụ môi trường rừng cho rừng ngập mặn bao gồm:

- Với công ty tập đoàn du lịch: thu 1-2\% doanh thu như đã quy định trong Nghi định 99.

- Thu phí thông qua vé phà tới Cát Bà, dù chỉ áp dụng cho người dân ngoại tỉnh, Hải Phòng vẫn có thể thu được một khoản tài chính đủ lớn. Phương pháp rất khả thi vì vé đã được bán ở hai đầu cảng. Cũng có thể thu phí tương tự như vậy nhưng với giá thấp hơn ở Đồ Sơn.

- Thu phí vào cửa của Vườn Quốc Gia. Với múc phí hiện nay chỉ có 2 USD/người (khoảng 50,000VND/người) không đủ để trang trải cho chi phí vận hành của Vườn Quốc Gia. Phải tăng lên mức từ 15-20 USD (350,000470,000VND) mới có thể đảm bảo VQG tự vận hành hiệu quả. Phí này nên áp dụng cho vé vào cửa của Vườn quốc gia và các tàu từ cảng Cát Bà.
- Có thể thu phí cao hơn cho khách nước ngoài do phù hợp với mức thu nhập và khoản chi tiêu du lịch của họ.

- Phí du lịch có thể áp dụng trên quy mô toàn tỉnh, hoặc chỉ áp dụng tại các khu nghỉ dưỡng trong địa bàn du lịch. Tuy nhiên, thu phí từ các khách sạn và khu nghỉ dưỡng sẽ khá phức tạp và có chi phí giao dịch cao. Thu phí từ tàu, phà và vé vào cửa sẽ dễ dàng và khả thi hơn là thu qua khách sạn.

- Tổ chức các tour du lịch sinh thái: các tour sinh thái có thể được gắn nhãn là Eco-tour, cũng giống như gắn nhãn FSC dành cho các sản phẩm từ gỗ. Họ có thể thu tiền cao hơn các tour khác nhờ uy tín này (Boris van Zanten và cộng sự 2018).

\subsection{Dịch vụ cung cấp nguyên liệu thực phẩm}

Tại Hải Phòng, một số doanh nghiệp địa phương hiện đang phát triển một số sản phẩm rượu vang và nước giải khát với nguồn nguyên liệu thu được trực tiếp từ rừng ngập mặn. Quy mô của nhứng công ty này chủ yếu là vừa và nhỏ. Nguồn nguyên liệu sản xuất là quả bần chua được cho là dư thừa khi công ty không cần đầu tư, chỉ cần thu mua lại từ người dân địa phương. Theo quan điểm của công ty, việc sử dụng quả bần chua là một phương pháp tận dụng tài nguyên sẵn có, không cần đầu tư và để góp phần vào việc bảo vệ hệ sinh thái rừng ngập mặn vì khi quả bần rơi xuống nước sẽ sản sinh độc tố ảnh hưởng đến hệ sinh thái cũng như các sinh vật dưới tán rừng ngập mặn. Ngoài ra, khi công ty có nhu cầu, người dân địa phương sẽ thu hái quả bần thông qua hợp tác xã để bán lại cho công ty và có thêm thu nhập trung bình 200,000/ngày công/người, giúp nâng cao ý thức bảo vệ rừng ngập mặn của người dân địa phương khi họ có thể có được lợi ích thực tế từ rừng ngập mặn. Tuy nhiên, những diện tích rừng ngập mặn là kết quả của các dự án trước đó như dự án chữ thập đỏ trồng rừng ngập mặn để chống biển đổi khí hậu ở xã Vinh Quanh, huyện Tiên Lãng, trải dài ở khu vực Kiến Thụy và Đồ Sơn.

Sản lượng trung bình của một cây to có thể cho ra 50-100kg quả; công suất hoạt động của nhà máy được cho là dư thừa tại thời điểm này vì đầu ra chưa lớn. Dù hiệu quả kinh tế từ các sản phẩm với nguyên liệu từ rừng ngập mặn 
được các công ty đánh giá là có hiệu quả hơn nhiều các mặt hàng khác, họ vẫn còn đang gặp một số khó khăn trong việc phát triển sản xuất. Doanh nghiệp gặp nhiều khó khăn với các cơ chế của nhà nước trong việc đăng ký dựán, đề tài quốc gia, thị phần, thương hiệu, sự cạnh tranh lớn đến từ các doanh nghiệp sản xuất công nghiệp quy mô lớn. Hiện nay, thị phần của công ty chủ yếu ở miền Bắc, trong khi công ty đang muốn mở rộng thị trường cũng như hướng đến xuất khẩu. Bên cạnh đó, công ty cũng sử dụng một số sản phẩm khác từ rừng ngập mặn như thân cây để làm nút và rễ dùng để làm thuốc, tuy nhiên chỉ thực hiện ở mức độ nghiên cứu thay vì sản xuất đại trà.

Hiện nay, tất cả các dịch vụ và nguồn thu từ cây bần mà công ty này hưởng lợi đều từ do diện tích rừng và dịch vụ rừng mà nhà nước trả tiền trồng và bảo vệ. Nói một cách khác, các dịch vụ môi trường đang được hưởng lợi miễn phí từ giới tư nhân mà không phải chi trả gì. Các doanh nghiệp đang làm giàu từ tài nguyên rừng ngập mặn này đều cần phải chi trả dịch vụ môi trường rừng. 


\section{Thảo luận và Đề xuất}

\subsection{Thuận lợi và tiềm năng xây dựng cơ chế PF́ES cho rừng ngập mặn ở Hải Phòng}

Kết quả nghiên cứu tiền khả thi đã cho thấy tiềm năng và tính khả thi của việc xây dựng cơ chế PFES cho rừng ngập mặn tại Hải Phòng bởi:

- Có nhiều dịch vụ tiềm năng mà rừng ngặp mặn có thể đem lại cho các bên có liên quan.

- Có nhiều người mua tiềm năng cho các loại dịch vụ này và một số dịch vụ đã có người mua trong thực tế chứ không còn là lí thuyết (ví dụ: dịch vụ mua bán các-bon với ngân hàng Standard Chartered, công ty năng lượng Stadtwerke Münster ).

- Có nhiều nhóm người mua cùng có nhu cầu với nhiều loại dịch vụ.

- Hải Phòng là thành phố đặt ra những cam kết chính trị về việc thực hiện phát triển kinh tế đi đôi với bảo vệ môi trường nên đã có sẵn nền tảng cam kết chính trị cao.

\subsection{Tính khả thi của các dịch vụ và cơ chế PFES cho từng dịch vụ}

USAID (Sommerville 2016) đã đánh giá tính khả thi của các loại hình dịch vụ và người mua tiềm năng của dịch vụ môi trường rừng tại Việt Nam, trong đó có thành phố Hải Phòng (Bảng 25).

Tuy nhiên, kết quả nghiên cứu tiền khả thi của chúng tôi cho thấy cần có nghiên cứu đầy đủ, chính xác và khoa học hơn cho từng loại dịch vụ đã được xác định là có tiềm năng ở Mục 3 và ở Bảng trên, cụ thể là:

- Cần phải tiến hành nghiên cứu khoa học minh chứng lợi ích về dịch vụ môi trường mà rừng ngập mặn đem lại.

- Nghiên cứu mức sẵn lòng chi trả của các người mua tiềm năng.

- Nghiên cứu cơ chế thu và chi.
- Nghiên cứu cơ chế giám sát và đánh giá để theo dõi và đánh giá tác động của từng cơ chế PFES rừng ngập mặn với từng loại dịch vụ khác nhau.

Với tiềm lực ngân sách có hạn và thời gian hạn chế của dự án SWAMP, trong tất cả các dịch vụ môi trường tiềm năng ở phần $3, \mathrm{CIFOR}$ chọn 2 dịch vụ môi trường là dịch vụ nước sạch và lọc kim loại nặng và dịch vụ chi trả các-bon để tiến hành các nghiên cứu sâu hơn bởi các lí do sau:

- Các phân tích phía trên cho thấy hai dịch vụ này có số lượng người mua tiềm năng lớn nhất.

- Việc thu tiền PFES cho rừng ngập mặn đối với các bên sử dụng dịch vụ như cảng hoàn toàn có thể dựa trên vào hệ thống thu phí tại cảng nên tính khả thi cao hơn so với các dịch vụ khác.

- Cơ chế chi trả các-bon đang được thí điểm tại Việt Nam dưới Nghị định 156 và việc mở rộng cơ chế này đối với rừng ngập mặn sẽ có những đóng góp tích cực cho việc hoàn thiện chính sách PFES cho các-bon. Hơn nữa, thị trường các-bon và mối quan tâm với tín chỉ các-bon đã được hình thành từ lâu nên người mua tiềm năng đã có nền tảng kiến thức và quan tâm rõ ràng.

- Hai dịch vụ môi trường này không chỉ có thể áp dụng đối với rừng ngập mặn mà còn có thể áp dụng được với cả rừng trên cạn nên sẽ có thể tạo hiệu ứng nhân rộng tích cực cho PFES.

Với ngân sách và thời gian hạn chế, CIFOR chỉ có thể tiến hành nghiên cứu với hai loại dịch vụ này. Kết quả rà soát các người mua tiềm năng và dịch vụ có thể thực hiện ở Hải Phòng hi vọng sẽ được sử dụng làm đầu vào cho nhiều dự án khác trong tương lai.

Riêng trong bối cảnh tại Hải Phòng, báo cáo số 2 tiếp theo dự án sẽ tập trung vào việc đưa ra 
Bảng 24. Tổng hợp số lượng các công ty, doang nghiệp hoạt động trên các lĩnh vực tại Hải Phòng

\begin{tabular}{|c|c|c|}
\hline Ngành & Số lượng công ty, doanh nghiệp & Nguồn \\
\hline Cảng, bến cảng & 49 & Bộ giao thông vận tải 2019 \\
\hline Cảng biển & 45 & Thủ tướng Chính phủ 2014 \\
\hline Cảng vận chuyển than & 9 & Tổng công ty tư vấn và thiết kế GTVT - CTCP 2015 \\
\hline Cảng cá, bến cá & 13 & Tài nguyên và Môi trường 2018a \\
\hline Cơ sở nuôi trồng thuỷ sản & 441 & Báo tài nguyên và môi trường 2018 \\
\hline Giàn nuôi nhuyễn thể & 525 & Báo tài nguyên và môi trường 2018 \\
\hline Ô nuôi thủy hải sản & 9,507 & Báo tài nguyên và môi trường 2018 \\
\hline Tàu biển & 600 & Trần và Đỗ 2018 \\
\hline Đóng tàu & 172 & Trần và Đỗ 2018 \\
\hline Dự án khu công nghiệp & 16 & Trần và Đỗ 2018 \\
\hline Tàu du lịch & 123 & Hiệp 2018 \\
\hline Khai thác khoáng sản & 46 & Cơ sở dữ liệu Thông tin doanh nghiệp 2020 \\
\hline Sản xuất gang thép & 50 & Thông tin Công ty tại Hải Phòng 2020 \\
\hline Nhiệt điện & 1 & Cục điều tiết điện lực 2017 \\
\hline Nước sạch & 1 & $\begin{array}{l}\text { Sở Nông nghiệp và Phát triển nông thôn Hải } \\
\text { Phòng } 2019\end{array}$ \\
\hline Trung tâm logistics & 4 & $\begin{array}{l}\text { Quyết định 821/QĐ-TTg của Thủ tướng Chính phủ } \\
\text { ngày } 06 \text { tháng } 07 \text { năm } 2018\end{array}$ \\
\hline Trung tâm logistic nhỏ & 20 & Mai 2019 \\
\hline Hàng không & 1 & Cảng hàng không Quốc tế Cát Bi 2020 \\
\hline Khách du lịch & 6,7 triệu khách & $\begin{array}{l}\text { Cổng tin tức thành phố Hải Phòng } 2019 \text { - năm } \\
2017 \text { Hải Phòng đón 6,7 triệu khách du lịch. }\end{array}$ \\
\hline $\begin{array}{l}\text { Sản xuất chế biến thuỷ } \\
\text { sản }\end{array}$ & $\begin{array}{l}75 \% \text { số lượng trong vùng kinh tế } \\
\text { trọng điểm Bắc bộ }\end{array}$ & Ủy ban nhân dân thành phố Hải Phòng 2015 \\
\hline Kho lạnh & $\begin{array}{l}50 \% \text { sức chứa các kho lạnh trong } \\
\text { các cơ sở chế biến thủy sản ở } \\
\text { miền Bắc }\end{array}$ & Ủy ban nhân dân thành phố Hải Phòng 2015 \\
\hline Năng lượng & 1 & Leonard 2018 \\
\hline Ngân hàng & 1 & Standard Chartered Bank 2012 \\
\hline Nguyên liệu thực phẩm & Một số công ty sản xuất đồ uống & Từ khảo sát thực địa của nhóm tác giả \\
\hline Xăng dầu & $\begin{array}{l}\text { Tốc độ tăng trường 2015-2017 là } \\
\text { 12.50\% }\end{array}$ & Bộ giao thông vận tải 2019 \\
\hline
\end{tabular}

kết quả nghiên cứu khoa học về vai trò của rừng ngập mặn trong việc cung ứng 2 dịch vụ trên. Cụ thể, chúng tôi sẽ làm rõ hiện trạng ô nhiễm và vai trò của hệ sinh thái rừng ngập mặn ở vùng cửa sông thành phố Hải Phòng, thông qua: - Đánh giá chất lượng nguồn nước và hiện trạng ô nhiễm các kim loại trong bề mặt trầm tích dọc theo hệ thống sông chảy qua Thành Phố Hải Phòng, bao gồm các cảng biển.
- Đánh giá vai trò của hệ sinh thái rừng ngập mặn đến khả năng tích lũy và làm giảm hàm lượng các chất ô nhiễm (kim loại và phi kim) trong nguồn nước của sông chảy qua hệ thống rừng.

Ngoài ra, chúng tôi cũng sẽ đánh giá lượng hấp thu các-bon mà rừng ngập mặn tại Hải Phòng có thể đem lại. 
Bảng 25. Người mua dịch vụ môi trường tiềm năng đối với RNM tại Việt Nam

\begin{tabular}{|c|c|c|c|}
\hline Người mua tiềm năng & Lợi ích & Khả năng chi trả & Cơ trúc phí \\
\hline $\begin{array}{l}\text { Người thu mua địa } \\
\text { phương }\end{array}$ & Thủy sản, gỗ & Thấp & Có giấy phép, thu ở cấp xã \\
\hline Ngư dân gần bờ & Thủy sản, bảo vệ ven bờ & Thấp & Tàu thuyền có giấy phép, thu ở cấp xã \\
\hline $\begin{array}{l}\text { Nuôi trồng } \\
\text { thủy sản }\end{array}$ & $\begin{array}{l}\text { Bảo vệ ven bờ, chất } \\
\text { lượng nước, chu kỳ dinh } \\
\text { dưỡng, hạt giống }\end{array}$ & Trung bình & $\begin{array}{l}\text { Các sản phẩm bền vững giá cao, thu qua } \\
\text { chuỗi cung ứng; hoặc dựa vào diện tích } \\
\text { nuôi trồng, thu ở cấp xã huyện }\end{array}$ \\
\hline Cảng và khu vực kinh tế & $\begin{array}{l}\text { Bảo vệ bờ biển, chất } \\
\text { lượng nước, chu kỳ dinh } \\
\text { dưỡng }\end{array}$ & Cao & Phí dịch vụ môi trường, cơ quan cảng thu \\
\hline $\begin{array}{l}\text { Công nghiệp và } \\
\text { phát triển ven biển }\end{array}$ & Bảo vệ bờ biển & Cao & $\begin{array}{l}\text { Phí dịch vụ môi trường, thu qua tỷ lệ giấy } \\
\text { chứng nhận sử dụng đất ở cấp huyện } \\
\text { hoặc cấp tỉnh }\end{array}$ \\
\hline Du lịch & $\begin{array}{l}\text { Giải trí, cảnh quan, môi } \\
\text { trường sống }\end{array}$ & Cao & $\begin{array}{l}\text { Giấy phép vào cửa, thu ở cổng hoặc trên } \\
\text { thuyền hoặc tại cổng, phí cơ sở hạ tầng, } \\
\text { thu qua thuế/phí }\end{array}$ \\
\hline Cộng đồng toàn cầu & Cacbon & Trung bình & $\begin{array}{l}\text { Chiến lược REDD+ Việt Nam hay Dự án } \\
\text { Quyền hạn, thu ở cấp quốc gia. }\end{array}$ \\
\hline
\end{tabular}

Nguồn: Sommerville 2016

\subsection{Mở rộng thêm nguồn thu cho bảo vệ rừng ngập mặn trong tương lai}

Cho tới nay, việc tìm kiếm và đảm bảo ngân sách cho bảo vệ rừng ngập mặn luôn gặp khó khăn. Ngay cả khi xác định được dịch vụ tiềm năng, việc chứng minh và vận hành cơ chế đó không hề dễ dàng. Tuy nhiên, việc Hải Phòng đã có sẵn Quỹ Phát triển bền vững khu dự trữ sinh quyển Cát Bà với một cơ chế huy động đóng góp tự nguyện của các bên liên quan. Sử dụng nguồn thu này có hiệu quả có thể là mô hình mà PFES nên xem xét để áp dụng (Hộp 2).

Việc có nhiều doanh nghiệp trong địa bàn tự nguyện đóng góp tiền bảo vệ môi trường, trong đó có dành ra ngân sách để trồng mới rừng ngập mặn, mở ra một cách tiếp cận mới trong việc thúc đẩy cơ chế tự nguyện của PFES tại Việt Nam đồng thời cũng cần có nhiều nghiển cứu hơn nữa về vấn đề này.

\section{Hộp 2. Cơ chế vận hành và gây quỹ của Quỹ phát triển bền vững khu dự trữ sinh quyển Cát Bà (Khu dự trữ sinh quyển Cát Bà 2020)}

Được thành lập từ năm 2010, Quỹ Phát triển Khu Dự trữ sinh quyển thế giới Quần đảo Cát Bà được hình thành không vì lợi nhuận trên cơ sở vận động sự tự nguyện tài trợ ủng hộ của các tổ chức cá nhân trong nước và ngoài nước, phục vụ cho công tác bảo tồn và phát triển bền vứng Khu DTSQ Cát Bà. Đây là sáng kiến hành động tiên phong của Khu Dự trữ sinh quyển thế giới Quần đảo Cát Bà, hưởng ứng lời kêu gọi từ Tuyên bố Madrid của Đại hội toàn cầu các Khu dự trữ sinh quyển thế giới lần thứ 3 tại Madrid (Tây Ban Nha), tháng 2/2008. Trong đó, các Khu DTSQ là cầu nối xây dựng những mối hợp tác lâu dài hiệu quả giữa chính quyền và doanh nghiệp trong lĩnh vực phát triển bền vững, thích ứng và giảm nhẹ biến đổi khí hậu.

Các hoạt động cụ thể theo điều lệ của Quỹ: 
Hộp 2. Tiếp trang trước

Hỗ trợ thực hiện việc bảo tồn và phát triển bền vững Khu Dự trữ sinh quyển Quần đảo Cát Bà theo quy định của pháp luật và Điều lệ Quỹ;

- Cho vay đầu tư;

- Hỗ trợ có hoàn lại vốn gốc;

- Nhận ủy thác và ủy thác cho vay, hỗ trợ;

- Tiếp nhận, quản lý và sử dụng các nguồn tài trợ, viện trợ từ các tổ chức, cá nhân trong và ngoài nước để phục vụ cho công tác bảo tồn và phát triển bền vững Khu Dự trữ sinh quyển thế giới Quần đảo Cát Bà.

- Các hoạt động khác theo quy định của pháp luật và Điều lệ Quỹ.

- Quỹ đang xem xét, kiện toàn, chuyển hoạt động theo mô hình doanh nghiệp xã hội theo Nghị định 96/2015/NĐ-CP ngày 19/10/2015 (Điều 7. Chuyển cơ sở bảo trợ xã hội, quỹ xã hội và quỹ từ thiện thành doanh nghiệp xã hội).

Quỹ được Tập đoàn Thép Việt Nhật khởi xướng, thỏa thuận cùng Ủy ban Quốc gia Chương trình Con người và Sinh quyển (MAB) Việt Nam và một số doanh nghiệp, cá nhân có tâm huyết về bảo tồn, bảo vệ môi trường tự nguyện đóng góp tài chính. Ban sáng lập viên thành lập Quỹ gồm:

- Công ty Cổ phần Thép Việt Nhật;

- Công ty Cổ phần Công nghiệp tàu thủy Shinec;

- Công ty TNHH Lê Quốc;

- Công ty TNHH Thép VPS-POSCO;

- Công ty TNHH Muối Khánh Vinh;

- Tổng công ty Xây dựng Bạch Đằng, Bộ Xây dựng;

- Công ty Điện chiếu sáng đô thị;

- Công ty Cổ phần Đầu tư Sao Đỏ.

Tổng hợp Quỹ Phát triển bền vững Khu DTSQ thế giới Quần đảo Cát Bà đến ngày 30/6/2016 có số dư tài khoản: 475,014,535 đồng, bao gồm đóng góp, hỗ trợ của các tổ chức, cá nhân trong và ngoài nước (Nguồn: Báo cáo của BQL Quỹ), cụ thể:

1. Công ty cổ phần đầu tư Sao đỏ: $50,000,000$ đồng;

2. Công ty TNHH Thép VSCPOSCO : $150,000,000$ đồng;

3. Công ty điện chiếu sáng Hải Phòng : 50,000,000 đồng;

4. Tổng Công ty xây dựng Bạch Đằng : 50,000,000 đồng;

5. Công ty Cổ phần xây dựng An Vinh: $30,000,000$ đồng;

6. Công ty TNHH Nhật Việt: $40,000,000$ đông;

7. Giáo sư Ockie Boch, Đại Học Queensland: 28,072,335 đông

8. Cty CP Đầu tư Quốc tế Hùng Vương - Hùng Việt: 50,000,000 đồng

9. Tiền lãi của Quỹ: $26,942,200$ đồng 


\section{Tài liệu tham khảo}

Accioly AM, Siqueira JO. 2000. Contaminação química e biorremediação do solo. In Novais RF, Avarez VH, Schaefer CE, eds. Tópicos em ciência do solo. Viçosa: Sociedade Brasileira de Ciência do Solo. 299-352.

Aerts R and Honnay O. 2011. Forest restoration, biodiversity and ecosystem functioning. BMC ecology 11(1):210. https://link.springer.com/ article/10.1186/1472-6785-11-29

Alguacil MM, Torres MP, Torrecillas E, Díaz G and Roldán A. 2011. Plant type differently promote the arbuscular mycorrhizal fungi biodiversity in the rhizosphere after revegetation of a degraded, semiarid land. Soil Biology and Biochemistry 43(1):167-73. https://doi. org/10.1016/j.soilbio.2010.09.029

Almeida ROPO. 2010. Indicadores da qualidade do substrato para monitoramento de áreas revegetadas: estudo dirigido à mineração de areia. São Paulo, Brazil: University of São Paulo. https://www.teses.usp.br/ teses/disponiveis/3/3134/tde-23082010093625/en.php

Al-Momani IF. 2009. Assessment of trace metal distribution and contamination in surface soils of Amman, Jordan. Jordan J Chem 4(1): 77-87.

Alongi DM. 2012. Carbon sequestration in mangrove forests. Carbon management 3(3):313-22.

Amador DB. 1999. Restauração de ecossistemas com sistemas agroflorestais. Piracicaba: Embrapa. https://www.naturefund.de/ fileadmin/pdf/Agroforst/Neu/Denise $\% 20$ Bittencourt\%20Amador\%2C\%20 Restaura\%C3\%A7\%C3\%A3o\%20de\%20 Ecossistemas\%20com\%20Sistemas\%20 Agroflorestais.pdf

Ambus R and Lowrance R. 1991. Comparision of denitrification in two riparian soils.
Soil Science Society of America Journal 95:994-7.

Armando MS, Bueno YM, Alves EDS and Cavalcante CH. 2002. Agrofloresta para agricultura familiar. Brazil: Ministry of Agriculture, Livestock, and Supply. https://www.infoteca.cnptia.embrapa. $\mathrm{br} /$ bitstream/doc/184803/1/ct016.pdf

Ashton MS, Gunatilleke CVS, Singhakumara BMP and Gunatilleke IAUN. 2001. Restoration pathways for rain forest in southwest Sri Lanka: a review of concepts and models. Forest ecology and management 154(3):409-30. https://doi. org/10.1016/S0378-1127(01)00512-6

Bandaranayake W. 1998. Traditional and medicinal uses of mangroves. Mangroves and Salt Marshes 2(3):133-48.

Báo điện tử Chính phủ. 2018. Quyết định số 821/QĐ-TTg ngày 06/07/2018 về phê duyệt điều chỉnh, bổ sung Quy hoạch tổng thể phát triển kinh tế-xã hội thành phố Hải Phòng đến năm 2025, định hướng đến năm 2030. Truy cập ngày 02 tháng 6 năm 2020. http://vanban. chinhphu.vn/portal/page/portal/ chinhphu/hethongvanban?class_id $=2 \&$ page $=1 \&$ mode $=$ detail\&document_ id $=194125$.

Barbier EB, Koch EW, Silliman BR, Hacker SD, Wolanski E, Primavera J, Granek EF, Polasky S, Aswani S, Cramer LA, and Stoms DM. 2008. Coastal ecosystembased management with nonlinear ecological functions and values. Science 319:321-3.

Beck MW, Losada IJ, Menéndez P, Reguero BG, Díaz-Simal P and Fernández F. 2018. The global flood protection savings provided by coral reefs. Nature communications 9(1): 1-9.

Berkowitz B, Dror I and Yaron B. 2008. Contaminant Geochemistry: Interactions 
and Transport. The Subsurface Environment. Springer, Heidelberg: 412.

Berner RA and Raiswell R. 1983. Burial of organic các-bon and pyrite sulfur in sediments over Phanerozoi time: a new theory. Geochimica et Cosmochimica Acta 47:855-62.

Berner RA. 1984. Sedimentary pyrite formation: An update. Geochimica et Cosmochimica Acta 48:605-15.

Boris van Zanten, Francielle L, Sacha van Duren, Vanessa S and Pieter van Beukering. 2018. The Value Natural Capital for the Tourism Industry of Aruba. Wolfs Company. Truy cập ngày 02 tháng 6 năm 2020. https:// www.wolfscompany.com/wp-content/ uploads/2018/04/The-Tourism-Value-ofNature.pdf.

Bộ giao thông vận tải. 2018. BÁO CÁO TỔNG HỢP GIAI ĐOẠN II Dự án bảo vệ môi trường: "Nghiên cứu thiết lập vùng biển đặc biệt nhạy cảm (PSSAs) tại Việt Nam".

Bộ giao thông vận tải. 2019. Vinalines sắp đâu tư cụm cảng và tổng kho xăng dâu tại Hải Phòng. Truy cập ngày 02 tháng 6 năm 2020. http://www.mt.gov.vn/vn/tin-tuc/61774/ vinalines-sap-dau-tu-cum-cang-va-tongkho-xang-dau-tai-hai-phong.aspx.

Bray S and Langston WJ. 2006. Tributyltin pollution on a global scale. An overview of relevant and recent research: impacts and issues. Report submitted to Marine Environment protection committee. 55th session. MEPC, 55. Truy cập ngày 02 tháng 6 năm 2020. http://assets.wwf.no/ downloads/tbt_global_review_wwf_uk_ oct_2006.pdf.

Brienza JS, Vieira ICG and Yared JAG. 1995. Considerações sobre recuperação de áreas alteradas por atividades agropecuária e florestal na Amazônia brasileira. Belém: Brazil: EMBRAPA-CPATU. https://www. infoteca.cnptia.embrapa.br/bitstream/ doc/374321/1/CPATUDoc83.pdf

Butler RA. 2013. Disney buys $\$ 3.5 \mathrm{M}$ in REDD credits from rainforest conservation project in Peru. https://news.mongabay. com/2013/03/disney-buys-3-5m-in-reddcredits-from-rainforest-conservationproject-in-peru/

Cảng Hàng không Quốc tế Cát Bi. 2020. Hải Phòng: Việt Nam. https://www. vietnamairport.vn/catbiairport/.
Caproni AL, Franco AA, Berbara RLL, Granha JRDDO and Marinho NF. 2005. Fungos micorrízicos arbusculares em estéril revegetado com Acacia mangium, após mineração de bauxita. Revista Árvore 29(3):373-81. https://www.scielo.br/ pdf/rarv/v29n3/a04v29n3.pdf

Carnevale NJ and Montagnini F. 2002. Facilitating regeneration of secondary forests with the use of mixed and pure plantations of indigenous tree species. Forest ecology and management 163(1-3):217-27. https://doi. org/10.1016/S0378-1127(01)00581-3

[CCICED] China Council for International Cooperation on Environment and Development. 2006. Eco-Compensation Mechanisms and Policies in China. Truy cập ngày 02 tháng 6 năm 2020. http://www. caep.org.cn/ywlm/home/working_pagers_ and_reports/working_papers/201809/ W020180929352237812863.pdf.

Con người và thiên nhiên. 2008. Tributyltin đã có mặt trong danh sách hóa chất độc hại quốc tế. Truy cập ngày 02 tháng 6 năm 2020. https://www.thiennhien.net/2008/11/15/ tributyltin-da-co-mat-trong-danh-sachhoa-chat-doc-hai-quoc-te/.

Cổng tin tức Thành phố Hải Phòng. 2019. Thành phố đón trên 6,7 triệu lượt khách du lịch. Truy cập ngày 02 tháng 6 năm 2020. https:// thanhphohaiphong.gov.vn/thanh-phodon-tren-67-trieu-luot-khach-du-lich.html.

Cổng thông tin điện tử Bộ Giao thông Vận tải. 2011. Phát triển hệ thống cảng biển: Nhìn từ góc độ bảo vệ môi trường biển 2010. Truy cập ngày 02 tháng 6 năm 2020. http:// www.mt.gov.vn/moitruong/quy-chuanchat-luong/21150/phat-trien-he-thongcang-bien--nhin-tu-goc-do-bao-ve-moitruong-bien-2010.aspx.

Cơ sở dữ liệu Thông tin doanh nghiệp. 2020. Thông tin doanh nghiệp khai thác khoáng sản. https://thongtindoanhnghiep.co/ tim-kiem?location $=\% 2$ Fhaiphong\&kwd= Khai+th\%C3\%A1c+kho\%C3\%A1ng+s\%E $1 \% \mathrm{BA} \% \mathrm{~A} 3 \mathrm{n}$

Cục điều tiết điện lực. 2015. Quyết định 79/QDDTDL Ban hành danh sách nhà máy điện tham gia Thị trường phát điện cạnh tranh năm 2016. Bộ Công thương, Cục điêu tiết điện lực. Truy cập ngày 02 tháng 6 năm 2020. http://www.erav.vn/d4/van-ban/Quyet- 
dinh-ban-hanh-Danh-sach-nha-may-dientham-gia-Thi-truong-phat-dien-canh-tranhVCGM-nam-2016-4-827.aspx.

Cục điều tiết điện lực. 2017. Quyết định 95/QDDTDL Ban hành danh sách nhà máy điện tham gia Thị trường phát điện cạnh tranh năm 2018. Bộ Công thương, Cục điều tiết điện lực. Truy cập ngày 02 tháng 6 năm 2020. http://www.erav.vn/d4/van-ban/Quyetdinh-ban-hanh-Danh-sach-nha-may-dientham-gia-Thi-truong-phat-dien-canhtranh-nam-2018--4-951.aspx.

Cục điều tra và kiểm soát tài nguyên môi trường biển. 2013. Dựán kiểm soát ô môi trường biển do các hoạt động kinh tế-xã hội vùng biển Quảng Ninh- Hải Phòng, Đà Nẵng-Quảng Nam và Bà Rịa Vũng Tàuthành phố Hồ Chí Minh. Kế hoạch kiểm soát ô môi trường biển khu vực Quảng Ninh - Hải Phòng. Truy cập ngày 02 tháng 6 năm 2020. https://www.quangninh. gov.vn/So/sotainguyenmt/Lists/TinTuc/ Attachments/630/Ke\%20hoach\%20 KSONB\%20Hai\%20Phong\%20-\%20 Quang\%20Ninh.pdf.

Cục Hàng hải Việt Nam. 2013. Bảo vệ môi trường trong hoạt động vận tải biển. Truy cập ngày 02 tháng 6 năm 2020. http://www. vinamarine.gov.vn/vi/tin-tuc/bao-ve-moitruong-trong-hoat-dong-van-tai-bien.

Cục hàng hải Việt Nam. 2015. Dự thảo báo cáo nghiên cứu xác định khu vực biển đặc biệt nhạy cảm Hạ Long-Cát Bà. Truy cập ngày 02 tháng 6 năm 2020. http://www. vinamarine.gov.vn/sites/default/files/ Bao\%20cao\%20ky\%202\%20PSSA\%20 23.12.2015\%20-\%20Tu\%20Anh.pdf

Cục hàng hải Việt Nam. 2018. BÁO CÁO TỔNG HỢP GIAI ĐOAN II Dựán bảo vệ môi trường: "Nghiên cứu thiết lập vùng biển đặc biệt nhạy cảm (PSSAs) tại Việt Nam". Hà Nội: Bộ Giao thông vận tải.

Cusack D and Montagnini F. 2004. The role of native species plantations in recovery of understory woody diversity in degraded pasturelands of Costa Rica. Forest Ecology and management 188(1-3):1-15. https:// doi.org/10.1016/S0378-1127(03)00302-5

Cheng $\mathrm{H}$, Wang M, Wong MH and Ye Z. 2014. Does radial oxygen loss and iron plaque formation on roots alter $\mathrm{Cd}$ and $\mathrm{Pb}$ uptake and distribution in rice plant issues?. Plant and soil 375(1-2): 137-48.
Chính phủ Việt Nam. 2007. Nghi quyết số 09-NQ/ TW ngày 09/02/2017 về chiến lược biển Việt Nam đến năm 2020.

Chính phủ Việt Nam. 2016. Nghị định số 164/2016/NO-CP ngày 24/12/2016 vê phí bảo vệ môi trường đối với khai thác khoáng sản. Truy cập ngày 02 tháng 6 năm 2020. https://thuvienphapluat.vn/van-ban/tainguyen-moi-truong/Nghi-dinh-164-2016ND-CP-ve-phi-bao-ve-moi-truong-doi-voikhai-thac-khoang-san-325915.aspx.

Defew LH ,Mair JM and Guzman HM. 2005. An assessment of metal contamination in mangrove sediments and leaves from Punta Mala Bay, Pacific Panama. Marine pollution bulletin 50(5):547-52.

Donato DC, Kauffman JB, Murdiyarso D, Kurnianto S, Stidham M and Kanninen M. 2012. Rừng ngập mặn trong những kiểu rừng giàu trữ lượng các-bon nhất ở vùng nhiệt đới. CIFOR Brief 13.

Donato DC, Kauffman JB, Murdiyarso D, Kurnianto S, Stidham M, Kanninen M. 2011. Mangroves among the most carbon-rich forests in the tropics. Nature geoscience 4:293-7.

Dunbabin JS and Bowmer KH. 1992. Potential use of constructed wetlands for treatment of industrial wastewaters containing metals. Science of the Total environment 111(2-3): 151-68.

Dương VM. 2018. Các khu kinh tế ven biển Việt Nam: Tăng cường đổi mới công nghệ, giảm thiểu phát thải khí nhà kính. Tạp chí môi trường số 2/2018. Truy cập ngày 02 tháng 6 năm 2020. http://tapchimoitruong. vn/pages/article.aspx?item $=$ C\%C3\%A1ckhu-kinh-t\%E1\%BA\%BF-venbi\%E1\%BB\%83n-Vi\%E1\%BB\%87t-Nam:T\%C4\%83ng-c\%C6\%B0\%E1\%BB\%9Dng\%C4\%91\%E1\%BB\%95i-m\%E1\%BB\%9Bic\%C3\%B4ng-ngh\%E1\%BB\%87,gi\%E1\%BA\%A3m-thi\%E1\%BB\%83uph\%C3\%A1t-th\%E1\%BA\%A3i-kh\%C3\%ADnh\%C3\%A0-k\%C3\%ADnh-48095.

Eimskip Vietnam. 2018. Chi Phí Nhiên Liệu Trong Vận Tải Biển. Truy cập ngày 02 tháng 6 năm 2020. http://logisticsinvietnam.vn/chiphi-nhien-lieu-trong-van-tai-bien/.

[EPA] United States Environmental Protection Agency. 2005. Shipyard Stormwater Best Management Practices No. 6: Thermal Metal Cutting. 
Fávero C, Lovo IC and Mendonça EDS. 2008. Recuperação de área degradada com sistema agroflorestal no Vale do Rio Doce, Minas Gerais. Revista Árvore 32(5):861-8. https://www.scielo.br/pdf/rarv/v32n5/11. pdf

Fernandes LS. 2004. Avaliação de mantas comerciais na vegetação de talude em corte de estrada. Viçosa, Brazil: Universidade Federal de Viçosa. https://www.locus.ufv. br/bitstream/handle/123456789/9312/ texto\%20completo.pdf

Galas ND. 2006. Uso da vegetação para contenção e combate à erosão em taludes. São Paulo: Anhembi Morumbi University.

Global Commission on Adaptation. 2019. ADAPT NOW: A GLOBAL CALL FOR LEADERSHIP ON CLIMATE RESILIENCE. Truy cập ngày 02 tháng 6 năm 2020. https://cdn.gca.org/assets/2019-09/ GlobalCommission_Report_FINAL.pdf.

Grubb PJ. 1995. Mineral nutrition and soil fertility in tropical rain forests. In Lugo AE and Lowe C, eds. Tropical forests: management and ecology. New York, Springer. 308-30. https://link.springer.com/ chapter/10.1007/978-1-4612-2498-3_12

Guariguata MR, Rheingans R and Montagnini F. 1995. Early woody invasion under tree plantations in Costa Rica: implications for forest restoration. Restoration Ecology 3(4):252-60. https://doi. org/10.1111/j.1526-100X.1995.tb00092.x

Guerrero E, Rivillas C and Rivera E. 1996. Perspectivas de manejo de la micorriza arbuscular en ecosistemas tropicales. In Forero EG and Azcon C, eds. Micorrizas: Recurso Biológico del suelo. Bogotá, Fondo FEN Colombia. 181-201

Giri C, Ochieng E, Tieszen LL, Zhu Z, Singh A, Loveland T, Masek J and Duke, N. 2011. Status and distribution of mangrove forests of the world using earth observation satellite data. Global Ecology and Biogeography 20(1): 154-9.

Hà XC. 2009. Các tác động môi trường trong quá trình xây dựng và khai thác cảng biển. Tạp chí khoa học Hàng hải (17):52-4.

Haggar J, Wightman K and Fisher R. 1997. The potential of plantations to foster woody regeneration within a deforested landscape in lowland Costa Rica. Forest Ecology and
Management 99(1-2):55-64. https://doi. org/10.1016/S0378-1127(97)00194-1

Harbison P. 1986. Mangrove muds-a sink and a source for trace metals. Marine Pollution Bulletin 17(6): 246-50.

Hải Đ. 2014. Cần xử lý nghiêm ô nhiễm ở Nhà máy Gang thép Vạn Lợi. https:// baoxaydung.com.vn/can-xu-ly-nghiemo-nhiem-o-nha-may-gang-thep-vanloi-99259.html

Hiệp L. 2018. Hải Phòng lập lại trật tự đội tàu du lịch biển, Kỳ 1. Du lịch. Truy cập ngày 02 tháng 6 năm 2020. http://baodulich.net.vn/ Hai-Phong-lap-lai-trat-tu-doi-tau-du-lichbien-Ky-1-24-15514.html.

Hoàng T. 2017. Thiệt hại do chậm nạo vét luồng hàng hải Hải Phòng. Nhân dân. Truy cập ngày 02 tháng 6 năm 2020. https://www. nhandan.com.vn/kinhte/item/35029902thiet-hai-do-cham-nao-vet-luong-hanghai-hai-phong.html.

Holanda FS, Rocha IPD and Oliveira VS. 2008. Riverbank stabilization with soil bioengineering techniques at the Lower São Francisco River. Revista Brasileira de Engenharia Agrícola e Ambiental 12(6):5705. https://www.researchgate.net/ publication/265843169_Riverbank_ stabilization_with_soil_bioengineering_ techniques_at_the_Lower_Sao_ Francisco_River

Hội Đồng Nhân Dân thành phố Hải Phòng. 2014. Nghị quyết 33/2014/NQ-HĐND về thông qua quy hoạch tài nguyên nước thành phố Hải Phòng đến năm 2020, tâm nhìn đến năm 2030.

Jeddi K and Chaieb M. 2012. Restoring degraded arid Mediterranean areas with exotic tree species: Influence of an age sequence of Acacia salicina on soil and vegetation dynamics. FloraMorphology, Distribution, Functional Ecology of Plants 207(9):693-700. https://doi. org/10.1016/j.flora.2012.07.002

The project for environmental protection in $\mathrm{Ha}$ Long Bay. Hanoi: Nippon Koei Co., Ltd.

Jose S. 2009. Agroforestry for ecosystem services and environmental benefits: an overview. Agroforestry systems 76(1):1-10. https://link.springer.com/article/10.1007/ s10457-009-9229-7

Kadlec R, Knight R, Vymazal J, Brix H, Cooper P and Haberl R. 2000. Constructed wetlands 
for pollution control: processes, performance, design and operation. IWA publishing.

Keenan R, Lamb D, Woldring O, Irvine T and Jensen R. 1997. Restoration of plant biodiversity beneath tropical tree plantations in Northern Australia. Forest Ecology and Management 99(1-2):11731. https://doi.org/10.1016/S03781127(97)00198-9

Keenan RJ, Lamb D, Parrotta J and Kikkawa J. 1999. Ecosystem management in tropical timber plantations: satisfying economic, conservation, and social objectives. Journal of Sustainable Forestry 9(1-2):117-34. https://doi.org/10.1300/J091v09n01_10

Kill J. 2014. Trade in Ecosystem Services. When Payment for Environmental Services Delivers a Permit to Destroy. World Rainforest Movement. Truy cập ngày 02 tháng 6 năm 2020. https://www.wrm.org.uy/html/ wp-content/uploads/2014/04/Trade-inEcosystem-Services.pdf.

Kjerfve B and Magill KE. 1989. Geographic and hydrodynamic charactersistics of shallow coastal lagoons. Marine Geology 88: 187-99.

Knapik P and Maranho LT. 2007. Avaliação da revegetação em área de mineração, região de inundação do rio Iguaçu, Araucária, PR. Revista Brasileira de Biociências 5(S1):507-9. http://www.ufrgs. br/seerbio/ojs/index.php/rbb/article/ viewFile/516/425

Kobayashi S. 2004. Landscape rehabilitation of degraded tropical forest ecosystems: case study of the CIFOR/Japan project in Indonesia and Peru. Forest Ecology and Management 201(1):13-22. https://doi. org/10.1016/j.foreco.2004.06.009

Kura B, Kambham K, Sangameswaran S and Potana S. 2006. Atmospheric particulate emissions from dry abrasive blasting using coal slag. Journal of the Air \& Waste Management Association 56(8): 1205-15.

Kuusipalo J, Ådjers G, Jafarsidik Y, Otsamo A, Tuomela K and Vuokko R. 1995. Restoration of natural vegetation in degraded Imperata cylindrica grassland: understorey development in forest plantations. Journal of Vegetation Science 6(2):205-10. https:// doi.org/10.2307/3236215

Khu dự trữ sinh quyển Cát Bà. 2020. Hải Phòng: Việt Nam. Truy cập ngày 02 tháng 6 năm 2020. http://catba.net.vn/.
Lamb D and Tomlinson M. 1994. Forest rehabilitation in the Asia-Pacific region: past lessons and present uncertainties. Journal of Tropical Forest Science 7(1):157-70. https://www.jstor.org/ stable $/ 43581800$ ?seq $=1$

Larison JR, Likens GE, Fitzpatrick JW and Crock JG. 2000. Cadmium toxicity among wildlife in the Colorado Rocky Mountains. Nature 406 (6792): 181-3.

Lemes MRT. 2001. Revisão dos efeitos da vegetação em taludes. Porto Alegre, Brazil: Federal University of Rio Grande do Sul. https://www.lume.ufrgs.br/ handle/10183/1675

Leonard N. 2018. Final report on a 7-year reforestation project implemented on $\mathrm{Cat} \mathrm{Ba}$ Island in Vietnam.

Lê TA. 2015. Phân tích hiện trạng chất lượng nước Vịnh Hạ Long, tỉnh Quảng Ninh, Việt Nam: Một nghiên cứu xã hội học từ góc nhìn của các doanh nghiệp du lịch. Gland, Thụy Sĩ: IUCN.

Lê XT, Phan NH và Trương QH. 2008. Những vấn đề môi trường ven biển và phục hôi rừng ngập mặn ở Việt Nam. Truy cập ngày 02 tháng 6 năm 2020. https://repository.vnu. edu.vn/bitstream/VNU_123/20795/1/22. pdf.

Lugo AE. 1997. The apparent paradox of reestablishing species richness on degraded lands with tree monocultures. Forest ecology and management 99(1-2):9-19. https://doi. org/10.1016/S0378-1127(97)00191-6

Luis CB and El-Hifnawi MB. 2014. Facilitating trade through competitive, low-carbon transport: the case for Vietnam's inland and coastal waterways. The World Bank. Truy cập ngày 02 tháng 6 năm 2020. http://documents.worldbank.org/ curated/en/800501468320727668/pdf/ Facilitating-trade-through-competitivelow-carbon-transport-the-case-forVietnams-inland-and-coastal-waterways. pdf.

Macedo MO, Resende AS, Garcia PC, Boddey RM, Jantalia CP, Urquiaga S, Campello EFC and Franco AA. 2008. Changes in soil $\mathrm{C}$ and $\mathrm{N}$ stocks and nutrient dynamics 13 years after recovery of degraded land using leguminous nitrogen-fixing trees. Forest Ecology and Management 255(5- 
6):1516-24. https://doi.org/10.1016/j. foreco.2007.11.007

Machado AADS, Spencer K, Kloas W, Toffolon M and Zarfl C. 2016. Metal fate and effects in estuaries: A review and conceptual model for better understanding of toxicity. Science of The Total Environment 541:268-81.

Mai L. 2019. Phát triển dịch vụ logistics tại Hải Phòng: Hướng tới trung tâm logistics tâm cỡ quốc gia, quốc tế. Truy cập ngày 02 tháng 6 năm 2020. http://haiphongdpi. gov.vn/2019/07/29/phat-trien-dich-vulogistics-tai-hai-phong-huong-toi-trungtam-logistics-tam-co-quoc-gia-quoc-te/.

Marchand C, Allenbach $\mathrm{M}$ and Lallier-Vergès $\mathrm{E}$. 2011. Relationships between heavy metals distribution and organic matter cycling in mangrove sediments (Conception Bay, New Caledonia). Geoderma 160(3-4): 444-56.

MARD. 2010. Biến đổi khí hậu và những ảnh hưởng lên nghề cá tại các khu vực rừng ngập mặn ven biển. Truy cập ngày 24/02/2020: https://www.mard.gov.vn/Pages/bien-doikhi-hau-va-nhung-anh-huong-len-ngheca-tai-cac-khu-vuc-rung-ngap-man-venbien-4378.aspx.

Maskaoui K, Zhou JL, Hong HS and Zhang ZL. 2002. Contamination by polycyclic aromatic hydrocarbons in the Jiulong River estuary and Western Xiamen Sea, China. Environmental pollution 118(1): 109-22.

McNamara S, Duong VT, Erskine PD, Lamb D, Yates D and Brown S. 2006. Rehabilitating degraded forest land in central Vietnam with mixed native species plantings. Forest Ecology and Management 233(2-

3):358-65. https://doi.org/10.1016/j. foreco.2006.05.033

Melo IS and Azevedo JL. 1998. Ecologia microbiana. Jaguariúna: Embrapa-CNPMA.

Minh A. 2017. Công ty Indonesia sắp xây cảng vận chuyển than 1 tỷ USD ở Việt Nam. Truy cập ngày 02 tháng 6 năm 2020. https:// cafef.vn/cong-ty-indonesia-sap-xaycang-van-chuyen-than-1-ty-usd-o-vietnam-20170824141337631.chn.

Montagnini F. 2000. Strategies for the recovery of biodiversity in deforested landscapes. In Krishnapillay B, Soepadmo E, Arshad NL, Wong AHH, Appanah S, Chik SW, Manokaran N, Tong HL, Choon KK, eds. Forests and Society: The Role of Research. Vol. 1. IUFRO World Congress. Subplenary Sessions. Kuala
Lumpur, Malaysia: International Union of Forestry Research Organizations. 310-9. https://www.academia.edu/6861801/ FORESTS_AND_SOCIETY_THE_ROLE_OF_ RESEARCH

Moreira PR. 2004. Manejo do solo e recomposição da vegetação com vistas a recuperação de áreas degradadas pela extração de bauxita, Poços de Caldas, MG. São Paulo, Brazil: São Paulo State University. https://repositorio. unesp.br/handle/11449/100645

Mumby PJ, Edwards AJ, Arias-González JE, Lindeman KC, Blackwell PG, Gall A, Gorczynska MI, Harborne AR, Pescod CL, Renken $\mathrm{H}$ and Wabnitz CC. 2004. Mangroves enhance the biomass of coral reef fish communities in the Caribbean. Nature 427(6974): 533-6.

Nawir AA, Murniati, Rumboko L, eds. 2007. Forest rehabilitation in Indonesia: where to after more than three decades? Bogor, Indonesia: Center for International Forestry Research. https://www.cifor.org/ knowledge/publication/2274/

Newsham KK, Fitter AH and Watkinson AR. 1995. Multi-functionality and biodiversity in arbuscular mycorrhizas. Trends in Ecology \& Evolution 10(10):407-11. https://doi. org/10.1016/S0169-5347(00)89157-0

Nriagu JO and Pacyna JM. 1988. Quantitative assessment of worldwide contamination of air, water and soils with trace metals. Nature 333:134-9.

Nghiêm G và Bùi HT. 2016. Nâng cao hiệu quả bảo vệ môi trường trong ngành thép Việt Nam. Tạp chí môi trường số 12/2016. Truy cập ngày 02 tháng 6 năm 2020. http://tapchimoitruong.vn/pages/ article.aspx?item=N\%C3\%A2ng-caohi\%E1\%BB\%87u-qu\%E1\%BA\%A3b\%E1\%BA\%A3o-v\%E1\%BB\%87m\%C3\%B4i-tr\%C6\%B0\%E1\%BB\%9Dngtrong-ng\%C3\%A0nh-th\%C3\%A9pVi\%E1\%BB\%87t-Nam-45473.

Ngô XQ và Nguyễn TMY. 2017. Tác động của Tributyltin lên cấu trúc giới tính quần xã tuyến trùng sống tự do sông Sài Gòn, thành phố Hồ Chí Minh. Tạp chícông nghệ sinh hoc 15(3A): 1-7

Nguyễn CN. 2019. Định hướng phát triển bền vững Ngành Than Việt Nam gắn với đảm bảo an ninh năng lượng. Truy cập ngày 02 tháng 6 năm 2020. http:// www.vinacomin.vn/dinh-huong-phat- 
trien-ben-vung-nganh-than-viet-namgan-voi-dam-bao-an-ninh-nang-luong/ dinh-huong-phat-trien-ben-vung-nganhthan-viet-nam-gan-voi-dam-bao-an-ninhnang-luong-201901181507032041.htm.

Nguyễn CH. 2012. Đâuu tư cho các hệ sinh thái vùng bở biển: Tài liệu Hướng dẫn cho các Nhà báo vê vai trò của các Hệ sinh thái Vùng bờ biển. Rừng ngập mặn cho Tương lai. Gland, Thụy Sĩ: IUCN.

Nguyễn TMH. 2015. Nghiên cứu cơ sở pháp lý và thực tiễn về hoạt động đổ thải chất nạo vét luônng cảng tại thành phố Hải Phòng [Luận văn Thạc sỹ]. Hà Nội: Đại học quốc gia Hà Nội. https://repository.vnu.edu.vn/ handle/VNU_123/13877

Nguyễn TP. 2017. Kiểm soát ô nhiễm môi trường vùng cửa sông, ven biển Hải Phòng. Tạp chí Môi trường số 4/2017. Truy cập ngày 02 tháng 6 năm 2020. http://tapchimoitruong.vn/pages/ article.aspx?item $=\mathrm{Ki} \% \mathrm{E} 1 \% \mathrm{BB} \% 83 \mathrm{~m}$ so\%C3\%A1t-\%C3\%B4-nhi\%E1\%BB\%85mm\%C3\%B4i-tr\%C6\%B0\%E1\%BB\%9Dngv\%C3\%B9ng-C\%E1\%BB\%ADas\%C3\%B4ng,-ven-bi\%E1\%BB\%83nH\%E1\%BA\%A3i-Ph\%C3\%B2ng-46094.

Nguyễn THL and Nguyễn VQ. 2014. Hướng tới phát triển công cụ chi trả dịch vụ hệ sinh thái biển ở Việt Nam. Tạp chí Môi trường số 6 . Truy cập ngày 02 tháng 6 năm 2020. http://tapchimoitruong.vn/pages/article. aspx?item $=\mathrm{H} \% \mathrm{C} 6 \% \mathrm{~B} 0 \% \mathrm{E} 1 \% \mathrm{BB} \% 9 \mathrm{Bng}$ t\%E1\%BB\%9Bi-ph\%C3\%A1ttri\%E1\%BB\%83n-c\%C3\%B4ngC\%E1\%BB\%A5-chi-tr\%E1\%BA\%A3d\%E1\%BB\%8Bch-v\%E1\%BB\%A5h\%E1\%BB\%87-sinh-th\%C3\%A1ibi\%E1\%BB\%83n-\%E1\%BB\%9FVi\%E1\%BB\%87t-Nam-38459.

Nguyễn XH và Nguyễn NH. 2017. Báo cáo ngành thép. Công ty cổ phân chứng khoán FPT. Truy cập ngày 02 tháng 6 năm 2020. http://www.fpts.com.vn/FileStore2/ File/2019/3/12/FPA_Cap_nhat_nganh_ Thep_T.pdf

OECD Council Working Party on Shipbuilding. 2010. Environmental and climate change issues in the shipbuilding industry. Truy cập ngày 02 tháng 6 năm 2020. https://www. oecd.org/sti/ind/46370308.pdf.

OSHA. 2006. Abrasive Blasting Bazards in Shipyard Employment. United States Occupational Safety and Health
Administration. Truy cập ngày 02 tháng 6 năm 2020. https://www.osha.gov/dts/ maritime/standards/guidance/shipyard_ guidance.html.

Parrotta JA, Turnbull JW and Jones N. 1997. Catalyzing native forest regeneration on degraded tropical lands. Forest Ecology and Management 99(1-2):1-7. https://doi. org/10.1016/S0378-1127(97)00190-4

Parrotta JA. 1992. The role of plantation forests in rehabilitating degraded tropical ecosystems. Agriculture, ecosystems \& environment 41(2):115-33. https://doi. org/10.1016/0167-8809(92)90105-K

Pereira BDA and Castro-Silva MA. 2010. Rizobactérias formadoras de endósporos associadas a Tibouchina urvilleana de áreas impactadas por rejeitos da mineração do carvão. Revista Brasileira de Ciência do Solo 34(2):563-7. https://www.scielo.br/ pdf/rbcs/v34n2/v34n2a30.pdf

Pinheiro DJF. 1971. Evolução das encostas nas regiões tropicais úmidas. Salvador: Federal University of Bahia.

Pires F, Souza C, Silva A, Procópio S and Ferreira L. 2003. Fitorremediação de solos contaminados com herbicidas. Planta daninha 21(2):335-41. https://www.scielo. $\mathrm{br} / \mathrm{pdf} / \mathrm{pd} / \mathrm{v} 21 \mathrm{n} 2 / \mathrm{a} 20 \mathrm{v} 21 \mathrm{n} 2 . \mathrm{pdf}$

Popak AE. 2012. Mining and ecosystem service. Conferences paper of 2 Conferência da REDE de Lingua Portuguesa de Avaliação de Impactos Ambientais.

Powers JS, Haggar JP and Fisher RF. 1997. The effect of overstory composition on understory woody regeneration and species richness in 7-year-old plantations in Costa Rica. Forest Ecology and Management 99(1-2):43-54. https://doi. org/10.1016/S0378-1127(97)00193-X

Pham TD, Bui DT, Yoshino K and Le NN.2018. Optimized rule-based logistic model tree algorithm for mapping mangrove species using ALOS PALSAR imagery and GIS in the tropical region. Environmental earth sciences 77(5):159.

Pham TT, Vu TP, Pham DC, Dao LHT, Nguyen VT, Hoang NVH, Hoang TL, Dao TLC and Nguyen DT. 2019. Opportunities and challenges for mangrove management in Vietnam: Lessons learned from Thai Binh, Quang Ninh and Thanh Hoa provinces. Occasional Paper 197. Bogor, Indonesia: CIFOR. 
Phan L. 2011. Tác dung của rừng ngâp mặn trong bối cảnh biến đổi khí hậu. Truy cập ngày 24/02/2020: https://stnmt.binhdinh.gov.vn/ mnewsdetail.php?newsid $=311 \&$ id $=42 \& n$ ewsid $=311$ \&id $=42$

[QCVN] Công ty CP Kỹ thuật Tiêu chuẩn QCVN Việt Nam. [Không có ngày]. TíNH CHẤT CỦA NƯỚC THẢI CÔNG NGHIẸP SẢN XUẤT THÉP ĐỐl VỚl MÔI TRƯỜNG. Truy cập ngày 02 tháng 6 năm 2020. https://qcvn.com.vn/ tinh-chat-cua-nuoc-thai-cong-nghiep-sanxuat-thep-doi-voi-moi-truong/.

Quốc hội Việt Nam. 2010. Luật số 57/2010/ QH12 của Quốc hội : LUẬT THUẾ BẢO VỆ MÔI TRUỜNG.

Quốc hội Việt Nam. 2017. Luật số 18/2017/QH14 của Quốc hôii: LUÂTTHỦY SẢN.

Regensburger B. 2004. Recuperação de áreas degradadas pela mineração de argila através da regularização topográfica, da adição de insumos e serrapilheira, e de atratores da fauna. Florianópolis, Brazil: Federal University of Santa Catarina. https://repositorio.ufsc.br/bitstream/ handle/123456789/86827/203549.pdf

Rodrigues RR, Martins SV and Barros LCD. 2004. Tropical rain forest regeneration in an area degraded by mining in Mato Grosso State, Brazil. Forest ecology and management 190(2-3):323-33. https://doi. org/10.1016/j.foreco.2003.10.023

Roitman I, Travassos LR and Azevedo JL. 1987. Tratado de microbiologia. São Paulo: Manole.

Salomons W, Kerdijk H, Van Pagee H, Klomp R and Schreur A. 1988. Behaviour and impact assessment of heavy metals in estuarine and coastal zones. In Metals in coastal environments of Latin America pp. 157-198. Springer, Berlin, Heidelberg.

Sarika PR and Chandramohanakumar N. 2008. Distribution of heavy metals in mangrove sediments of Cochin estuary. Research Journal of Chemistry and Environment 12(3):37-44.

Sasmito SD, Taillardat P, Clendenning JN, Cameron C, Friess DA, Murdiyarso D and Hutley LB. 2019. Effect of land-use and land-cover change on mangrove blue carbon: A systematic review. Global change biology 25(12): 4291-302.

Sekabira K, Origa HO, Basamba TA, Mutumba $\mathrm{G}$ and Kakudidi E. 2010. Assessment of heavy metal pollution in the urban stream sediments and its tributaries. International journal of environmental science \& technology 7(3): 435-46.

Soares M and Casagrande J. 2007. Fitorremediação como estratégia de recuperação de solos degradados em áreas mineradas. In Barbosa LM and Santos Júnior NA, eds. A Botânica no Brasil: pesquisa, ensino e políticas públicas ambientais. São Paulo: Sociedade Botânica do Brasil. 529-33.

Sommerville M. 2016. Mangrove payment for environmental services in Vietnam: Opportunities \& challenges. Washington, DC: USAID Tenure and Global Climate Change Program. Truy cập ngày 02 tháng 6 năm 2020. https://www.land-links.org/wpcontent/uploads/2018/02/USAID_LAND_ TENURE_TGCC_MANGROVE_PAYMENT_ VIETNAM.pdf.

Souza CA, Gallardo ALCF, SILVA ÉDD, MELLO YCD, Righi CA and Solera ML. 2016. Environmental services associated with the reclamation of areas degraded by mining: potential for payments for environmental services. Ambiente \& sociedade 19(2):13768.

Souza EAD. 2007. Potencial de cianobactérias para a biorremediação de águas e solos contaminados por arsênio. Viçosa, Brazil: Federal University of Viçosa. https://www.locus.ufv.br/bitstream/ handle/123456789/2500/texto\%20 completo.pdf

Sở Khoa học và Công nghệ Bình Dương. 2014. Báo cáo khoa học tổng kết đề tài "Nghiên cứu đánh giá hiện trạng và dự báo phát thải các khí nhà kinh tại Bình Dương và đề xuất các giải pháp giảm thiểu".

Sở Nông nghiệp và Phát triển nông thôn Hải Phòng. 2019. Báo cáo về công tác tác quản lý bảo vệ rừng ven biển và thực hiện chính sách chi trả dịch vụ rừng. Báo cáo ngày 08/08/2019. Hải Phòng: Ủy ban nhân dân Tp. Hải Phòng.

Sprocati AR, Alisi C, Segre L, Tasso F, Galletti $M$ and Cremisini C. 2006. Investigating heavy metal resistance, bioaccumulation and metabolic profile of a metallophile microbial consortium native to an abandoned mine. Science of the total environment 366(2-3):649-58. https://doi. org/10.1016/j.scitotenv.2006.01.025 
Standard Chartered Bank. 2012. Standard Chartered (Vietnam) Acts For Vietnam Green. Truy cập ngày 02 tháng 6 năm 2020. https://www.sc.com/global/av/vn-scb-acts4-vietnam-green.pdf.

Tài nguyên và Môi trường. 2018a. Hải Phòng: Cảng cá, bến Cá bị sa bồi, xuống cấp, ô nhiếm môi trường. Truy cập ngày 02 tháng 6 năm 2020. https://baotainguyenmoitruong. $\mathrm{vn}$ /hai-phong-cang-ca-ben-ca-bi-sa-boixuong-cap-o-nhiem-moi-truong-239167. html.

Tài nguyên và Môi trường. 2018b. Hải Phòng: Lại "nóng" vấn đề môi trường trên vịnh Cát Bà. Truy cập ngày 02 tháng 6 năm 2020. https://baotainguyenmoitruong.vn/haiphong-lai-nong-van-de-moi-truong-trenvinh-cat-ba-248951.html

Tam NF, Li SH, Lan CY, Chen GZ, Li MS and Wong YS. 1995. Nutrients and heavy metal contamination of plants and sediments in Futian mangrove forest. Hydrobiologia 295(1-3): 149-58.

Tam NFY and Wong YS. 1993. Retention of nutrients and heavy metals in mangrove sediment receiving wastewater of different strengths. Environmental Technology 14(8):719-29.

Tam NFY and Wong YS. 1996. Retention and distribution of heavy metals in mangrove soils receiving wastewater. Environmental Pollution 94(3): 283-91.

Tam NFY and Wong YS. 2000. Spatial variation of heavy metals in surface sediments of Hong Kong mangrove swamps. Environmental Pollution 110: 195-205.

Tạp chí giao thông. 2019. Xây dựng, phát triển cảng biển xanh tại Việt Nam. Truy cập ngày 02 tháng 6 năm 2020. http://mt.gov.vn/vn/ tin-tuc/62285/xay-dung--phat-trien-cangbien-xanh-tai-viet-nam.aspx.

Tổng Công ty Bảo đảm an toàn hàng hải miền Bắc. 2009. Thông báo số $296 / T B H H-C T$. BĐATHH I ngày 04/12/2009 về việc các tàu thi công nạo vét duy tu luông Hải Phòng. Truy cập ngày 02 tháng 6 năm 2020. https:// vms-north.vn/thong-bao-hang-hai-247/ hai-phong-253/ve-viec-cac-tau-thi-congnao-vet-duy-tu-luong-hai-phong-3119-2. html.

Tổng công ty tư vấn và thiết kế GTVT - CTCP. 2015. Rà soát, cập nhật điều chỉnh quy hoạch chi tiết nhóm cảng biển phía bắc đến năm 2020, định hướng đến năm 2030 có tại http://www.vinamarine.gov.vn/sites/ default/files/Thuyet\%20minh\%20QH $\% 20$ N1.pdf

The Guardian. 2019. Empty North Sea gas fields to be used to bury $10 \mathrm{~m}$ tonnes of $\mathrm{CO} 2$.

Thông tin Công ty tại Hải Phòng. 2020. CÁC CÔNG TY SẢN XUÂT SĂT, THÉP, GANG TAII HẢI PHÒNG. https://hai-phong. congtydoanhnghiep.com/nganh-nghesan-xuat-sat-thep-gang

Thu M. 2018. Hải Phòng ra 'tối hậu thư' với công ty thép nhả khói độc ra môi trường. Truy cập ngày 02 tháng 6 năm 2020. https:// baotintuc.vn/thoi-su/hai-phong-ra-toihau-thu-voi-cong-ty-thep-nha-khoi-docra-moi-truong-20180106214714815.htm.

Thủ tướng Chính phủ. 2009. Quyết định số 2190/ QĐ TTg ngày 24 tháng 12 năm 2009 về việc phê duyệt Quy hoạch phát triển hệ thống cảng biển Việt Nam đến năm 2020, định hướng đến năm 2030.

Thủ tướng Chính phủ. 2014. Quyết định số 1037/QĐ-TTg ngày 24 tháng 06 năm 2014 về việc Phê duyệt điều chỉnh Quy hoạch phát triển hệ thống cảng biển Việt Nam đến năm 2020, định hướng đến năm 2030. http://vanban.chinhphu.vn/portal/ page/portal/chinhphu/hethongvanban? mode=detail\&document id=174573\&fbclid=IwAR2vqHVM_ $5 \mathrm{q} 1 \mathrm{yd} 07$ de2fWPbsQAzQYfzKBTKuM4feQc AejA2hDzz0DM1BLtk

Thủ tướng Chính phủ. 2014. Quyết định số 1517/ QD-TTG ngày 26 tháng 08 năm 2014 về việc phê duyệt Quy hoạch phát triển vận tải biển Việt Nam đến năm 2020, định hướng đến năm 2030.

Thủ tướng chính phủ. 2016. Quyết định số 403/ QĐ-TTg ngày 14 tháng 03 năm 2016 về việc phê duyệt điều chỉnh Quy hoạch phát triển ngành than Việt Nam đến năm 2020, có xét triển vọng đến năm 2030.

Thủ tướng Chính phủ. 2018. Quyết định số 821/ QĐ-TTg ngày 06 tháng 7 năm 2018: Phê duyệt điều chỉnh, bổ sung Quy hoạch tổng thể phát triển kinh tế - xã hội thành phố Hải Phòng đến năm 2025, định hướng đến năm 2030.

Thúy H. 2015. Dân bức xúc tố nước thải công ty thép VSC- POSCO và VINAPIPE gây ô nhiễm môi trường. Truy cập ngày 02 tháng 6 năm 2020. https://baotainguyenmoitruong.vn/ dan-buc-xuc-to-nuoc-thai-cong-ty-thep- 
vsc-posco-va-vinapipe-gay-o-nhiem-moitruong-269901.html.

Thùy H. 2019. "Ông lớn" trong ngành đóng tàu kêu khó. https://laodong.vn/kinh-te/ ong-lon-trong-nganh-dong-tau-keukho-758547.Ido

Trần P và Vũ H. 2018. Quy hoạch nuôi thủy sản tại Cát Bà: Không có chuyện đẩy dân đi. Dân Việt. Truy cập ngày 02 tháng 6 năm 2020. https://danviet.vn/quy-hoach-nuoi-thuysan-tai-cat-ba-khong-co-chuyen-daydan-di-7777868317.htm.

Trần TS và Đỗ DL. 2018. Phát triển kinh tế biển Hải Phòng trong bối cảnh hội nhập quốc tế: hiện trạng và tương lai. Tạp chí điện tử Bảo vệ Rừng và Môi trường. Truy cập ngày 02 tháng 6 năm 2020. https:// baovemoitruong.org.vn/phat-trien-kinh-tebien-hai-phong-trong-boi-canh-hoi-nhapquoc-te/.

Trần TS. 2018. Kinh tế biển Hải Phòng: Tăng trưởng quan trọng của vùng kinh tế bắc bộ trong chiến lược biển Việt Nam. Truy cập ngày 02 tháng 6 năm 2020. https:// biendao24h.vn/kinh-te-bien-hai-phongtang-truong-quan-trong-cua-vung-kinhte-bac-bo-trong-chien-luoc-bien-vietnam/.

[UNEP] United Nations Environment Programme. 2016. Global clean ports initiative.

Usman AR, Alkredaa RS and Al-Wabel MI. 2013. Heavy metal contamination in sediments and mangroves from the coast of Red Sea: Avicennia marina as potential metal bioaccumulator. Ecotoxicology and environmental safety 97: 263-70.

Ủy ban nhân dân thành phố Hải Phòng. 2015. BÁO CÁO KẾ HOACH PHÁT TRIỂN KINH TẾ-XÃ HÔI, QUỐC PHÖNG - AN NINH THÀNH PHỐ HẢI PHÒNG 5 NĂM 2016-2020.

Ủy ban nhân dân thành phố Hải Phòng. 2018. Quyết định số 32/2018/QĐ-UBND ngày 20/11/2018 ban hành quy chế quản lý hoạt động du lịch trên các vịnh thuộc quần đảo Cát Bà, huyện Cát Hải, thành phố Hải Phòng.

Ủy Ban Thường vụ Quốc hội. 2018. Nghị quyết số: 579/2018/UBTVQH14 ngày 26/09/2018 về biểu thuế bảo vệ môi trường.

Van der Werf GR, Morton DC, DeFries RS, Olivier JG, Kasibhatla PS, Jackson RB, Collatz GJ and Randerson JT. 2009. CO 2 emissions from forest loss. Nature geoscience 2(11): 737-8.
Vận tải đường biển. 2018. Phương thức vận chuyển đường biển. Truy cập ngày 02 tháng 6 năm 2020. https://vantaiduongbien. com.vn/phuong-thuc-van-chuyen-duongbien-325-26.html.

Vietnamnews. 2016. Quảng Ninh to stop transporting coal on highways. Truy cập ngày 02 tháng 6 năm 2020. https:// vietnamnews.vn/society/348498/quangninh-to-stop-transporting-coal-onhighways.html.

Vinhomes. 2019. Dựán Vinpearl Vũ Yên Hải Phòng của Vingroup ra mắt trong năm nay. Truy cập ngày 02 tháng 6 năm 2020. https:// vinhomecitys.com/du-an-vinpearl-vu-yenhai-phong-cua-vingroup-ra-mat-trong-namnay/.

VnExpress. 2001. S.O.S khói thải máy bay!. Truy cập ngày 02 tháng 6 năm 2020. https:// vnexpress.net/s-o-s-khoi-thai-maybay-1981872.html.

Vũ DT và Mai ST. 2006. Khả năng làm giảm độ cao của sóng tác động vào bờ biển của một số kiểu rừng ngập mặn trồng ở ven biển Hải Phòng. Tạp chí sinh học 28(2): 34-43.

Vũ DT. 2011. Vai trò của hai loại cấu trúc rừng ngập mặn trong việc cản bùn cát tác động phá hoạt bờ biển trong bão tại Bàng La (Đồ Sơn) và Đại Hợp (Kiến Thụy), Hải Phòng. Tạp chí sinh học 33(3): 51-7.

Wadt PGS. 2003. Práticas de conservação do solo e recuperação de áreas degradadas. Rio Branco: Embrapa Acre. https://www. infoteca.cnptia.embrapa.br/infoteca/ handle/doc/498802

Wolanski E and Mueller H. 1997. Currents and sediment transport in mangrove forests. Estuarine, Coastal and Shelf Science 4: 301-10.

Wood TS and Shelley ML. 1999. A dynamic model of bioavailability of metals in constructed wetland sediments. Ecological Engineering 12:231-52.

[WWF] World Wide Fund for Nature. 2006. Living Planet Report.

Yim MW and Tam NFY. 1999. "Effects of Wastewater-borne Heavy Metals on Mangrove Plants and Soil Microbial Activities. Marine pollution bulletin 32:17986.

Yoshihiro M, Michimasa M, Motohiko K and Phan NH. 1997. Mangroves as a coastal protection from waves in the Tong King delta, Vienam. Mangroves and Salt Marshes 1: 127-35. 
Yu KC, Tsai LJ, Chen SH and Ho ST. 2001. Chemical binding of heavy metals in anoxic river sediments. Water Research 35(17):4086-94.

Zhang Q, Bennett MT, Kannan K and Jin L. 2010. Payments for ecological services and eco- compensation: Practices and innovations in the People's Republic of China. Asian Development Bank. Truy cập ngày 02 tháng 6 năm 2020. https://www.adb.org/ sites/default/files/publication/27468/ payments-ecological-services-prc.pdf 


\section{Phụ lục}

\section{Phụ Lục 1. Danh sách các bến cảng tại Hải Phòng theo Quyết Định 616/QĐ- BGTंVTं Công Bố Danh Mục Bến Cảng Thuộc Các Cảng Biển Việt Nam}

\begin{tabular}{ll}
\hline STT & Tên bến cảng tại Hải Phòng \\
\hline 1 & Bến cảng Hải Phòng \\
\hline 2 & Bến cảng Vật Cách \\
\hline 3 & Bến cảng Đầu tư và phát triển cảng Đình Vũ \\
\hline 5 & Bến cảng Liên doanh phát triển Đình Vũ \\
\hline 6 & Bến cảng Xăng dầu Đình Vũ (19-9) \\
\hline 7 & Bến cảng Đoạn Xá \\
\hline 8 & Bến cảng Transvina \\
\hline 9 & Bến cảng Hải Đăng \\
\hline 10 & Bến cảng container Việt Nam (Viconship) \\
\hline 11 & Bến cảng Coủa Cấm \\
\hline 12 & Bến cảng Thủy sản II \\
\hline 13 & Bến cảng Thượng Lý \\
\hline 14 & Bến cảng Gas Đài Hải \\
\hline 15 & Bến cảng Total Gas Hải Phòng \\
\hline 16 & Bến cảng xăng dầu Petec Hải Phòng \\
\hline 17 & Bến cảng khí hóa lỏng Thăng Long \\
\hline 18 & Bến cảng đóng tàu Bạch Đằng \\
\hline 19 & Bến cảng Caltex \\
\hline 20 & Bến cảng công nghiệp tàu thủy Nam Triệu \\
\hline 21 & Bến cảng đóng tàu Phà Rừng \\
\hline 22 & Bến cảng Lilama Hải Phòng \\
\hline 23 & Bến cảng cá Hạ Long \\
\hline 24 & Bến cảng cơ khí Hạ Long \\
\hline 25 & Bến cảng dâuu K99 \\
\hline 26 & Bến cảng Biên Phòng \\
\hline 27 & Bến cảng Công ty 128 \\
\hline 28 & Bến cảng thiết bị vật tư Chùa Vẽ \\
\hline 30 & Bến cảng Đông Hải \\
\hline & Bến cảng Hải An \\
\hline
\end{tabular}




\begin{tabular}{ll}
\hline STT & Tên bến cảng tại Hải Phòng \\
\hline 31 & Bến cảng Tiến Mạnh \\
\hline 32 & Bến cảng tổng hợp Đình Vũ \\
\hline 33 & Bến cảng trang trí công ty 189 \\
\hline 34 & Bến cảng Công ty Sông Đà 12 (Tự Long) \\
\hline 35 & Bến cảng Nam Hải \\
\hline 36 & Bến cảng Công ty vận tải và cung ứng xăng dầu (Quỳnh Cư) \\
\hline 37 & Bến cảng DAP (hóa chất Việt Nam) \\
\hline 38 & Bến cảng PTSC Đình Vũ \\
\hline 39 & Bến cảng công ty Hóa dầu quân đội (Mipec) \\
\hline 40 & Bến cảng Công ty TNHH MTV 189 \\
\hline 41 & Bến cảng xăng dầu KCN Đình Vũ \\
\hline 42 & Bến cảng Công ty CP Dầu khí Hải Linh Hải Phòng \\
\hline 43 & Bến cảng Nam Hải Đình Vũ \\
\hline 44 & Bến cảng Nhà máy Nhiệt điện Hải Phòng \\
\hline 45 & Bến cảng container Vip Greenport \\
\hline 46 & Bến cảng Việt Nhật \\
\hline 47 & Bến cảng Nam Ninh \\
\hline 48 & Bến cảng chuyên dùng rau quả, thực phẩm tổng hợp Hùng Vương \\
\hline 49 & Bến cảng Nam Đình Vũ \\
\hline
\end{tabular}

Nguồn: QUYẾT ĐịnH 616/QĐ-BGTVT CÔNG BỐ DANH MỤC BẾN CẢNG THUộC CÁC CẢNG BIỂN VIỆT NAM 


\section{Phụ lục 2. Danh sách các công ty khai thác khoáng sản}

\begin{tabular}{|c|c|}
\hline STT & Các công ty khai thác khoáng sản \\
\hline & Quận Hải An \\
\hline 1 & Công Ty TNHH Đầu Tư Hoàng Sơn \\
\hline 2 & Công Ty TNHH Thương Mại Xây Dựng Xuất Nhập Khẩu Phú Quý \\
\hline 3 & Công Ty Cổ Phần Xây Dựng Công Trình Hàng Không Việt Nam \\
\hline 4 & CÔNG TYTNHH HƯNG TÚ \\
\hline 5 & Công Ty Cổ Phần Đông Đô Hải Phòng - Bqp \\
\hline 6 & CHI NHÁNH CÔNG TY CỔ PHẦN MINH PHÚ 689 TẠI HẢI PHÒNG \\
\hline 7 & CÔNG TY TNHH ĐẦU TƯ CÔNG TRİNH VÀ THƯđ̛́NG MẠI HOÀNG PHÁT - CHI NHÁNH HẢI AN \\
\hline 8 & $\begin{array}{l}\text { CÔNG TY TNHH MỘT THÀNH VIÊN KINH DOANH KHAI THÁC VẬT LIỆU XÂY DỰNG SAO ĐỎ - CHI NHÁNH HẢI } \\
\text { PHÒNG }\end{array}$ \\
\hline \multirow[t]{2}{*}{9} & CÔNG TY CỔ PHẦN CÔNG NGHỆ KHOÁNG SẢN HÀ NỘI VINCENT \\
\hline & Quận An Dương \\
\hline 10 & CÔNG TY CỔ PHẦN THƯƠNG MẠI VÀ KHAI THÁC KHOÁNG SẢN ĐA KIM PHÚ CƯỜNG \\
\hline 11 & Công Ty Cổ Phần Thương Mại Khai Thác Khoáng Sản Công Minh Quân \\
\hline 12 & Công ty cổ phần đầu tư và khai thác khoáng sản Phúc Song Quyền \\
\hline 13 & Công Ty Cổ Phần Sản Xuất \& Kinh Doanh Việt Đức \\
\hline 14 & Công Ty TNHH Đầu Tư Sản Xuất Và Thương Mại Việt Hoàng \\
\hline \multirow[t]{2}{*}{15} & Công ty trách nhiệm hữu hạn đầu tư sản xuất và thương mại Trung Nam \\
\hline & Huyện Cát Hải \\
\hline \multirow[t]{2}{*}{16} & Công Ty Cổ Phần Khai Thác Khoáng Sản Hải Đăng \\
\hline & Huyện Thủy Nguyên \\
\hline 17 & Công Ty Cổ Phần Khai Thác Khoáng Sản Thiên Lộc \\
\hline 18 & Công Ty Cổ Phần Thương Mại Và Khai Thác Khoáng Sản 468 Hải Phòng \\
\hline 19 & Công ty cổ phần khai thác chế biến khoáng sản Tiến Cường \\
\hline 20 & Công ty TNHH khai thác và chế biến khoáng sản Hải Long \\
\hline 21 & Liên hiệp hợp tác xã khai thác chế biến khoáng sản Cường Thịnh \\
\hline 22 & Công ty cổ phần xây dựng khai thác khoáng sản Hùng Anh \\
\hline 23 & Công Ty Cổ Phần Khai Thác Chế Biến Khoáng Sản Hải Phòng \\
\hline 24 & Công Ty TNHH Khai Thác Và Chế Biến Khoáng Sản Bảo Thịnh \\
\hline 25 & Công Ty Cổ Phần Đầu Tư Khai Thác Khoáng Sản Và Dịch Vụ Vận Tải Hải Phòng \\
\hline 26 & Công Ty Cổ Phần Khai Thác Và Chế Biến Đá Thuận An \\
\hline 27 & Doanh nghiệp tư nhân khai thác đá Đại Việt \\
\hline 28 & Hợp tác xã khai thác đá Minh Tân \\
\hline 29 & Hợp tác xã khai thác đá Tràng kênh \\
\hline 30 & Công ty trách nhiệm hữu hạn khai thác chế biến đá Phú Cường \\
\hline 31 & Công Ty Cổ Phần Khai Thác Và Chế Biến Đá Thuận An \\
\hline 32 & Chi Nhánh Số 1 Công Ty Cổ Phần Cung ứng Vật Tư Tiến Thành \\
\hline 33 & CÔNG TY CỔ PHẦN KHAI THÁC KHOÁNG SẢN KIÊN NGỌC \\
\hline \multirow[t]{2}{*}{34} & Công Ty TNHH Sản Xuất Trung Đức \\
\hline & Quận Lê Chân \\
\hline 35 & CÔNG TY CỔ PHẦN XÂY DỰNG KHAI THÁC KHOÁNG SẢN HƯNG PHÁT \\
\hline 36 & $\begin{array}{l}\text { CÔNG TY CỔ PHẦN ĐÂU TU THƯđ̛́NG MẠI XÂY DỰNG XUẤT NHẬP KHẨU KHAI THÁC KHOÁNG SẢN THÀNH } \\
\text { PHÁT }\end{array}$ \\
\hline
\end{tabular}




\begin{tabular}{|c|c|}
\hline STT & Các công ty khai thác khoáng sản \\
\hline \multirow[t]{2}{*}{37} & Công Ty Cổ Phần Khai Thác Khoáng Sản Điền Phát \\
\hline & Quận Hồng Bàng \\
\hline 38 & Công Ty Cổ Phần Xây Dựng Và Khai Thác Khoáng Sản Nam Đình Vũ \\
\hline 39 & Công Ty TNHH Khoáng Sản Bình Sơn \\
\hline 40 & Công Ty Cổ Phần Khoáng Sản An Bình \\
\hline \multirow[t]{2}{*}{41} & CÔNG TY TNHH KHAI THÁC KHOÁNG SẢN MINH ĐĂNG \\
\hline & Quận Ngô Quyền \\
\hline 42 & CÔNG TY TNHH KHAI THÁC KHOÁNG SẢN VÀ XÂY DỰNG VIẸT HÀ \\
\hline 43 & CÔNG TY CỔ PHẦN THƯƠNG MẠI DỊCH VỤ SAN LẤP VÀ KHAI THÁC KHOÁNG SẢN VIẸT HÙNG \\
\hline 44 & CÔNG TY CỔ PHẦN ĐÂU TƯ KHAI THÁC KHOÁNG SẢN AN PHÚ \\
\hline \multirow[t]{2}{*}{45} & CÔNG TY CỔ PHẦN KHAI THÁC KHOÁNG SẢN NHẬT ANH 1079 \\
\hline & Huyện Vinh Bảo \\
\hline 46 & CÔNG TY TNHH XÂY DỰNG VÀ KHAI THÁC KHOÁNG SẢN TÂN HUY HOÀNG \\
\hline
\end{tabular}

Nguồn: Cơ sở dữ liệu Thông tin doanh nghiệp 2020. 


\section{Phụ lục 3. Danh sách các công ty, nhà máy chế biến, sản xuất gang thép}

\begin{tabular}{|c|c|c|c|}
\hline STT & Tên công ty & MST & Địa chỉ \\
\hline 1 & NHÀ MÁY ĐÚC ĐÔNNG HOA PHƯợNG & 0200147994-001 & $\begin{array}{l}\text { Đường Hùng Vương, Quận Hồng } \\
\text { Bàng }\end{array}$ \\
\hline 2 & CÔNG TY CỔ PHẦN THÉP VINAKANSAI & 0200489476 & $\begin{array}{l}\text { Km } 18 \text { Quốc lộ 5, Xã Lê thiện, Huyện } \\
\text { An Dương }\end{array}$ \\
\hline 3 & CÔNG TY CỔ PHÂN THÉP ĐİNH VŨ & 0200513633 & $\begin{array}{l}\text { Lô C1 Khu kinh tế Đình Vũ, Phường } \\
\text { Đông Hải 2, Quận Hải An }\end{array}$ \\
\hline 4 & $\begin{array}{l}\text { CÔNG TY TRÁCH NHIỆM HỮU HẠN GANG } \\
\text { THÉP VẠN Lợl - HẢI PHÒNG }\end{array}$ & 0200563105 & $\begin{array}{l}\text { Thôn Song mai, Xã An hồng, Huyện } \\
\text { An Dương }\end{array}$ \\
\hline 5 & CÔNG TY TNHH KIÊN THỤC & 0200569241 & $\begin{array}{l}\text { Số 266A Đường Trần Nguyên Hãn, } \\
\text { Quận Lê Chân }\end{array}$ \\
\hline 6 & CÔNG TY TRÁCH NHIỆM HỮU HẠN MỸ HOA & 0200587956 & $\begin{array}{l}\text { Thôn Phương Mỹ, Xã Mỹ đồng, Huyện } \\
\text { Thuỷ Nguyên }\end{array}$ \\
\hline 7 & $\begin{array}{l}\text { CÔNG TY CỔ PHẦN ĐÚC KIM LOẠI-CO KHÍ VÀ } \\
\text { THƯƠNG MẠI DUY KHÁNH }\end{array}$ & 0200588170 & $\begin{array}{l}\text { Thôn Phương mỹ, Xã Mỹ đồng, Huyện } \\
\text { Thuỷ Nguyên }\end{array}$ \\
\hline 8 & $\begin{array}{l}\text { CÔNG TY CỔ PHẦN ĐÚC KIM LOẠI VÀ CƠ KHÍ } \\
\text { TìNH NHÀN }\end{array}$ & 0200588188 & $\begin{array}{l}\text { Thôn Phương mỹ, Xã Mỹ đồng, Huyện } \\
\text { Thuỷ Nguyên }\end{array}$ \\
\hline 9 & $\begin{array}{l}\text { CÔNG TY TRÁCH NHIỆM HỮU HẠN THƯđ̛́NG } \\
\text { MẠI DŨNG TÀI }\end{array}$ & 0200612909 & $\begin{array}{l}\text { Xóm } 6 \text { Thôn Do nha, Xã Tân tiến, } \\
\text { Huyện An Dương }\end{array}$ \\
\hline 10 & CÔNG TY CỔ PHẦN AN HUY & 0200635649 & $\begin{array}{l}\text { Số } 12 \text { Tổ } 9 \text { Khu 6, Phường Quán toan, } \\
\text { Quận Hồng Bàng }\end{array}$ \\
\hline 11 & $\begin{array}{l}\text { CÔNG TY CỔ PHẦN THÉP THĂNG LONG } \\
\text { KANSAI }\end{array}$ & 0200697758 & $\begin{array}{l}\text { Km18 Quốc lộ 5, Xã Lê Thiện, Huyện } \\
\text { An Dương }\end{array}$ \\
\hline 12 & CÔNG TY CỔ PHẦN THÉP VẠN LợI - VINASHIN & 0200697853 & $\begin{array}{l}\text { Thôn Song mai, Xã An hồng, Huyện } \\
\text { An Dương }\end{array}$ \\
\hline 13 & CÔNG TY CỔ PHẦN LUYỆN GANG VẠN LợI & 0200730677 & $\begin{array}{l}\text { Thôn Song Mai, Xã An Hồng, Huyện } \\
\text { An Dương }\end{array}$ \\
\hline 14 & $\begin{array}{l}\text { CÔNG TY CỔ PHẦN THƯƠNG MẠI QUANG } \\
\text { TÜNG }\end{array}$ & 0200733237 & $\begin{array}{l}\text { Thôn Kinh giao, Xã Tân tiến, Huyện } \\
\text { An Dương }\end{array}$ \\
\hline 15 & CÔNG TY CỔ PHẦN THÉP VẠN LỢI & 0200733540 & $\begin{array}{l}\text { Thôn Song Mai, Xã An Hồng, Huyện } \\
\text { An Dương }\end{array}$ \\
\hline 16 & CÔNG TY CỔ PHẦN THƯƠNG MẠI - VẬN TẢI HP & 0200761516 & $\begin{array}{l}\text { Số } 7 \text { Lô } 4 \text { PG An đồng, Xã An đồng, } \\
\text { Huyện An Dương }\end{array}$ \\
\hline 17 & $\begin{array}{l}\text { CÔNG TY CỔ PHẦN ĐẦU TƯ THƯƠNG MẠI } \\
\text { HOÀNG AN }\end{array}$ & 0200772733 & $\begin{array}{l}\text { Xóm Đồng hải, Xã An hưng, Huyện } \\
\text { An Dương }\end{array}$ \\
\hline 18 & $\begin{array}{l}\text { CÔNG TY TRÁCH NHIỆM HỮU HẠN LIÊN HợP } \\
\text { KIM LOẠI TRUNG VIẸT }\end{array}$ & 0200787916 & $\begin{array}{l}\text { Số 27C Đường Điện Biên Phủ, } \\
\text { Phường Minh khai, Quận Hồng Bàng }\end{array}$ \\
\hline 19 & CÔNG TY TRÁCH NHIỆM HỮU HẠN THÀNH UY & 0200807908 & $\begin{array}{l}\text { Tổ } 3 \text { Đường } 208 \text { Thôn An dương, Xã } \\
\text { An đồng, Huyện An Dương }\end{array}$ \\
\hline 20 & $\begin{array}{l}\text { CÔNG TY CỎ PHÂN THƯƠNG MẠI SHENGLI } \\
\text { VIẸT NAM }\end{array}$ & 0200810795 & $\begin{array}{l}\text { Số 2B Đường Minh khai, P. Minh khai, } \\
\text { Quận Hông Bàng }\end{array}$ \\
\hline 21 & $\begin{array}{l}\text { CÔNG TY TRÁCH NHIỆM HŨU HẠN THÉP HST } \\
\text { VIỆT NAM }\end{array}$ & 0200826107 & $\begin{array}{l}\text { Lô đất CN } 3.2 \text { Khu công nghiệp Đình } \\
\text { Vũ, Quận Hải An }\end{array}$ \\
\hline 22 & $\begin{array}{l}\text { CHI NHÁNH THUỶ NGUYÊN - CÔNG TY CỔ } \\
\text { PHÂN ĐÂU TƯ VÀ THƯƠNG MẠI AN THẮNG }\end{array}$ & 0200831361-001 & $\begin{array}{l}\text { Số } 345 \text { Phố Mới, Xã Tân Dương, } \\
\text { Huyện Thuỷ Nguyên }\end{array}$ \\
\hline 23 & CÔNG TY CỔ PHẦN CÔNG NGHIỆP KIM HƯNG & 0200832157 & $\begin{array}{l}\text { Số } 177 \text { Phương mỹ, Xã Mỹ đông, } \\
\text { Huyện Thuỷ Nguyên }\end{array}$ \\
\hline 24 & $\begin{array}{l}\text { CÔNG TY CỔ PHẦN VẬN TẢI VÀ TIẾP VẬN Á } \\
\text { CHÂUU }\end{array}$ & 0200853950 & $\begin{array}{l}\text { Số 138A Khu nhà ở Nguyễn Trãi, } \\
\text { Phường Máy tơ, Quận Ngô Quyền }\end{array}$ \\
\hline 25 & $\begin{array}{l}\text { CÔNG TY TRÁCH NHIỆM HỮU HẠN DỊCH VỤ } \\
\text { THƯớNG MẠI GIANG LINH }\end{array}$ & 0200902767 & $\begin{array}{l}\text { Thôn Hoàng lâu, Xã Hồng phong, } \\
\text { Huyện An Dương }\end{array}$ \\
\hline 26 & $\begin{array}{l}\text { CÔNG TY TRÁCH NHIỆM HỮU HAN THƯƠNG } \\
\text { MẠI XUẤT NHẬP KHẨU TRUNG KIÊN }\end{array}$ & 0200908952 & $\begin{array}{l}\text { Số } 519 \text { Trần Nhân Tông, Phường Nam } \\
\text { sơn, Quận Kiến An }\end{array}$ \\
\hline
\end{tabular}




\begin{tabular}{|c|c|c|c|}
\hline STT & Tên công ty & MST & Địa chỉ \\
\hline 27 & CÔNG TY TNHH THIÊN LONG THUẦN YẾN & 0200997712 & $\begin{array}{l}\text { Thôn 4, Xã Mỹ Đồng, Huyện Thuỷ } \\
\text { Nguyên }\end{array}$ \\
\hline 28 & CÔNG TY CỔ PHẦN CƠ KHÍ HẢI SƠN & 0200998635 & $\begin{array}{l}\text { Tổ } 18 \text { Khu 2, Phường Lãm Hà, Quận } \\
\text { Kiến An }\end{array}$ \\
\hline 29 & $\begin{array}{l}\text { CÔNG TY TRÁCH NHIỀM HỮU HẠN ĐẦU TƯ } \\
\text { XÂY DỰNG VẬN TẢl VẦ DICCH VỤ DU LICCH THÁl } \\
\text { HƯNG }\end{array}$ & 0201010600 & $\begin{array}{l}\text { Xóm } 4 \text { Thôn Đào Yêu, Xã Hồng Thái, } \\
\text { Huyện An Dương }\end{array}$ \\
\hline 30 & $\begin{array}{l}\text { CÔNG TY TRÁCH NHIỆM HỮU HẠN CƠ KHÍ } \\
\text { ĐÚC ĐAI AN }\end{array}$ & 0201039046 & $\begin{array}{l}\text { Thôn 2, Xã Mỹ Đồng, Huyện Thuỷ } \\
\text { Nguyên }\end{array}$ \\
\hline 31 & $\begin{array}{l}\text { CÔNG TY CỔ PHẦN CƠ KHÍ VÀ THƯƠNG MẠI } \\
\text { HOȦNG TÜNG }\end{array}$ & 0201042786 & $\begin{array}{l}\text { Số 24/202 Tổ 3, khu Miếu hai xã, } \\
\text { Phường Dư Hàng Kênh, Quận Lề Châr }\end{array}$ \\
\hline 32 & $\begin{array}{l}\text { CÔNG TY TNHH MỘT THÀNH VIÊN CHẾ TAOO } \\
\text { THIÉT B! LUYỆN KIM CỬU LONG }\end{array}$ & 0201043797 & $\begin{array}{l}\text { Km } 9 \text { đường Hà nội, Phường Quán } \\
\text { Toan, Quận Hồng Bàng }\end{array}$ \\
\hline 33 & $\begin{array}{l}\text { CÔNG TY TRÁCH NHIỆM HỮU HẠN SẢN XUẤT } \\
\text { AN THUẤN PHÁT }\end{array}$ & 0201050603 & $\begin{array}{l}\text { Số } 136 \text { Lán bè, Phường Lam Sơn, } \\
\text { Quận Lê Chân }\end{array}$ \\
\hline 34 & $\begin{array}{l}\text { CÔNG TY CỔ PHẦN XÂY DỨNG VÀ THƯƠNG } \\
\text { MẠI CHÍ LINH }\end{array}$ & 0201063497 & $\begin{array}{l}\text { Thôn Minh Thị, Xã Toàn Thắng, Huyện } \\
\text { Tiên Lãng }\end{array}$ \\
\hline 35 & $\begin{array}{l}\text { CÔNG TY TRÁCH NHIỆM HỮU HẠN XÂY DỰNG } \\
\text { HƯNG HIẾU }\end{array}$ & 0201069530 & $\begin{array}{l}\text { Tổ dân phố Văn Tràng 1, Thị Trấn } \\
\text { Trường Sơn, Huyện An Lão }\end{array}$ \\
\hline 36 & $\begin{array}{l}\text { CÔNG TY TNHH THƯƠNG MẠI VÀ DICH VỤ } \\
\text { NGỌC TIẾN }\end{array}$ & 0201101939 & $\begin{array}{l}\text { Số } 49 \text { Khu Kiều Sơn, Phường Đằng } \\
\text { Lâm, Quận Hải An }\end{array}$ \\
\hline 37 & $\begin{array}{l}\text { CÔNG TY CỔ PHẦN THƯƠNG MẠI QUANG } \\
\text { PHONG }\end{array}$ & 0201114430 & $\begin{array}{l}\text { Số } 154 \text { đường 5/2, Phường Quán } \\
\text { Toan, Quận Hồng Bàng }\end{array}$ \\
\hline 38 & $\begin{array}{l}\text { CÔNG TY TNHH ĐẦU TƯ VÀ XÂY DỰNG TÂN } \\
\text { VIẸT PHÁT }\end{array}$ & 0201126429 & $\begin{array}{l}\text { Số } 695 \text { đường Nguyễn Văn Linh, } \\
\text { Phường Vĩnh Niệm, Quận Lê Chân }\end{array}$ \\
\hline 39 & $\begin{array}{l}\text { CÔNG TY TNHH THƯƠNG MẠI VÀ VẬN TẢI } \\
\text { NAM MẠNH }\end{array}$ & 0201129155 & $\begin{array}{l}\text { Số } 129 \text { ngõ } 280 \text { Tổ 21, Phường Niệm } \\
\text { Nghĩa, Quận Lê Chân }\end{array}$ \\
\hline 40 & $\begin{array}{l}\text { CÔNG TY TNHH ĐẦU TƯ VÀ VẬT LIỆU XÂY } \\
\text { DỰNG TÂN VIẸT PHÁT }\end{array}$ & 0201132214 & $\begin{array}{l}\text { Số } 695 \text { đường Nguyễn Văn Linh, } \\
\text { Phường Vinnh Niệm, Quận Lê Chân }\end{array}$ \\
\hline 41 & $\begin{array}{l}\text { CỐNG TY CỎ PHẦN ĐÚC KIM LOẠI VÀ } \\
\text { THƯỚNG MẠI TÂN DUY HƯNG }\end{array}$ & 0201227297 & $\begin{array}{l}\text { Thôn Sáu Phiên (tại nhà ông Trịnh Văr } \\
\text { Dần), Xã An Lư, Huyện Thuỷ Nguyên }\end{array}$ \\
\hline 42 & $\begin{array}{l}\text { CÔNG TY TNHH GANG THÉP CHUYÊN DỤNG } \\
\text { VIỆT NGA }\end{array}$ & 0201302466 & $\begin{array}{l}\text { Số } 367 \text { Tôn Đức Thắng, Xã An Đồng, } \\
\text { Huyện An Dương }\end{array}$ \\
\hline 43 & $\begin{array}{l}\text { CỐNG TY TNHH THÉP DONGBU VIỆT NAM } \\
0201303910\end{array}$ & 0201303910 & $\begin{array}{l}\text { Lô CN3.2A, CN3.2B, CN3.1C, Khu cônc } \\
\text { nghiệp Đình Vũ thuộc Khu, Phường } \\
\text { Đông Hải 2, Quận Hăi An }\end{array}$ \\
\hline 44 & CÔNG TY TNHH ĐIỆN CƠ KPT & 0201646259 & $\begin{array}{l}\text { Thôn 7, Xã Kiền Bái, Huyện Thuỷ } \\
\text { Nguyên }\end{array}$ \\
\hline 45 & $\begin{array}{l}\text { CÔNG TY CỔ PHẦN BÊ TÔNG VÀ XÂY DỰNG } \\
\text { GIA MINH - MINH ĐỨC } 2\end{array}$ & 0201650819 & $\begin{array}{l}\text { Thôn } 3 \text { + Thôn 4, Xã Gia Minh, Huyện } \\
\text { Thuỷ Nguyên }\end{array}$ \\
\hline 46 & CÔNG TY TNHH ĐẦU TƯ HƯNG PHÁT ĐẠT & 0201784403 & $\begin{array}{l}\text { Số 33A/571 Nguyễn Văn Linh, } \\
\text { Phường Kênh Dương, Quận Lê Chân }\end{array}$ \\
\hline 47 & $\begin{array}{l}\text { CÔNG TY CỔ PHẦN SẢN XUẤT VÀ THƯƠNG } \\
\text { MẠI THÉP HPS }\end{array}$ & 0201867963 & $\begin{array}{l}\text { Số 133A Lương Khánh Thiện, Phường } \\
\text { Cầu Đất, Quận Ngô Quyền }\end{array}$ \\
\hline 48 & CÔNG TY CỔ PHẦN THÉP DRAGON & 0201882231 & $\begin{array}{l}\text { Km } 9 \text { đường Hà Nội, Xã An Hồng, } \\
\text { Huyện An Dương }\end{array}$ \\
\hline 49 & $\begin{array}{l}\text { CÔNG TY CỔ PHẦN SẢN XUẤT THƯƠNG } \\
\text { MAII INOX NGUYỂN MINH - CHI NHÁNH HẢl } \\
\text { PHÖNG }\end{array}$ & 0307512470-001 & $\begin{array}{l}\text { Km 9, đường Hà Nội, Phường Quán } \\
\text { Toan, Quận Hồng Bàng }\end{array}$ \\
\hline 50 & $\begin{array}{l}\text { CHI NHÁNH CÔNG TY TNHH ĐÂU TƯ PHÁT } \\
\text { TRIẾN NAM THUẬN TẠI HẢI PHÒNG }\end{array}$ & 0311736755-001 & \\
\hline
\end{tabular}

Nguồn: Thông tin Công ty tại Hải Phòng 2020. 


Các báo cáo chuyên đề của CIFOR chuyển giao các kết quả nghiên cứu quan trọng đối với ngành lâm nghiệp. Nội dung của báo cáo đều được đánh giá bởi các chuyên gia trong và ngoài tổ chức.

Việc đánh giá tiềm năng chi trả dịch vụ môi trường do rừng ngập mặn đem lại đang trở nên vô cùng cấp thiết bởi điều này sẽ giúp nâng cao tổng thu PFES và nhận thức của các bên có liên quan về giá trị to lớn mà rừng ngập mặn đem lại cho các ngành nghề kinh tế, từ đó bảo vệ rừng ngập mặn hiệu quả hơn. Mặc dù vậy, xây dựng cơ chế chi trả dịch vụ môi trường rừng hiện nay gặp nhiều khó khăn do thiếu các thông tin liên quan đến việc “Chi trả cho dịch vụ nào? Ai là người chi trả? Mức chi trả là bao nhiêu? Thu chi như thế nào?" Việc trả lời 4 câu hỏi trên đòi hỏi phải có nhiều nghiên cứu được tiến hành bài bản trong một thời gian đủ dài. Báo cáo này nhằm trả lời cho 2 câu hỏi đầu tiên dựa vào trường hợp nghiên cứu điểm tại Hải Phòng. Báo cáo cho thấy Cơ chế chi trả dịch vụ môi trường rừng (PFES) đối với rừng ngập mặn tại Việt Nam có thể áp dụng với 8 loại dịch vụ môi trường chính: 1) Dịch vụ hấp thụ, lưu trữ, bể chứa các-bon; 2) Dịch vụ giảm bồi lắng và lượng bùn thải; 3) Dịch vụ chống xói lở bờ biển; 4) Dịch vụ chắn sóng; 5) Dịch vụ cung ứng nước sạch, lọc kim loại nặng và chất ô nhiễm; 6) Dịch vụ cung ứng bãi đẻ; 7) Dịch vụ vẻ đẹp cảnh quan; và 8) Dịch vụ cung cấp nguyên liệu thực phẩm. Kết quả nghiên cứu cũng chỉ rõ có 20 nhóm người mua dịch vụ môi trường rừng ngập mặn tiềm năng trên địa bàn Hải Phòng bao gồm: Công ty doanh nghiệp nạo vét, công ty năng lượng, ngành giải trí, ngành ngân hàng, ngành vận tải hàng không, cảng cá, cảng biển, khu kinh tế ven biển, công ty khai thác cát, ngành khai thác khoáng sản và luyện kim, ngành vận tải, ngành nhiệt điện, các nhóm quản lí đê điều, công ty du lịch, cộng đồng dân cư, công nghiệp đóng tàu, công ty sản xuất mặt hàng nông, lâm, thủy hải sản, công ty xăng dầu và công ty nước sạch. Trong khi một số nhóm người mua đã thể hiện cam kết cao cho việc tiến hành chi trả cần có thêm nhiều nghiên cứu trong tương lai để tìm hiểu mức sẵn lòng chi trả của các bên còn lại trong việc tham gia PFES.

\begin{tabular}{|c|c|c|}
\hline CGIAR & $\begin{array}{l}\text { RESEARCH } \\
\text { PROGRAM ON } \\
\text { Forests, Trees and } \\
\text { Agroforestry }\end{array}$ & $\begin{array}{l}\text { Chương trình nghiên cứu của CGIAR về Rừng, Cây gỗ và Nông lâm kết hợp (FTA) là chương trình phát } \\
\text { triển nghiên cứu lớn nhất thế giới nhằm nâng cao vai trò của rừng, cây gỗ và nông lâm kết hợp với } \\
\text { mục tiêu phát triển bền vững và đảm bảo lương thực để ứng phó với biến đổi khí hậu. CIFOR chủ trì } \\
\text { các nghiên cứu FTA trong mối quan hệ đối tác chiến lược với Bioversity International, CATIE, CIRAD, } \\
\text { INBAR, ICRAF và TBI. } \\
\text { Nahiên cứu này được hỗ trơ bởi Ouỹ đối tác CGIAR: cigar.ora/funders/ }\end{array}$ \\
\hline
\end{tabular}
nghiên cứu sáng tạo, nâng cao năng lực của các bên đối tác, tích cực tham gia đối thoại với các bên liên quan để hỗ trợ định hình chính sách và thực tiễn tác động tới rừng và con người. CIFOR là tổ chức nghiên cứu thuộc liên minh CGIAR và chủ trì các chương trình nghiên cứu của CGIAR về Rừng, Cây gỗ và Nông lâm kết hợp (FTA). Trụ sở chính của CIFOR đặt tại Bogor, Indonesia và các văn phòng của CIFOR có mặt tại Nairobi, Kenya; Yaounde, Cameroon; Lima, Peru và Bonn, Germany. 